\title{
Article
}

\section{Design, Synthesis, and Evaluation of Novel 3-Carboranyl-1,8-Naphthalimide Derivatives as Potential Anticancer Agents}

\author{
Sebastian Rykowski ${ }^{1}$, Dorota Gurda-Woźna ${ }^{2,+} \oplus$, Marta Orlicka-Płocka ${ }^{2,+}$, Agnieszka Fedoruk-Wyszomirska ${ }^{2}{ }^{\circledR}$, \\ Małgorzata Giel-Pietraszuk ${ }^{2}$, Eliza Wyszko ${ }^{2}$, Aleksandra Kowalczyk ${ }^{3}{ }^{\circ}$, Paweł Stączek ${ }^{3}{ }^{\circ}$, Andrzej Bak ${ }^{4}{ }^{(0}$, \\ Agnieszka Kiliszek ${ }^{2}$, Wojciech Rypniewski ${ }^{2}$ a and Agnieszka B. Olejniczak ${ }^{1, *} \mathbb{D}$
}

Citation: Rykowski, S.; GurdaWoźna, D.; Orlicka-Płocka, M.; Fedoruk-Wyszomirska, A.; GielPietraszuk, M.; Wyszko, E.; Kowalczyk, A.; Stączek, P.; Bak, A.; Kiliszek, A.; et al. Design, Synthesis, and Evaluation of Novel 3-Carboranyl1,8-Naphthalimide Derivatives as Potential Anticancer Agents. Int. J. Mol. Sci. 2021, 22, 2772. https:// doi.org/10.3390/ijms22052772

Academic Editor: Giovanni Natile

Received: 18 February 2021

Accepted: 6 March 2021

Published: 9 March 2021

Publisher's Note: MDPI stays neutral with regard to jurisdictional claims in published maps and institutional affiliations.

Copyright: (c) 2021 by the authors Licensee MDPI, Basel, Switzerland. This article is an open access article distributed under the terms and conditions of the Creative Commons Attribution (CC BY) license (https:// creativecommons.org/licenses/by/ $4.0 /$ )
1 Institute of Medical Biology, Polish Academy of Sciences, 106 Lodowa St., 93-232 Lodz, Poland; srykowski@cbm.pan.pl

2 Institute of Bioorganic Chemistry, Polish Academy of Sciences, 12/14 Z. Noskowskiego St., 61-704 Poznan, Poland; d_gurda@ibch.poznan.pl (D.G.-W.); mplocka@ibch.poznan.pl (M.O.-P.); agaw@ibch.poznan.pl (A.F.-W.); giel@ibch.poznan.pl (M.G.-P.); wyszkoe@ibch.poznan.pl (E.W.); kiliszek@ibch.poznan.pl (A.K.); wojtekr@ibch.poznan.pl (W.R.)

3 Department of Molecular Microbiology, Faculty of Biology and Environmental Protection, University of Lodz, 12/16 Banacha St., 90-237 Lodz, Poland; aleksandra.strzelczyk@biol.uni.lodz.pl (A.K.); pawel.staczek@biol.uni.lodz.pl (P.S.)

4 Department of Chemistry, University of Silesia, 9 Szkolna St., 40-007 Katowice, Poland; andrzej.bak@us.edu.pl

* Correspondence: aolejniczak@cbm.pan.pl; Tel.: +48-42-272-36-37

+ Equal contribution.

\begin{abstract}
We synthesized a series of novel 3-carboranyl-1,8-naphthalimide derivatives, mitonafide and pinafide analogs, using click chemistry, reductive amination and amidation reactions and investigated their in vitro effects on cytotoxicity, cell death, cell cycle, and the production of reactive oxygen species in a HepG2 cancer cell line. The analyses showed that modified naphthalic anhydrides and naphthalimides bearing ortho- or meta-carboranes exhibited diversified activity. Naphthalimides were more cytotoxic than naphthalic anhydrides, with the highest $\mathrm{IC}_{50}$ value determined for compound $9(3.10 \mu \mathrm{M})$. These compounds were capable of inducing cell cycle arrest at G0/G1 or G2M phase and promoting apoptosis, autophagy or ferroptosis. The most promising conjugate 35 caused strong apoptosis and induced ROS production, which was proven by the increased level of 2'-deoxy-8-oxoguanosine in DNA. The tested conjugates were found to be weak topoisomerase II inhibitors and classical DNA intercalators. Compounds 33, 34, and 36 fluorescently stained lysosomes in HepG2 cells. Additionally, we performed a similarity-based assessment of the property profile of the conjugates using the principal component analysis. The creation of an inhibitory profile and descriptor-based plane allowed forming a structure-activity landscape. Finally, a ligand-based comparative molecular field analysis was carried out to specify the (un)favorable structural modifications (pharmacophoric pattern) that are potentially important for the quantitative structure-activity relationship modeling of the carborane-naphthalimide conjugates.
\end{abstract}

Keywords: naphthalimides; carborane; anticancer activity

\section{Introduction}

1,8-Naphthalimides are a class of polycyclic imides consisting of $\pi$-deficient flat aromatic or heteroaromatic ring systems. These compounds have been used in biological and nonbiological applications and have mainly been tested as DNA intercalators and anticancer as well as antibacterial, antiviral, and analgesic agents [1]. They exert their antitumor activity through the inhibition of topoisomerase I/II enzymes, photoinduced DNA damage, induction of reactive oxygen species (ROS) production, and malfunctions of lysosome and mitochondria [2], receptor tyrosine kinases [3], and DNA and RNA 
synthesis [4]. Most of the naphthalimides exhibit fluorescence and are thus widely used in biological imaging [5], as fluorescent probes for the targeted sensing of ions [6], endogenous molecules [7], and cancer cells [8].

Among the most promising and well-described naphthalimides are mitonafide, pinafide, amonafide, and elinafide, which exhibit excellent antitumor activity. Mitonafide, amonafide, and elinafide have entered phase II clinical trials. Despite their effectiveness, the latter two are no longer in clinical trials due to unpredicted toxicity caused by one of their metabolites, $\mathrm{N}$-acetylamonafide, and neuromuscular dose-limiting toxicity, respectively [1,9]. The discovery, development, and structure-activity relationships (SARs) of 1,8-naphthalimide derivatives as anticancer agents were summarized by Tandon et al. [10] and Tomczyk et al. [9] in their works. It has been revealed that the modification of the naphthalimide backbone at different positions (especially positions 3 and 4) had remarkable effects on the anticancer activity, DNA binding properties and spectroscopic properties of the compounds [11].

The biomedical application of carboranes $\left(\mathrm{C}_{2} \mathrm{~B}_{10} \mathrm{H}_{12}\right)$ (Figure 1) has been reviewed in several papers [12-19], particularly focusing on their properties that may be of importance in the design of biologically active compounds, which include the following: their ability of unique noncovalent interactions (ionic interaction, $\sigma$-hole interaction, dihydrogen bond formation); spherical or ellipsoidal geometry and rigid three-dimensional (3D) arrangement (which offer versatile platforms for 3D molecular construction); lipophilicity, amphiphilicity, or hydrophilicity (depending on the type of boron cluster used which allows modulating the pharmacokinetics and bioavailability); chemical stability as well as susceptibility to functionalization; bioorthogonality; stability in biological environments; abiotic origin; and high content of boron (important for boron neutron capture therapy, BNCT).

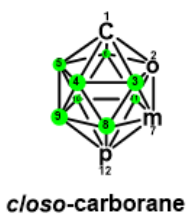

1,2-ortho (o); 1,7-meta (m); 1,12-para (p)

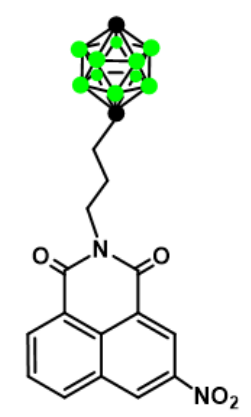

$N$-[3-(1,12-dicarba-closo-dodecaborane-1-yl)propyl] -1,8-naphthalimide

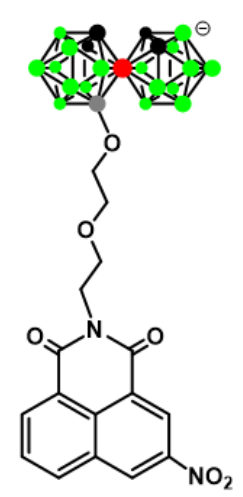

$N$-[8-(3-oxa-pentoxy)-3,3'-commo-bis(1,2-dicarba-3-cobalta(III)-closo- $\quad N$-\{ $\{2-(3,3$ '-commo-bis(1,2-dicarba-3dodecabolte)]-lobata(III)-closo- cobalta(III)-closo-dodecaborate-1-yl)ethyl]

-dodecaborate)]-1,8-naphthalimide $\quad 1^{\prime}$-aminoethyl)\}-1,8-naphthalimide

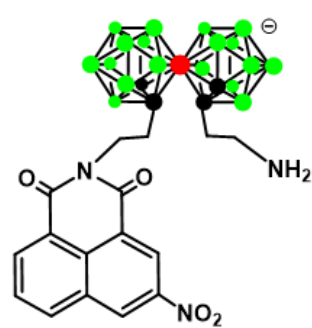

$\boldsymbol{D} \mathrm{C}$ or $\mathrm{CH}, \ominus=\mathrm{BH}, \ominus=\mathrm{B}, \ominus=\mathrm{C} \circ$

Figure 1. General structure of icosahedral dicarba-closo-dodecaborane (closo-carborane, $\mathrm{C}_{2} \mathrm{~B}_{10} \mathrm{H}_{12}$ ), and example structures of naphthalimides with boron cluster [20].

In our recent work, we described the methods used for the synthesis of naphthalimides modified with carborane or metallacarborane groups, as analogs of mitonafide (Figure 1). The cytotoxic properties of the obtained conjugates were investigated in the human cancer cell lines HepG2 and RPMI 2650, and the results showed that the type of boron cluster 
affected the various cytotoxic activities of the tested compounds. Moreover, flow cytometry analysis indicated that the naphthalimide boron cluster conjugate could effectively induce cell cycle arrest at G0/G1 phase and promote mainly apoptosis in the HepG2 cell line. However, the studied compounds were found to be rather weak classical DNA intercalators, compared to mitonafide, which indicates other types of interaction with DNA [20].

Based on the above results, we continued our research, and in this paper, we describe a method for synthesizing naphthalimide derivatives, containing 1,2-dicarba-closo- dodecaborane (ortho-carborane) or 1,7-dicarba-closo-dodecaborane (meta-carborane) at position 3 of the heteroaromatic skeleton, to investigate their anticancer activity and ability to induce cell death, cell cycle arrest, ROS production, and inhibition of human topoisomerase II $\alpha$. Studies on calf-thymus DNA (ct-DNA) were performed to evaluate the interaction of the synthesized derivatives with DNA. Additionally, we carried out a SAR-mediated similarity assessment of the property profile of the conjugates containing carborane group.

\section{Results and Discussion}

\subsection{Chemistry}

\subsubsection{Synthesis of Mitonafide and Pinafide Analogs Containing Carborane Clusters}

The novel naphthalimide derivatives containing carborane clusters described in this study (compounds 8-11, 17-20, 27-30, 33-36, 39-42, Figures 2-5) were synthesized using the following methods: (1) copper(I)-catalyzed Huisgen-Meldal-Sharpless 1,3-dipolar cycloaddition of azides and alkynes (i.e., click chemistry) (Schemes 1 and 2); (2) reductive amination (Scheme 3); and (3) amidation reactions (Scheme 4).

Click chemistry is a very efficient and popular method to modify molecules [21,22]. Naphthalimide-carborane conjugates were synthesized via click chemistry using a standard procedure involving three steps. In the first step, suitable boron cluster donors $(4,5)[23]$ were dissolved in a mixture of THF and water. In the second step, a naphthalic anhydride containing a terminal triple bond $(\mathbf{3}, \mathbf{1 4}$, Schemes 1 and 2), a catalytic amount of sodium ascorbate, and $\mathrm{CuSO}_{4} \cdot 5 \mathrm{H}_{2} \mathrm{O}$ were added, and the reactions were performed at $35^{\circ} \mathrm{C}$ for $2-4 \mathrm{~h}$. After purification, modified anhydrides $(6,7,15,16$, Schemes 1 and 2$)$ were obtained in yields ranging between $48 \%$ and $74 \%$, with the lower yield for derivatives modified with meta-carborane. In the third step, the modified naphthalic anhydrides were transformed to mitonafide and pinafide analogs via a nucleophilic reaction with appropriate amine. The yield of the products 8-11 and 17-20 (Schemes 1 and 2) achieved after isolation and purification by column chromatography was in the range of $41-84 \%$. The modified anhydrides 6, 7, 15, and 16, as well as modified naphthalimides 8-11 and 17-20, were characterized by ${ }^{1} \mathrm{H}-,{ }^{13} \mathrm{C}-$, and ${ }^{11} \mathrm{~B}-\mathrm{NMR}, \mathrm{FT}-\mathrm{IR}, \mathrm{MS}$, RP-HPLC (Figures S1-S86 (Electronic Supplementary Information, ESI)), and TLC.

It is worth adding that products 8-11 can be directly synthesized from mitonafide or pinafide derivatives bearing terminal triple bonds with boron cluster donors 4, 5, especially in the presence of tris[((1-benzyl)-1H-1,2,3-triazol-4yl)methyl]amine (TBTA) as a ligand to complex and "protect" copper(I) [24]. However, an advantage of the synthetic pathway described above is that one substrate (the anhydride 6 or 7) gives rise to two target productsmitonafide and pinafide analogs.

Due to its synthetic merits as well as the ubiquitous presence of amines among biologically active compounds, reductive amination plays a dominant role in pharmaceutical and medicinal chemistry. It is characterized by operational ease and a wide toolbox of protocols and hence is considered one of the key approaches to $\mathrm{C}-\mathrm{N}$ bond construction [25]. 
<smiles></smiles>

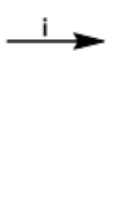<smiles>[R7]CCCn1cc(-c2cc3c4c(cccc4c2)C(=O)N([R2])C3=O)nn1</smiles>

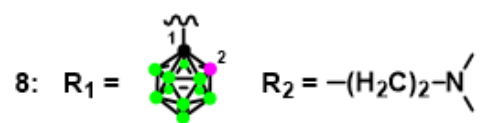

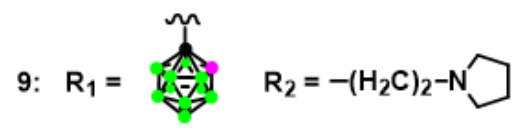

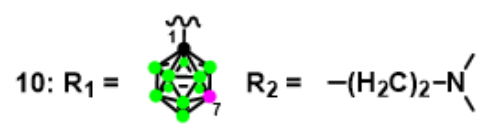

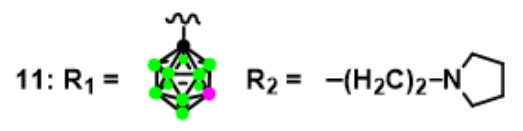

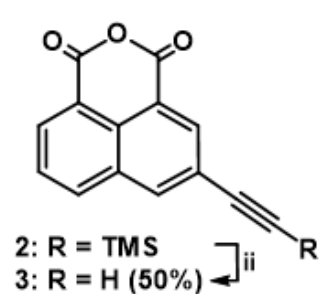<smiles>[R7]CCCn1cc(-c2cc3c4c(cccc4c2)C(=O)OC(=O)O3)nn1</smiles>

Scheme 1. Synthesis of naphthalimide-ortho-/meta-carborane conjugates 8-11. Reagents and Conditions: (i) $\mathrm{HCCSi}\left(\mathrm{CH}_{3}\right)_{3}, \mathrm{Pd}\left(\mathrm{PPh}_{3}\right)_{4}, \mathrm{CuI}, \mathrm{DMF}, \mathrm{TEA}, 2 \mathrm{~h}, 65^{\circ} \mathrm{C}$; (ii) TFA, $\mathrm{H}_{2} \mathrm{O}, \mathrm{THF}, 8 \mathrm{~h}$, room temperature (RT); (iii) 1-(3-azidopropyl)-1,2-dicarba-closo-dodecaborane (4), $\mathrm{CuSO}_{4} \cdot 5 \mathrm{H}_{2} \mathrm{O}$, sodium ascorbate, $\mathrm{THF} / \mathrm{H}_{2} \mathrm{O}, 4 \mathrm{~h}, 35{ }^{\circ} \mathrm{C}$ (for 6); 1-(3-azidopropyl)-1,7-dicarba-closo-dodecaborane (5), $\mathrm{CuSO}_{4} \cdot 5 \mathrm{H}_{2} \mathrm{O}$, sodium ascorbate, and THF $/ \mathrm{H}_{2} \mathrm{O}, 2 \mathrm{~h}, 35^{\circ} \mathrm{C}$ (for 7); (iv) $\mathrm{N}, \mathrm{N}$-dimethylethylenediamine (for 8 and 10), $\mathrm{N}$-(2-aminoethyl)pyrrolidine (for 9 and 11), EtOH, $1 \mathrm{~h}, 35^{\circ} \mathrm{C}$ and then $1 \mathrm{~h}, 45^{\circ} \mathrm{C}$. The yields of the compounds are given in parentheses.

Treatment of 3-amino-1,8-naphthalic anhydride (12) [26], 3-amino- $\mathrm{N}-[2-($ dimethylamino)ethyl]-1,8-naphthalimide (21), or 3-amino- $N$-[2-(N-pyrrolidinyl)ethyl]-1,8-naphthalimide (22) $[26,27]$ with an appropriate aldehyde containing ortho-carborane (23) or meta-carborane (24) [28] in anhydrous THF or MeOH at $65-70{ }^{\circ} \mathrm{C}$ under an inert (Ar) atmosphere resulted in the corresponding Schiff bases $25-30$, but these could not be isolated due to their instability (Scheme 3). Compounds 31-36 were obtained by treating the modified Schiff bases 25-30 witH- $\mathrm{NaBH}_{3} \mathrm{CN}$, followed by column chromatography.

Decaborane $\left(\mathrm{B}_{10} \mathrm{H}_{14}\right)$, one of the principal boron hydride clusters, has been reported as a mild reducing agent. It is quite stable, easy to handle, and can be effortlessly removed after reaction [29]. The decaborane cluster is used in various types of reactions, such as reductive amination of aldehydes [30], reductive etherification [31], or even one-pot reduction/reductive amination witH-Nitro compounds [32]. It has been reported that the synthesis of compounds $\mathbf{3 2}, \mathbf{3 5}$, and $\mathbf{3 6}$ modified with an ortho-/meta-carborane cluster was carried out using decaborane as a reducing agent, which resulted in an expected product with a lower or similar yield compared to that obtained from the reaction using $\mathrm{NaBH}_{3} \mathrm{CN}$. 
Therefore, this method was not included in the Materials and Methods section in this paper. The structure, purity, and homogeneity of compounds $31-36$ were confirmed by ${ }^{1} \mathrm{H}-,{ }^{13} \mathrm{C}-$, and ${ }^{11}$ B-NMR, FT-IR, MS, RP-HPLC (Figures S87-S129 (ESI)), and TLC.

Formation of amide bonds is one of the most frequently encountered reactions in the synthesis of biologically active compounds [33]. We developed methods for synthesizing 3 -aminonaphthalimide derivatives bearing carborane clusters $39-42$ by the formation of amide bond between naphthalimide and carborane (Scheme 4).

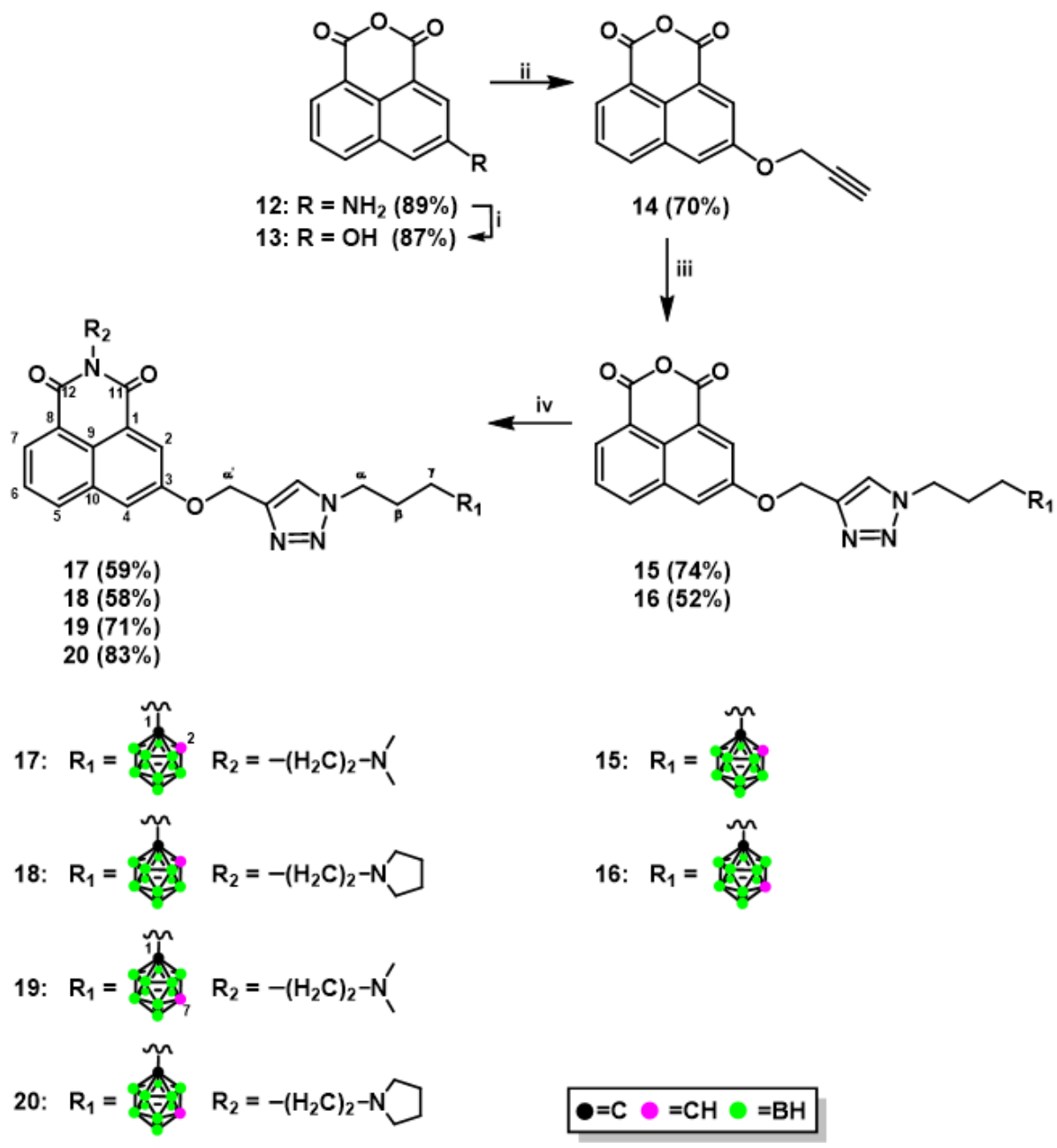

Scheme 2. Synthesis of naphthalimide-ortho-/meta-carborane conjugates 17-20: Reagents and Conditions: (i) $\mathrm{NaNO}_{2}, \mathrm{H}_{2} \mathrm{SO}_{4}, \mathrm{H}_{2} \mathrm{O}, 0^{\circ} \mathrm{C}$, and then $\mathrm{CO}\left(\mathrm{NH}_{2}\right)_{2}, 1 \mathrm{~h}$, $\mathrm{RT}$, and $1 \mathrm{~h}, 10{ }^{\circ} \mathrm{C}$; (ii) $\mathrm{HCCCH}_{2} \mathrm{OH}$, $\mathrm{PPh}_{3}$, THF, $0{ }^{\circ} \mathrm{C}$, and then DIAD, $72 \mathrm{~h}$, RT; (iii) 1-(3-azidopropyl)-1,2-dicarba-closo-dodecaborane (4), $\mathrm{CuSO}_{4} \cdot 5 \mathrm{H}_{2} \mathrm{O}$, sodium ascorbate, $\mathrm{THF} / \mathrm{H}_{2} \mathrm{O}, 3 \mathrm{~h}, 35^{\circ} \mathrm{C}$ (for 15); 1-(3-azidopropyl)-1,7-dicarbacloso-dodecaborane (5), $\mathrm{CuSO}_{4} \cdot 5 \mathrm{H}_{2} \mathrm{O}$, sodium ascorbate, $\mathrm{THF} / \mathrm{H}_{2} \mathrm{O}, 4 \mathrm{~h}, 35^{\circ} \mathrm{C}$ (for 16); (iv) $\mathrm{N}, \mathrm{N}$ dimethylethylenediamine, $\mathrm{EtOH}, 1 \mathrm{~h}, 35^{\circ} \mathrm{C}$, and then $1 \mathrm{~h}, 45{ }^{\circ} \mathrm{C}$ (for 17 and 19); $\mathrm{N}$-(2-aminoethyl)pyrrolidine, $\mathrm{EtOH}, 1 \mathrm{~h}, 35^{\circ} \mathrm{C}$, and then $1-3 \mathrm{~h}, 45^{\circ} \mathrm{C}$ (for 18 and 20). The yields of the compounds are given in parentheses. 


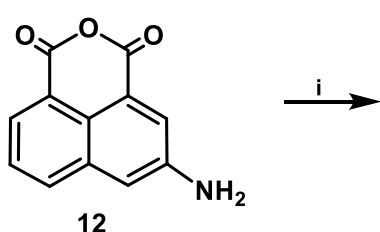<smiles>[R]N1C(=O)c2cccc3cc(N)cc(c23)C1=O</smiles>

$21(90 \%)$

$22(45 \%)$

$\downarrow$ ii

ii<smiles>[R1]CC=Nc1cc2c3c(cccc3c1)C(=O)OC2=O</smiles>

$\mathbf{R}_{\mathbf{2}}$<smiles>[R7]CC=NC1=CC2=CC=CC3=c4c(cc(N=CC[R])cc4=C1)C(=O)N([R2])C23</smiles>

25,26

iii

$27-30$
not isolate

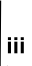

iii

$\mathbf{R}_{2}$
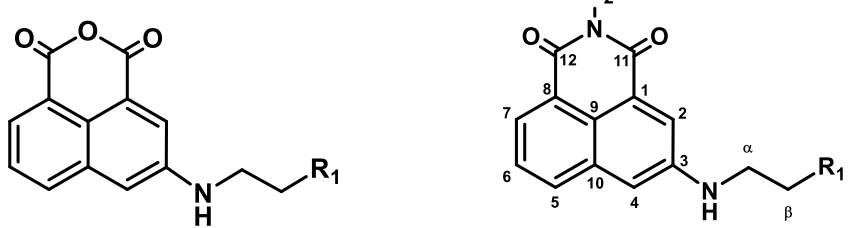

$31(62 \%)$

$33(57 \%)$

$34(47 \%)$

$35(73 \%)$

$36(74 \%)$

21: $\mathrm{R}_{2}=-\left(\mathrm{H}_{2} \mathrm{C}\right)_{2}-\mathrm{N}^{\prime}$

27, 33: $R_{1}=R_{2}^{2}=-\left(\mathrm{H}_{2} \mathrm{C}\right)_{2}-N^{\prime}$

22: $\mathrm{R}_{2}=-\left(\mathrm{H}_{2} \mathrm{C}\right)_{2}-\mathrm{N}$

$25,31: R_{1}=$

28, 34: $R_{1}=$ $R_{2}=-\left(\mathrm{H}_{2} \mathrm{C}\right)_{2}-\mathrm{N}$

26, 32: $R_{1}=$

$\bullet=\mathrm{C} \odot=\mathrm{CH} \odot=\mathrm{BH}$

29, 35: $R_{1}=\overbrace{7}^{11} R_{2}=-\left(H_{2} C\right)_{2}-N^{\prime}$

30, 36: $\mathrm{R}_{1}=2$

Scheme 3. Synthesis of conjugates 31-36 via reductive amination: Reagents and Conditions: (i) $\mathrm{N}, \mathrm{N}$-dimethylethylenediamine, $\mathrm{EtOH}, 1 \mathrm{~h}, 35{ }^{\circ} \mathrm{C}$, and then $1 \mathrm{~h}, 45{ }^{\circ} \mathrm{C}$ (for 21); $\mathrm{N}$-(2-aminoethyl)pyrrolidine, EtOH, $1 \mathrm{~h}, 35^{\circ} \mathrm{C}$, and then $1 \mathrm{~h}, 45^{\circ} \mathrm{C}$ (for 22); (ii) 2-(1,2-dicarba-closo-dodecaboran-1-yl)ethanal (23), THF, $24 \mathrm{~h}$, reflux (for 25, 27, and 28); 2-(1,7-dicarba-closo-dodecaboran-1yl)ethanal (24), THF, $24 \mathrm{~h}$, reflux (for 26); 2-(1,7-dicarba-closo-dodecaboran-1-yl)ethanal (24), $\mathrm{MeOH}$, $24 \mathrm{~h}$, reflux (for 29, 30); (iii) $\mathrm{NaBH}_{3} \mathrm{CN}, 24 \mathrm{~h}$, RT, and then $\mathrm{HCl}, 1 \mathrm{~h}$, RT. The yields of the compounds are given in parentheses. 


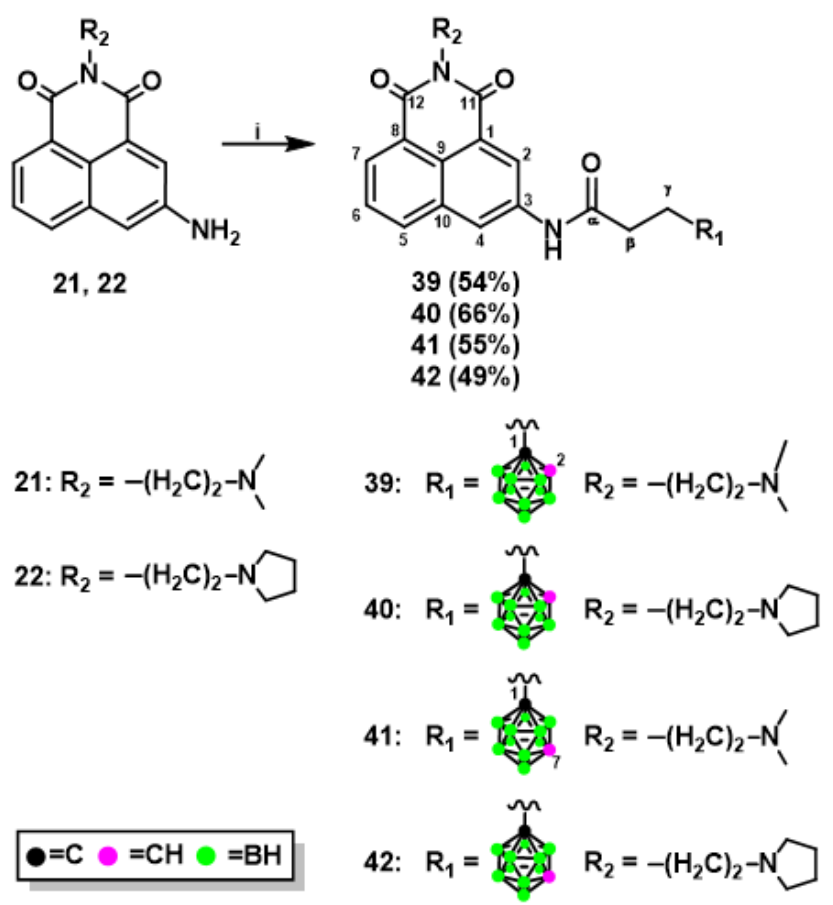

Scheme 4. Modification of naphthalimide derivatives with ortho-/meta-carborane via the formation of amide bonds: Reagents and Conditions: (i) 3-(1,2-dicarba-closo-dodecaboran-1-yl)propionic acid (37) or 3-(1,7-dicarba-closo-dodecaboran-1-yl)propionic acid (38), $\mathrm{PyBOP}, \mathrm{CH}_{2} \mathrm{Cl}_{2}$, TEA, 4-6 h, RT. The yields of the compounds are given in parentheses.

Briefly, 3-amino- $\mathrm{N}$-[2-(dimethylamino)ethyl]-1,8-naphthalimide (21) or 3-amino- $\mathrm{N}$ [2-(N-pyrrolidinyl)ethyl]-1,8-naphthalimide (22) with 3-(1,2-dicarba- closo-dodecaboran1-yl)propionic acid (37) [34] or 3-(1,7-dicarba-closo-dodeca- boran-1-yl)propionic acid (38) [35] was dissolved in anhydrous $\mathrm{CH}_{2} \mathrm{Cl}_{2}$, and then anhydrous benzotriazol-1-yloxytripyrrolidinophosphonium hexafluorophosphate (PyBOP) and (trimethylamine) TEA were added to the solution. After the reaction, the crude products were purified twice by column silica gel chromatography, followed by which conjugates $\mathbf{3 9 - 4 2}$ were obtained as a white solid in moderate or good yield as follows: $54 \%$ (39), 66\% (40), 55\% (41), and $49 \%$ (42). The structure, purity, and homogeneity of these compounds were confirmed by ${ }^{1} \mathrm{H}-$, ${ }^{13} \mathrm{C}-$-, and ${ }^{11} \mathrm{~B}-\mathrm{NMR}, \mathrm{FT}-\mathrm{IR}, \mathrm{MS}$, RP-HPLC (Figures S130-S158 (ESI)), and TLC. An alternative method for synthesizing compounds 39-42 was developed using $N$-succinimidyl active esters containing carborane clusters [36]. However, the products were obtained after 4-10 days at $37{ }^{\circ} \mathrm{C}$ with the maximum yield of $39 \%$. Therefore, this method was not included in the Materials and Methods section in the paper.

\subsubsection{X-ray Structural Analysis}

Each crystal structure contains one molecule of carborane-naphthalimide conjugate in the asymmetric unit. In 39, this unit also contains one molecule of water, while in 41 the unit has two water molecules (Figure 2). The water molecules are well defined in the electron density maps and participate in the hydrogen-bonding networks. In the case of $\mathbf{4 1}$, the two water molecules are involved in linking the $\mathrm{NH}$ group of one molecule with the $\mathrm{N}$ atom of the dimethylamine group from a neighboring molecule, and with the carbonyl oxygen atoms of another neighboring molecule. In the case of compound 39, the single water molecule links the $\mathrm{NH}$ group of one molecule with the dimethylamine group of another molecule, while the carbonyl oxygen takes part in hydrogen bond formation with the $\mathrm{CH}$ group of the carborane cluster of yet another molecule (Figure 3). The donor-acceptor distance of the latter is $3.12 \AA$, which indicates that this is a relatively strong bond for a carbon atom acting as a donor. Our earlier studies have shown that carborane groups can 
participate in weak H-bonding interactions [37], and it was observed that the C-H group of free carboranes is acidic in nature [38]. In both crystal structures, the mitonafide moieties were found to exhibit ring stacking, while the carborane clusters formed their own zones in the crystal lattice.

In compound 41, the aromatic interactions are more extensive and the carborane clusters also interact extensively with one another, whereas in $\mathbf{3 9}$ the division is less clear because the carborane clusters are involved in $\mathrm{H}$-bonding.

A

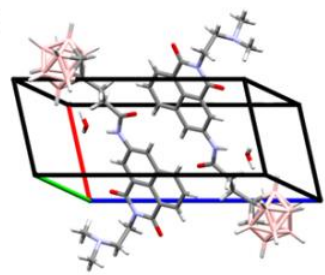

C

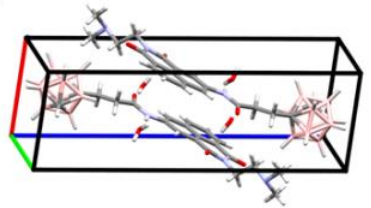

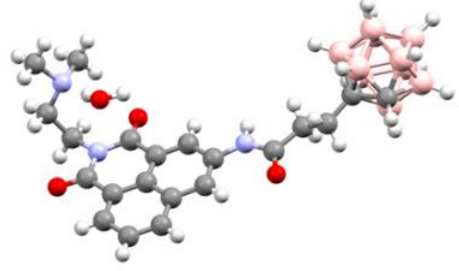

D

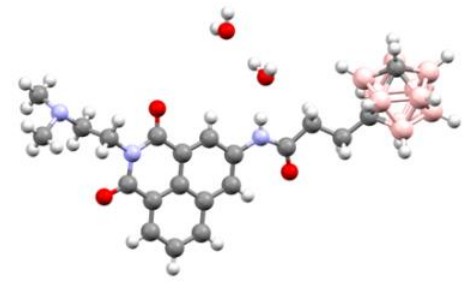

Figure 2. Crystallographic structures of carborane-naphthalimide conjugates: crystal packing and molecular structure observed for 39 (A,B) and 41 (C,D).

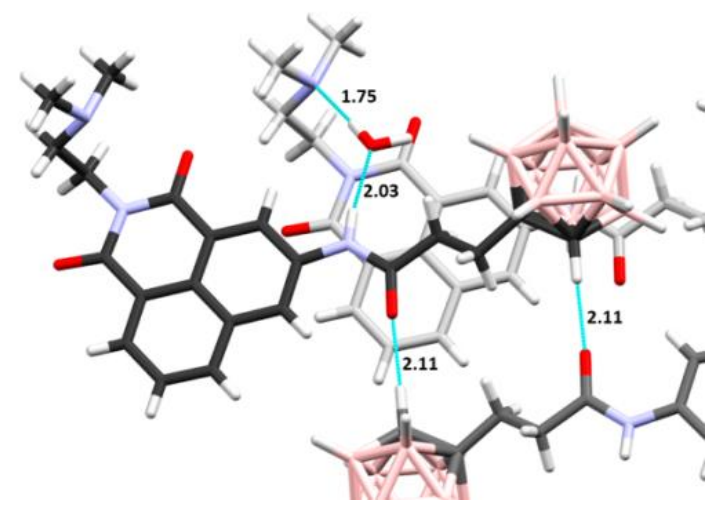

Figure 3. Intermolecular interactions seen in the crystal structure of 39. Hydrogen bonds are indicated by dotted lines, and hydrogen donor-acceptor distances are shown in $\AA$. The three molecules of carborane-naphthalimide conjugate are distinguished by distinct colors of carbon atoms in different shades of gray.

\subsection{Biological Investigation}

\subsubsection{In Vitro Cytotoxic Activity}

The obtained compounds were investigated for in vitro antitumor activity by examining their cytotoxic effects using the MTT tetrazolium dye assay $[39,40]$ against the human cancer cell line HepG2 established from hepatocellular carcinoma. $\mathrm{IC}_{50}$ refers to the drug concentration $(\mu \mathrm{M})$ required to inhibit cell growth by $50 \%$. The $\mathrm{IC}_{50}$ values determined for the synthesized compounds are summarized in Table 1. 
Table 1. Cellular cytotoxic activity of compounds 6-11, 15-20, 31-36, and 39-42.

\begin{tabular}{cc}
\hline Compound & IC $_{\mathbf{5 0}}{ }^{\mathbf{a}}[\boldsymbol{\mu M}]$ \\
\hline $\mathbf{6}$ & $115.38 \pm 1.84$ \\
$\mathbf{7}$ & $103.78 \pm 1.16$ \\
$\mathbf{8}$ & $4.33 \pm 0.82$ \\
$\mathbf{9}$ & $3.10 \pm 0.42$ \\
$\mathbf{1 0}$ & $8.02 \pm 0.46$ \\
$\mathbf{1 1}$ & $4.79 \pm 1.36$ \\
$\mathbf{1 5}$ & $67.78 \pm 2.32$ \\
$\mathbf{1 6}$ & $61.47 \pm 2.33$ \\
$\mathbf{1 7}$ & $9.68 \pm 2.00$ \\
$\mathbf{1 8}$ & $14.85 \pm 0.86$ \\
$\mathbf{1 9}$ & $14.30 \pm 2.88$ \\
$\mathbf{2 0}$ & $11.89 \pm 0.48$ \\
$\mathbf{3 1}$ & $53.09 \pm 3.68$ \\
$\mathbf{3 2}$ & $40.81 \pm 1.67$ \\
$\mathbf{3 3}$ & $4.77 \pm 1.89$ \\
$\mathbf{3 4}$ & $8.44 \pm 1.70$ \\
$\mathbf{3 5}$ & $8.65 \pm 0.10$ \\
$\mathbf{3 6}$ & $5.63 \pm 0.16$ \\
$\mathbf{3 9}$ & $10.63 \pm 2.69$ \\
$\mathbf{4 0}$ & $12.59 \pm 0.68$ \\
$\mathbf{4 1}$ & $10.38 \pm 0.57$ \\
$\mathbf{4 2}$ & $6.17 \pm 1.21$ \\
\hline
\end{tabular}

$\bar{a}$ Compound concentration required to; inhibit tumor cell growth by $50 \%$; Mitonafide $\mathrm{IC}_{50}<1$ [20]; Pinafide $\mathrm{IC}_{50}=1.23 \pm 0.15[20]$.

Generally, naphthalimides modified with carboranes (8-11, 17-20, 33-36, 39-42) exhibited more cytotoxicity than naphthalic anhydrides containing carborane clusters $(6,7$, 15, 16, 31, and 32). A comparison analysis of the naphthalimides in the series in terms of their activity revealed that conjugates 8-11 synthesized via click reaction (triazole ring attached directly to the heteroaromatic system) were the most cytotoxic than the modified naphthalimides that were obtained using click reaction (17-20, triazole ring attached through an oxygen atom to the heteroaromatic system), reductive amination (33-36), or amidation (39-42). The pinafide analog containing ortho-carborane 9 was identified to be the most cytotoxic to the tested tumor cell line at a concentration as low as $3.10 \mu \mathrm{M}$. The pinafide analog 11 containing meta-carborane was slightly less cytotoxic with an $\mathrm{IC}_{50}$ value of $4.79 \mu \mathrm{M}$. The mitonafide analog modified with ortho-carborane $8\left(\mathrm{IC}_{50}=4.33 \mu \mathrm{M}\right)$ showed a moderately lower cytotoxic activity compared to compound $\mathbf{9}$, but the highest activity among the mitonafide analogs modified with a carborane cluster $(\mathbf{1 0}, \mathbf{1 7}, \mathbf{1 9}, \mathbf{3 5}, \mathbf{3 9}$, 41). It is worth mentioning that compounds 8 and 9 modified with ortho-carborane and compound $\mathbf{1 1}$ modified with meta-carborane were more active than naphthalimides bearing ortho- or meta-carborane at the $\mathrm{N}$-imide position (5.95 and $7.84 \mu \mathrm{M}$, respectively) [20].

Due to the presence of an additional oxygen atom in their structure, in comparison to conjugates 8-11, modified naphthalimides 17-20 have showed significantly lower cytotoxic activity with an $\mathrm{IC}_{50}$ of $9.68-14.85 \mu \mathrm{M}$, with the highest value determined for mitonafide analog 17 bearing an ortho-carborane.

Naphthalimide-carborane conjugates 33-36 containing an alkane linker between the amine group at position 3 of the ring and the carborane cluster showed higher cytotoxic activity than conjugates 17-20, but slightly lower activity compared to 8-11. Mitonafide analog bearing ortho-carborane 33 was the most active among the synthesized compounds, with an $\mathrm{IC}_{50}$ value of $4.77 \mu \mathrm{M}$. Compounds $39-42$ synthesized by amide bond formation displayed lower cytotoxic activity than 33-36, because of the presence of a $\mathrm{C}=\mathrm{O}$ group between the amine group and the carborane cluster. Their cytotoxic activity was around one to two times lower $\left(\mathrm{IC}_{50}=6.77-12.59 \mu \mathrm{M}\right)$ than compounds 33-36 $\left(\mathrm{IC}_{50}=4.77-8.65 \mu \mathrm{M}\right)$. Naphthalic anhydrides 15, 16, 31, and 32 showed moderate cytotoxicity against HepG2 cells $\left(\mathrm{IC}_{50}=40.81-67.78 \mu \mathrm{M}\right)$, while 6 and 7 were not toxic $\left(\mathrm{IC}_{50}>100 \mu \mathrm{M}\right)$. 


\subsubsection{Cell Cycle Analysis by Flow Cytometry}

Cell cycle disorders such as phase arrest might be an important cause of inhibition of cancer cell growth and consequently the loss of cell viability [41]. Previous research showed that many drugs induced cell cycle arrest at the G2/M phase in cancer cells [42]. To reveal the mechanism behind the inhibitory effect of the synthesized compounds on cellular viability, we sought to examine the cell cycle regulation. For this purpose, HepG2 cells were exposed to compounds $6(115 \mu \mathrm{M}), 7(104 \mu \mathrm{M}), \mathbf{8}(4 \mu \mathrm{M}), \mathbf{9}(3 \mu \mathrm{M}), \mathbf{1 0}(8 \mu \mathrm{M})$, $11(5 \mu \mathrm{M}), \mathbf{1 5}(68 \mu \mathrm{M}), \mathbf{1 6}(61 \mu \mathrm{M}), \mathbf{1 7}(10 \mu \mathrm{M}), \mathbf{1 8}(15 \mu \mathrm{M}), \mathbf{1 9}(14 \mu \mathrm{M}), \mathbf{2 0}(12 \mu \mathrm{M}), \mathbf{3 1}(53 \mu \mathrm{M})$, $32(42 \mu \mathrm{M}), 33(5 \mu \mathrm{M}), 34(8 \mu \mathrm{M}), 35(9 \mu \mathrm{M}), 36(6 \mu \mathrm{M}), 39(11 \mu \mathrm{M}), 40(13 \mu \mathrm{M}), \mathbf{3 1}(10 \mu \mathrm{M})$, and $42(6 \mu \mathrm{M})$. The chosen concentration of each of these compounds corresponded to the whole $\mathrm{IC}_{50}$ value. Mitonafide and pinafide were used as reference compounds in this analysis. After exposure, HepG2 cells were examined by flow cytometry, and their DNA content was measured by PI staining. Based on the DNA content, it was found that compounds 6, 9, 10, 16-20, 33, 34, 40, and 41 exerted different effects on cell cycle than mitonafide and pinafide (Figure 4 and Figure S159 (ESI)) which induced cell cycle arrest at the $S$ and G2M phases [20], respectively.

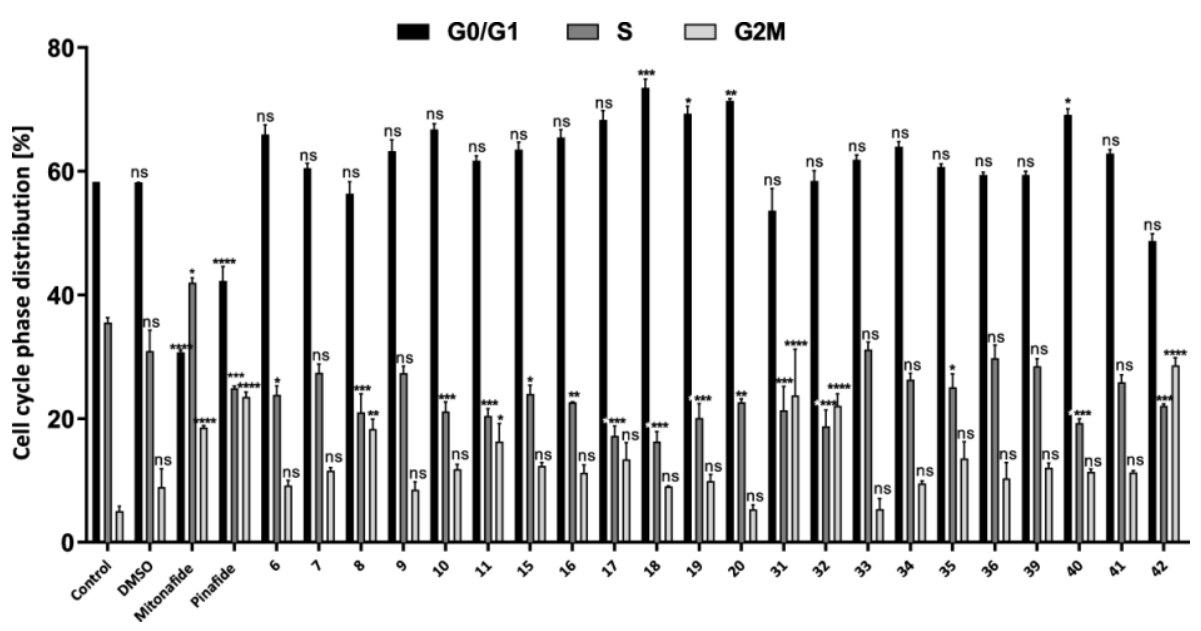

Figure 4. Effect of compounds $6(115 \mu \mathrm{M}), 7(104 \mu \mathrm{M}), 8(4 \mu \mathrm{M}), \mathbf{9}(3 \mu \mathrm{M}), \mathbf{1 0}(8 \mu \mathrm{M}), \mathbf{1 1}(5 \mu \mathrm{M})$, $15(68 \mu \mathrm{M}), 16(61 \mu \mathrm{M}), 17(10 \mu \mathrm{M}), 18(15 \mu \mathrm{M}), 19(14 \mu \mathrm{M}), 20(12 \mu \mathrm{M}), 31,(53 \mu \mathrm{M}), 32(42 \mu \mathrm{M})$, $33(5 \mu \mathrm{M}), 34(8 \mu \mathrm{M}), 35(9 \mu \mathrm{M}), 36(6 \mu \mathrm{M}), 39(11 \mu \mathrm{M}), 40(13 \mu \mathrm{M}), 41(10 \mu \mathrm{M})$, and $42(6 \mu \mathrm{M})$ on cell cycle distribution in HepG2 cells. The cells were treated with these compounds at a concentration corresponding to the previously estimated $\mathrm{IC}_{50}$ value. The graph presents the percentage of cells in the G0/G1, S, and G2M phases, respectively. Data are presented as mean \pm SD of three independent experiments. Statistical significance is indicated by asterisks: (ns) $p>0.05,\left({ }^{*}\right) p<0.05,\left({ }^{* *}\right) p<0.01$, $\left.{ }^{* * *}\right) p<0.001$, and $\left.{ }^{* * * *}\right) p<0.0001$.

The tested compounds affected the cell cycle by increasing the percentage of the cells in G0/G1 by up to $73.5 \%$ (compound 18 ) compared to the control (58.3\%). Accumulation of cells in this phase delayed the progression of the cell cycle and the beginning of the $S$ phase. Previous studies showed that naphthalimide derivatives that were modified with a carborane or metallacarborane cluster at the $\mathrm{N}$-imide position also caused cell cycle arrest at the G0/G1 phase [20]. In this study, we found that conjugates $7, \mathbf{8}, \mathbf{1 1}, \mathbf{1 5}, \mathbf{3 1}, \mathbf{3 2}, \mathbf{3 5}$, 36,39 , and 42 arrested the cell cycle in G2M, similar to pinafide, of which compound 42 increased the number of cells in this phase by up to $28.1 \%$.

\subsubsection{Oxidative Stress Measurement in HepG2 Cells by Flow Cytometry}

To shed light on the mechanism responsible for the inhibitory effect of the compounds on cellular viability, we examined their ability to induce the production of ROS. ROS production has been proposed as one of the mechanisms by whicH-Naphthalimides and their 
derivatives induced cell cycle arrest and apoptosis on cancer cells, which was confirmed by the flow cytometry analysis of oxidative stress induction [2].

To confirm whether ROS were involved in the induction of cell cycle arrest by compound, the level of intracellular ROS was analyzed. HepG2 cells were cultured for $24 \mathrm{~h}$ with compounds $6(57.5 \mu \mathrm{M}), 7(52 \mu \mathrm{M}), 8(2 \mu \mathrm{M}), \mathbf{9}(1.5 \mu \mathrm{M}), \mathbf{1 0}(4 \mu \mathrm{M}), \mathbf{1 1}(2.5 \mu \mathrm{M})$, $15(34 \mu \mathrm{M}), 16(30.7 \mu \mathrm{M}), \mathbf{1 7}(4.9 \mu \mathrm{M}), \mathbf{1 8}(7.5 \mu \mathrm{M}), 19(7.2 \mu \mathrm{M}), 20(6 \mu \mathrm{M}), \mathbf{2}(20.4 \mu \mathrm{M})$, $39(5.3 \mu \mathrm{M}), 40(6.3 \mu \mathrm{M}), \mathbf{4 1}(5.2 \mu \mathrm{M})$, and $42(3 \mu \mathrm{M})$ (Figure 5 and Figure S160 (ESI)). The selected concentration of each compound corresponded to half of its $\mathrm{IC}_{50}$ value. Mitonafide and pinafide were used as reference compounds in the analysis.

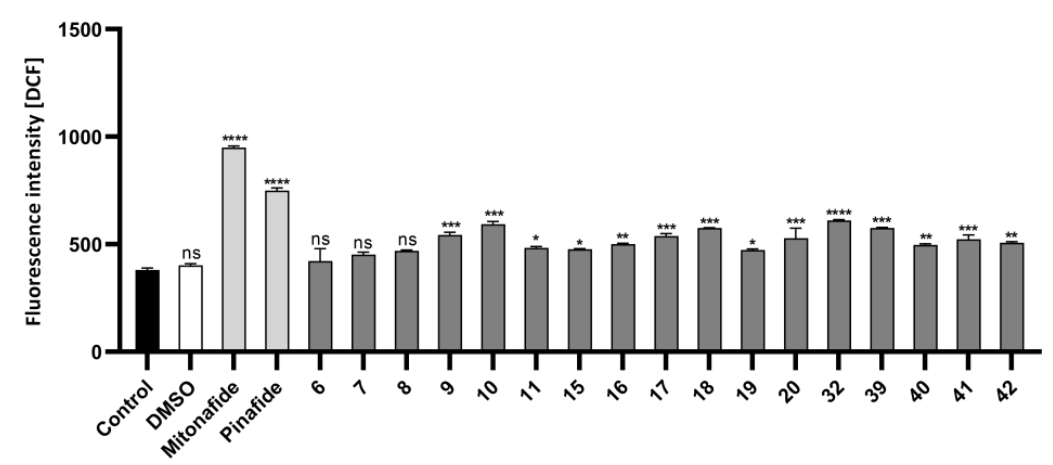

Figure 5. ROS production in HepG2 cells after $24 \mathrm{~h}$ of incubation with compounds $6(57.5 \mu \mathrm{M})$, $7(52 \mu \mathrm{M}), 8(2 \mu \mathrm{M}), \mathbf{9}(1.5 \mu \mathrm{M}), \mathbf{1 0}(4 \mu \mathrm{M}), 11(2.5 \mu \mathrm{M}), 15(34 \mu \mathrm{M}), 16(30.7 \mu \mathrm{M}), 17(4.9 \mu \mathrm{M})$, $18(7.5 \mu \mathrm{M}), \mathbf{1 9}(7.2 \mu \mathrm{M}), 20(6 \mu \mathrm{M}), \mathbf{3 2}(20.4 \mu \mathrm{M}), \mathbf{3 9}(5.3 \mu \mathrm{M}), \mathbf{4 0}(6.3 \mu \mathrm{M}), \mathbf{4 1}(5.2 \mu \mathrm{M})$, and $42(3 \mu \mathrm{M})$. The concentration chosen for each compound corresponded to half of its $\mathrm{IC}_{50}$ value. Intracellular ROS production was measured by dual staining with $\mathrm{H}_{2}$ DCFDA/PI. The intensity of DCF fluorescence corresponded to the intracellular level of ROS in HepG2 cells. Mean fluorescence intensity was measured by flow cytometry. Data are presented as mean \pm SD of three independent experiments. Statistical significance is indicated by asterisks: (ns) $\left.\left.p>0.05,\left(^{*}\right) p<0.05,{ }^{* *}\right) p<0.01,{ }^{* * *}\right) p<0.001$, and $\left.{ }^{* * * *}\right) p<0.0001$.

The intracellular level of ROS was analyzed by dual staining with $\mathrm{H}_{2}$ DCFDA/PI. DCF green fluorescence was triggered in the presence of ROS proportional to the intensity of oxidative stress. The most potent ROS inducer, among conjugates 6-11, 15-20, 32, 39-42, was mitonafide. Conjugates 10, 18, 32, and 39 were less effective. Furthermore, compounds $9, \mathbf{1 7}, \mathbf{2 0}$, and $\mathbf{4 0 - 4 2}$ were more promising compared to control.

\subsubsection{Analysis of 8-oxo-dG in HepG2 Cells}

As compounds 31 and 33-36 exhibited autofluorescence (Figure S161 (ESI)), the level of intracellular ROS was measured by determining the content of 2'-deoxy-8-oxoguanosine (8-oxo-dG) in the enzymatic DNA hydrolysates obtained from HepG2 cells treated with the tested compounds. $2^{\prime}$-Deoxyguanosine is known to be the most susceptible to oxidation among the four canonical nucleosides, and 8-oxo-dG is the major oxidation product in DNA [43]. Under normal conditions, a genome has one 8-oxo-dG molecule per $10^{5}-10^{6}$ guanosines, corresponding to thousands of 8-oxo-dG molecules per single cell. In this study, the content of 8-oxo-dG was measured using HPLC-UV-ED. The number of 8-oxo$\mathrm{dG}$ molecules per $10^{6} \mathrm{dG}$ was calculated (Table 2). We found that all tested compounds significantly elevated the number of 8-oxo-dG molecules compared to untreated control. Moreover, treatment with compound 35 caused much higher oxidative disturbances in DNA than mitonafide [20] resulting in almost four times higher number of 8-oxo-dG molecules in the cells (107.34 \pm 0.57 vs. 28.24 per $10^{6} \mathrm{dG}$, respectively). 
Table 2. 8-Oxo-dG level in cellular DNA after treatment with compounds 31 and 33-36.

\begin{tabular}{cc}
\hline Compound & 8-oxo-dG/10 $\mathbf{6} \mathbf{d G} \pm \mathbf{S D}$ \\
\hline Control & $8.77 \pm 0.02$ \\
$\mathbf{3 1}$ & $31.77 \pm 0.09$ \\
$\mathbf{3 3}$ & $24.43 \pm 0.02$ \\
$\mathbf{3 4}$ & $29.43 \pm 0.11$ \\
$\mathbf{3 5}$ & $107.34 \pm 0.57$ \\
$\mathbf{3 6}$ & $25.33 \pm 0.13$ \\
\hline
\end{tabular}

Mitonafide $28.24 \pm 0.18$ [20].

\subsubsection{Apoptosis/Necrosis, Autophagy, and Ferroptosis Assays by Flow Cytometry}

Apoptosis and necrosis are the two major processes leading to cell death. Of these, the former is characterized by specific morphological and biochemical features including chromatin condensation, cell shrinkage, activation of caspase, and the loss of mitochondrial membrane potential [44]. It was found, that naphthalimide derivatives could induce cell death through apoptosis in the tested HepG2 and Bel-7402 cells [45].

To investigate whether the tested compounds induced apoptosis in HepG2 cells, we incubated the cells witH-Naphthalimide-carborane cluster conjugates for $24 \mathrm{~h}$ and performed a flow cytometry analysis. The compounds that did not show autofluorescence were analyzed by dual staining using YO-PRO-1/PI, while those showing strong green autofluorescence $(31,33-36)$ were analyzed using Alexa Fluor 647 annexin V conjugate staining. The concentration chosen for each compound corresponded to the whole $\mathrm{IC}_{50}$ values. Mitonafide and pinafide were tested as reference compounds in this analysis.

The results indicated that the conjugates $6,7,17,19,20$, and 39-42 mainly promoted the apoptosis mode of cell death (Figure 6A and Figure S162 (ESI); Table S1 (ESI)). Compounds $17,19,39$, and 40 induced early apoptosis (expressed as a percentage of apoptotic cells), and only a few late apoptotic cells were seen. Incubation with compounds 20 and $\mathbf{4 1}$ induced mainly the early stages of apoptosis with a moderate level of late apoptosis $(13.35 \%$ and $18.60 \%$, respectively). Compounds 6,7 , and 42 more rapidly induced cell death, where numerous cells underwent late apoptosis $(42)$ and necrosis $(6,7)$.

Among the tested compounds, $\mathbf{3 1}$ and 33-36 were found to be apoptosis inducers. Compounds 33, 35, and 36 displayed strong apoptotic properties, but compound $\mathbf{3 5}$ was identified as the strongest proapoptotic promoter and induced apoptosis in nearly $70 \%$ of the treated cells after $24 \mathrm{~h}$ (Figure 6B and Figure S163 (ESI)). This compound was also found to be a very potent inducer of oxidative stress (Table 2).

Interestingly, some of the modified naphthalimides (8-11 and 18) did not exhibit positive green fluorescence signal corresponding to apoptotic cells, although their applied concentration corresponded to the whole $\mathrm{IC}_{50}$ value. To investigate whether these conjugates induced another type of regulated cell death (autophagy) in the tested HepG2 cells, we performed flow cytometry analysis using Green Detection Reagent that selectively stained autophagic vacuoles. For a strong activation of positive signal of autophagy, HepG2 cells were incubated with rapamycin, a potent inhibitor of mTOR [46]. Autophagy plays an important role in cellular homeostasis and disease pathogenesis and is also one of the reasons for the inhibition of cell growth. Through this process, cytosolic components and organelles are delivered to lysosomes for degradation. Small chemical molecules that have the ability to modulate autophagy may have pharmacological value for the treatment of various diseases [47].

It has been reported that the analog NPC-16 (naphthalimide-polyamine conjugate) triggered both apoptosis and autophagy in HepG2 cells, and further autophagy facilitated cellular apoptosis. Furthermore, mTOR signal pathway was involved in NPC-16-mediated autophagy in HepG2 cells [45]. In this study, compounds 8-11 and $\mathbf{1 8}$ were detected as potent activators of autophagy (Figure 6C and Figure S164 (ESI)). These conjugates increased fluorescence by $26-37 \%$ compared to the control, with the highest increase of fluorescence caused by conjugate 11, while rapamycin increased fluorescence by $24 \%$. 
Autophagy typically precedes or occurs along with apoptosis. We found that the conjugates tested as mediators in this study could promote or inhibit cell apoptosis in HepG2 cells at their higher concentration or with extended incubation time.
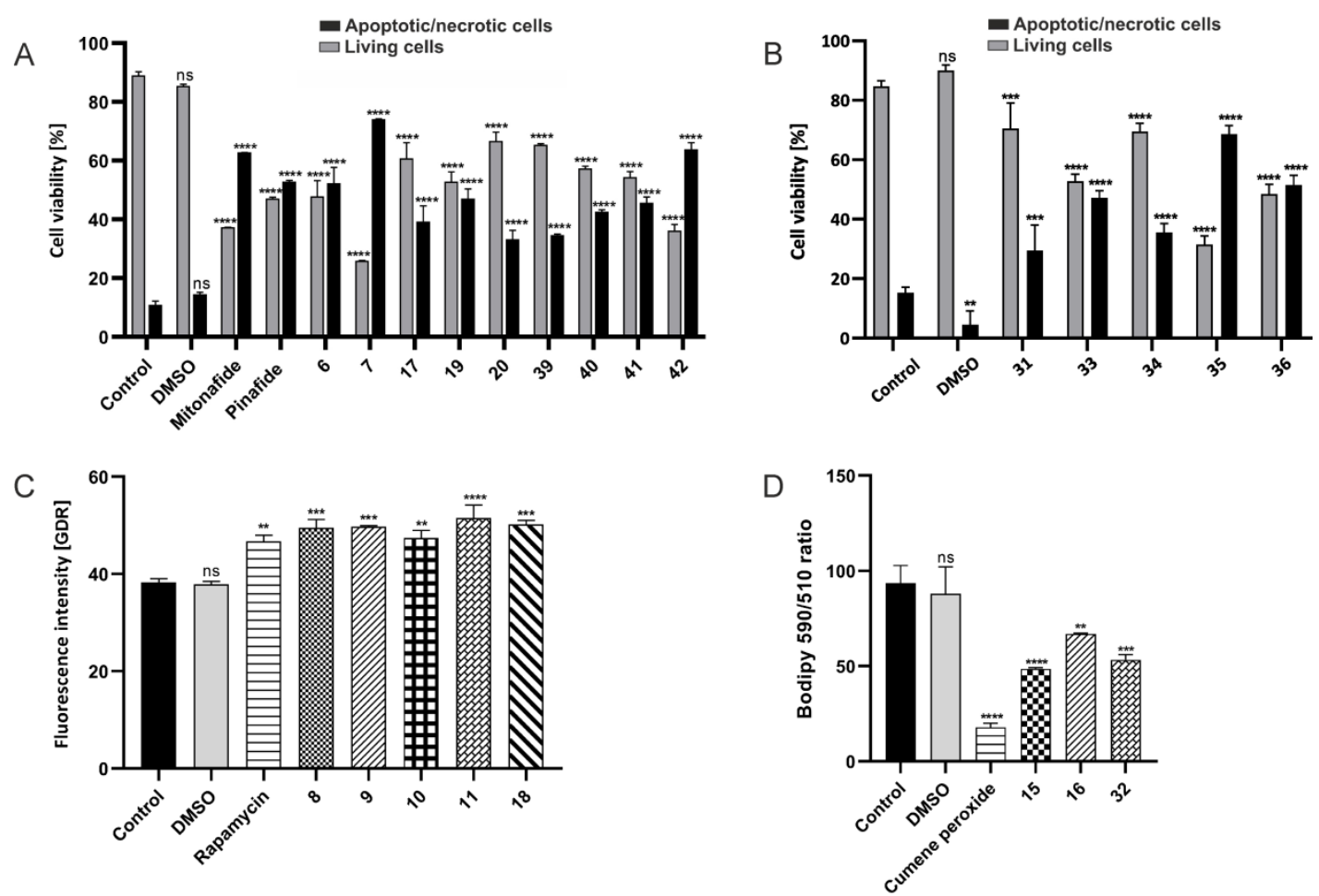

Figure 6. Effect of compound $6(115 \mu \mathrm{M}), 7(104 \mu \mathrm{M}), \mathbf{8}(4 \mu \mathrm{M}), \mathbf{9}(3 \mu \mathrm{M}), \mathbf{1 0}(8 \mu \mathrm{M}), \mathbf{1 1}(5 \mu \mathrm{M}), 15(68 \mu \mathrm{M}), \mathbf{1 6}(61 \mu \mathrm{M})$, $17(10 \mu \mathrm{M}), 18(15 \mu \mathrm{M}), 19(14 \mu \mathrm{M}), 20(12 \mu \mathrm{M}), 31(53 \mu \mathrm{M}) 32(42 \mu \mathrm{M}), 33(5 \mu \mathrm{M}), 34(8.5 \mu \mathrm{M}), 35(9 \mu \mathrm{M}), 36(6 \mu \mathrm{M})$, $39(11 \mu \mathrm{M}), 40(13 \mu \mathrm{M}), 41(10 \mu \mathrm{M})$, and $42(6 \mu \mathrm{M})$ on cell death in HepG2 cells. The cells were treated with these compounds at a concentration corresponding to the whole $\mathrm{IC}_{50}$ value. Quantitative flow cytometry analysis was performed to evaluate apoptosis (A,B), autophagy (C), and ferroptosis (D) induced by compounds after $24 \mathrm{~h}$ of treatment. Data are presented as mean \pm SD of three independent experiments. Statistical significance is indicated by asterisks: (ns) $p>0.05,\left({ }^{* *}\right) p<0.01$, $\left.{ }^{* * *}\right) p<0.001$, and $\left(^{* * * *}\right) p<0.0001$.

Unexpectedly, we observed that modified naphthalimides 15, 16, and 32 generated stronger than expected fluorescent signals during the apoptosis/necrosis analysis at a concentration corresponding to their whole $\mathrm{IC}_{50}$ value. Compound 32 was detected as a potent ROS inducer (Figure 5). Intense oxidative stress is a feature of ferroptosis, which is a relatively recently discovered type of programmed cell death and is usually accompanied by high iron accumulation and lipid peroxidation. Recent studies have shown that ferroptosis is closely related to the pathophysiological processes of many diseases and plays an important regulatory role in the development and progression of, for example, tumors, neurological disorders, acute kidney injury, and ischemia/reperfusion [48]. Therefore, we analyzed conjugates 15, 16, and 32 for their ability to induce ferroptosis. Cumene peroxide was used as a potent inducer of lipid peroxidation (positive control). The rate of lipid peroxidation was estimated using the reagent $581 / 591 \mathrm{C} 11$ that localizes in the membranes of live cells. On the basis of red and green fluorescence data obtained by flow cytometry, we estimated the 590/510 ratio which is inversely proportional to the amount of peroxided lipids. The tested modified naphthalimides caused lipid peroxidation (Figure 6D and Figure S165 (ESI)), although the highest peroxidation rate, indicated by the lowest 590/510 ratio, was found in the cells that were treated with conjugate 15. 


\subsubsection{Fluorescence Imaging of Lysosomes}

Lysosomes, which are one of the vital organelles, participate in many physiological processes such as cell apoptosis, cell cycle progression, and supply of cellular energy. Recent research suggests that lysosomal dysfunction is a characteristic of autoimmune disorders and neurodegenerative diseases including lupus, rheumatoid arthritis, multiple sclerosis, and Alzheimer's and Parkinson's disease [49]. Due to the acidic feature of lysosomes, a series of lysosome-targeting probes of naphthalimide derivatives, in which the morpholine group is modified, have been designed and synthesized to enhance their targeting effects to the lysosomes through electronic interactions [50]. Lysosome-targeting anticancer agents based on naphthalimide derivatives are limited [51]. It was shown that $N, N$-bis(3aminopropyl)methylamine-bridged bis-naphthalimide derivatives exhibited fluorescence imaging in lysosomes in HeLa cells [52]. Due to fluorescence selection of naphthalimidecarborane conjugates (Figure S161 (ESI)), we studied the lysosome-targeting behavior and imaging capacity of compounds 33,34 , and 36 by performing co-localization experiments using a commercial lysosomal tracker (DND-99) as the co-localization agent. We observed that the fluorescence of compounds 33, 34, and 36 (green panels) in the co-stained cells overlapped well with that of DND-99 (red panels), as supported by their merged images (right panels) shown in Figure 7. This suggests that compounds 33, 34, and 36 can specifically target the lysosomes of living cells with good cell membrane permeability.

\subsubsection{Human Topoisomerase II $\alpha$ Relaxation Assay}

The substituted 1,8-naphthalimides can act as DNA intercalators stabilizing DNAtopoisomerase II complexes. Their interaction with DNA disrupts the cleavage-relegation equilibrium of Topo II, thus resulting in the formation of broken DNA strands [51,53].

Carborane cluster-modified naphthalic anhydrides $(6,7,15,16,31,32)$ and naphthalimides (8-11, 17-20, 33-36, 39-42) were tested in the screening assay for human topoisomerase II $\alpha$ inhibitory activity, at a concentration of $100 \mu \mathrm{M}$ (Figure S166 (ESI)). The inhibitory activity, manifested as the presence of the supercoiled DNA fraction of pBR322 plasmid, was observed for compound 7 , and to some extent, for compound 6 (as the presence of a separate band of supercoiled plasmid as well as a discrete smear below the relaxed DNA fraction). Therefore, we subjected both compounds to further detailed analyses of inhibitory potential within the concentration range of $25-200 \mu \mathrm{M}$. As expected, compound 6 demonstrated relatively weak inhibitory effect on human topoisomerase II $\alpha$, with a maximum inhibitory activity of $19.8 \%$ at $100 \mu \mathrm{M}$ (at $200 \mu \mathrm{M}$ the inhibitory activity of the compound was slightly lower (14.5\%) probably due to precipitation) (Figure 8A). Compound 7 acted in a concentration-dependent manner, and the best inhibitory activity was detected at 100 and $200 \mu \mathrm{M}$ (19\% and 44\% inhibition, respectively) (Figure 8B). Noteworthy was the presence of a relatively significant amount of DNA in the gel wells, which increased in proportion with the concentration of compound 7. One can assume that this fraction could have been generated either by additional inhibition of the enzyme's decatenation activity or by the intercalation of the compound into a DNA helix leading to the formation of a covalent complex between the DNA and the enzyme, which cannot migrate in the agarose gel (no protein denaturant was added to the reaction) [54]. At the same time, a trapped topoisomerase could not relax supercoiled plasmids and hence the decrease in enzyme's activity and the appearance of the supercoiled DNA band. The concentration-dependent inhibitory activity of compound 7 suggests that the used concentration might not be sufficient for the compound to intercalate into all plasmid molecules or that the binding of compound to the DNA might be reversible, resulting in an incomplete inhibition of the enzyme activity and the appearance of a relaxed DNA fraction. Considering that enzyme inhibition can be determined as a sum of the amount of supercoiled DNA and the DNA fraction trapped in the gel wells, we calculated $30 \%$ and $72 \%$ inhibition of topoisomerase activity for compound 7 at the concentration of 100 and $200 \mu \mathrm{M}$, respectively, and an $\mathrm{IC}_{50}$ value (concentration that inhibits the activity of an enzyme by 50\%) of $134 \mu \mathrm{M}$. 


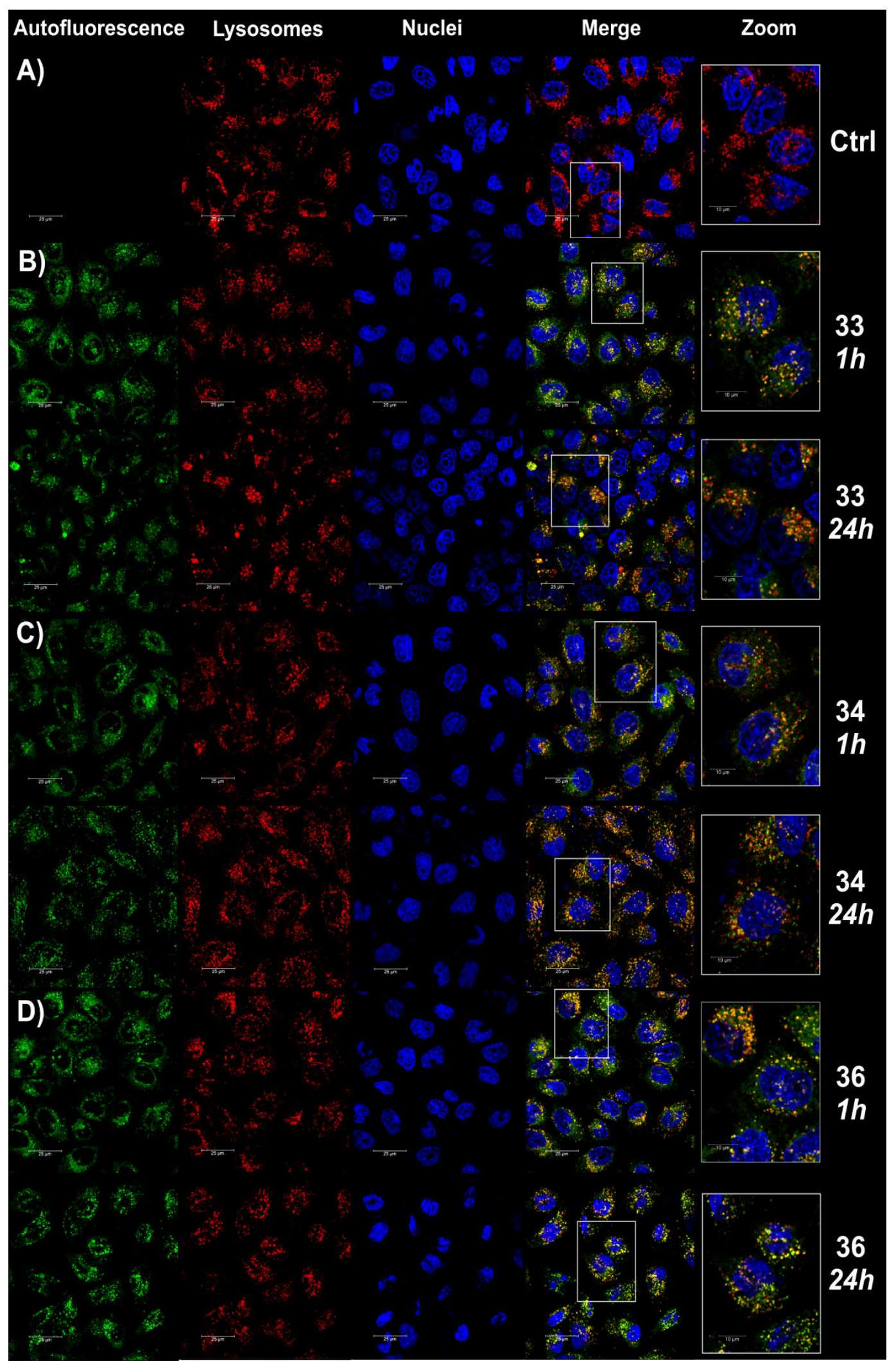

Figure 7. Confocal microscopy analysis of the co-localization of compounds 33, 34, and 36. The analysis was carried out after 1 and $24 \mathrm{~h}$ of treatment of the cells with compounds 33 (B), 34 (C) and 36 (D) at the final concentration corresponding to the whole $\mathrm{IC}_{50}$ values. Untreated cells were used as a control (A). Panels with green fluorescence show the autofluorescence of the investigated compounds (Ex/Em 488/500-600 nm), panels with red fluorescence show the autofluorescence of stained lysosomes (Ex/Em 561/585-655 nm), and panels with blue fluorescence present nuclei labeling (Ex/Em 405/430-480 nm). Merged images are shown in the right panels. 

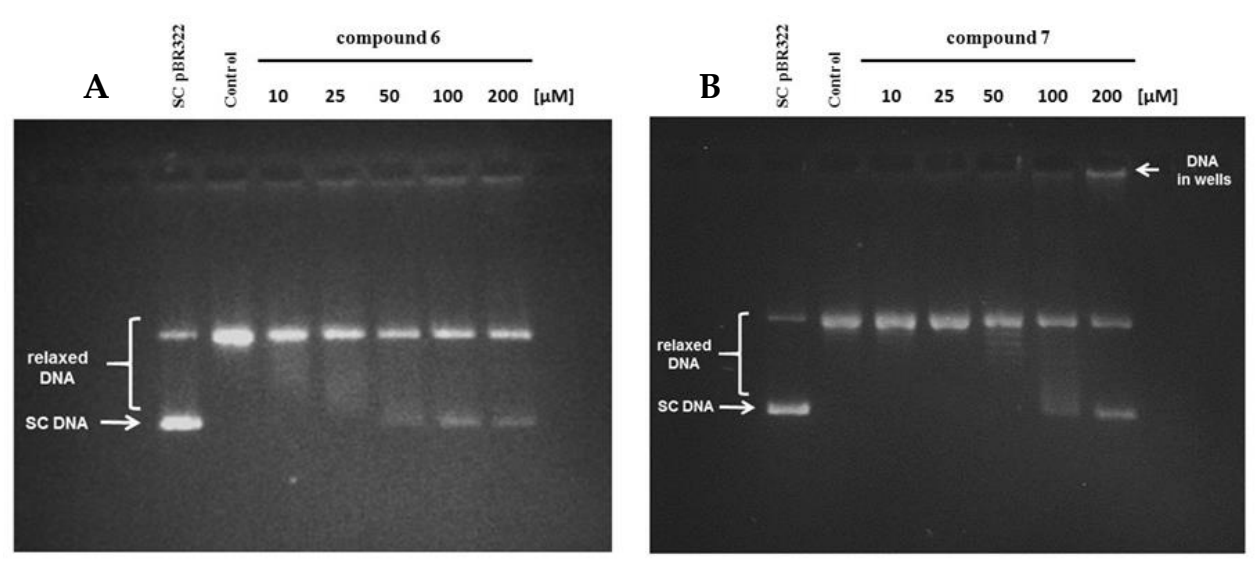

Figure 8. Inhibition of the relaxation activity of human topoisomerase II $\alpha$ in the presence of compounds 6 (A) and 7 (B) at concentrations of 10, 25, 50, 100, and $200 \mu \mathrm{M}$. SC—supercoiled DNA.

\subsection{Physicochemical Investigation with DNA}

DNA melting is the process of separating the double-helical DNA into two single strands by disrupting the stable hydrogen bonding and base stacking interactions [55]. The melting temperature $\left(T_{\mathrm{m}}\right)$ of DNA is defined as the point at which half of the DNA strands are in the double-helical state and the other half in a random-coil state [56]. DNA helix melting is performed by measuring the absorbance of DNA at $260 \mathrm{~nm}$ as a function of temperature. A large increase in $T_{\mathrm{m}}\left(3-8{ }^{\circ} \mathrm{C}\right)$ is observed only for the strong intercalation type of interaction, whereas groove-binding interaction of small molecules with DNA leads to insignificant amendment of $T_{\mathrm{m}}$. In our study, we conducted an experiment to monitor the changes in $T_{\mathrm{m}}$ for ct-DNA in the absence and presence of modified naphthalimides to understand the interaction between these compounds and ct-DNA (Table 3, Figures S167-S171 (ESI)).

Thermal melting experiments showed that the studied compounds 9-11, 15-20, 32-36, 41 , and 42 caused negligible stabilization of ct-DNA, while conjugates $6,8,39$, and 40 caused better DNA stabilization. In comparison to mitonafide and pinafide (Table 3, Figure S171 (ESI)), the conjugates rather excluded classical intercalation as a dominant binding mode, which indicates a different mode of interaction with DNA.

Some of the modified anhydrides, 7 and 31, caused destabilization of ct-DNA. Druginduced destabilization of DNA helix represents a novel antitumor mechanism of action and is associated with particular intercalation processes or postalkylation distortion of DNA. DNA-destabilizing compounds are relatively rare and constitute a minor proportion of DNA-interacting molecules (which primarily stabilize the double helix). Certain monoor bis-intercalators and DNA alkylating agents exhibit such DNA-destabilizing effects. The formation of locally destabilized DNA portions could interfere with protein/DNA recognition and thus potentially affect several crucial cellular processes, such as DNA repair, replication, and transcription [57].

To better understand the interactions of DNA and modified naphthalimides, we conducted circular dichroism (CD) measurements. $C D$ is a powerful and reliable technique to investigate the conformational changes in DNA morphology during interactions between a small molecule and DNA. The CD spectra of the B-form DNA duplex generally display a positive Cotton effect at $270 \mathrm{~nm}$ and a negative effect at approximately $250 \mathrm{~nm}$, witH-Nearly equal magnitudes of longwave positive bands and shortwave negative bands $[58,59]$. The binding of a small, achiral molecule to a chiral DNA helix can result in induced CD signal from the molecule. 
Table 3. $\Delta T_{\mathrm{m}}$ of ct-DNA.

\begin{tabular}{|c|c|c|}
\hline \multirow[t]{2}{*}{ Compound } & $\Delta T_{\mathrm{m}}\left[{ }^{\circ} \mathrm{C}\right]$ & \multirow{2}{*}{$K_{b}\left[\mathbf{M}^{-1}\right]$} \\
\hline & ct-DNA & \\
\hline 6 & 1.50 & $2.00 \pm 1.90 \times 10^{5}$ \\
\hline 7 & -2.17 & $7.88 \pm 3.26 \times 10^{5}$ \\
\hline 8 & 1.50 & $1.40 \pm 1.04 \times 10^{5}$ \\
\hline 9 & 0.83 & $3.58 \pm 1.50 \times 10^{5}$ \\
\hline 10 & 0.50 & $2.48 \pm 1.44 \times 10^{5}$ \\
\hline 11 & 0.50 & $7.20 \pm 6.40 \times 10^{4}$ \\
\hline 15 & 0.50 & $2.40 \pm 1.0 \times 10^{4}$ \\
\hline 16 & 0.50 & $1.92 \pm 1.58 \times 10^{5}$ \\
\hline 17 & 0.83 & $2.17 \pm 1.10 \times 10^{5}$ \\
\hline 18 & -0.17 & $2.48 \pm 0.62 \times 10^{5}$ \\
\hline 19 & 0.17 & $3.88 \pm 0.38 \times 10^{5}$ \\
\hline 20 & -0.17 & $3.12 \pm 1.22 \times 10^{5}$ \\
\hline 31 & -1.17 & nd \\
\hline 32 & -0.83 & nd \\
\hline 33 & 0.50 & $2.06 \pm 1.80 \times 10^{5}$ \\
\hline 34 & 0.50 & $1.62 \pm 1.40 \times 10^{5}$ \\
\hline 35 & 0.17 & $1.98 \pm 1.58 \times 10^{5}$ \\
\hline 36 & 0.17 & $2.20 \pm 2.14 \times 10^{5}$ \\
\hline 39 & 1.50 & $3.62 \pm 1.10 \times 10^{5}$ \\
\hline 40 & 1.17 & $6.60 \pm 2.80 \times 10^{4}$ \\
\hline 41 & 0.83 & nd \\
\hline 42 & -0.17 & nd \\
\hline Mitonafide & 5.17 & $2.54 \times 10^{5}$ \\
\hline Pinafide & 6.50 & $6.60 \times 10^{4}$ \\
\hline
\end{tabular}

nd-not determined.

The CD spectrum of free ct-DNA showed a negative band at $248 \mathrm{~nm}$ due to polynucleotide helicity and a positive band at $276 \mathrm{~nm}$ due to base stacking, thus confirming the existence of ct-DNA in the right-band B-form [60]. As illustrated in Figure S172 (ESI), treatment with mitonafide and pinafide caused a decrease in the negative peak and an increase in the positive peak. In contrast, conjugates bearing boron cluster 6-11, 15-18, 20, 31, 32, and 34-36 did not cause any appreciable change in the CD spectra of ct-DNA (Figures S173-S183 (ESI)) with increase in concentration. In the case of compounds 19, 33,39 , and $40-42$, the positive and negative bands were perturbed by the presence of these ligands (Figures S176, S178, S180 and S181 (ESI)). This suggests that the compounds, especially 33 and 39, interact strongly with DNA but slightly weaker than mitonafide and pinafide. Naphthalimides bearing boron clusters at the $\mathrm{N}$-imide position also caused negligible stabilization of ct-DNA which was confirmed by the thermal melting experiment and CD spectra [20].

The interaction of naphthalimides containing carborane clusters was also studied by UV-vis absorption titration to better understand the mode of interaction and binding strength. Generally, bathochromic and hypochromic effects are observed in the absorption spectra if the small molecules intercalate with DNA [61]. The spectral changes observed in the electronic absorption of 6-11, 15-20, and 33-40 in the absence and presence of ct-DNA are illustrated in Figures S184-S203 (ESI). Progressive addition of ct-DNA at a concentration of 1.25-15 $\mu \mathrm{M}$ to a fixed amount of modified naphthalic anhydride or naphthalimide concentration $(20 \mu \mathrm{M})$ caused a decrease in absorbance for almost all the tested compounds, with an exception of conjugate $\mathbf{6}$ for which an increase of absorbance was observed. The most significant decrease in absorbance was recorded for conjugates 8 , $10,17-20,39$, and 40 with the low concentrations of ct-DNA (from 0 to $2.50 \mu \mathrm{M}$ ). However, we did not observe a significant shift of absorption maxima and only a slight bathochromic shift of about $2 \mathrm{~nm}$ was observed for compounds $\mathbf{1 6}$ and 39. This observation would rather indicate the groove binding of modified naphthalimide with ct-DNA, since insignificant 
(or small) shift in absorption spectral behavior (i.e., $\lambda^{\text {abs }}{ }_{\max }$ ) is generally accepted as the most probable consequence of groove binding [61]. On the other hand, the addition of ct-DNA to mitonafide caused a small bathochromic shift, which is also confirmed in the literature [62] (Figure S202 (ESI)). A quantitative rationalization of the drug-DNA binding strength is important to evaluate the efficacy of a drug or a therapeutic agent. Therefore, to compare the DNA binding strength of the tested molecules, we calculated the binding constant $\mathrm{K}_{b}$, as described in the Materials and Methods section.

In comparison with the available literature reports on intercalative binding of strong intercalators such as ethidium bromide [62], we observed (Table 3) a lower binding constant by one $(6-10,16-20,33-39)$ or two orders $(11,15,40)$ of magnitude. However, the selected modified compounds (6-10, 16-20, 33-39) showed a similar $K_{b}$ value compared to mitonafide, and some of the tested compounds $(\mathbf{1 1}, \mathbf{1 5}, \mathbf{4 0})$ revealed an analogous $\mathrm{K}_{b}$ value to pinafide (Table 3). For conjugates $31, \mathbf{3 2}, \mathbf{4 1}$, and $\mathbf{4 2}$, the $\mathrm{K}_{b}$ value could not be determined due to the lack of noticeable changes in the UV spectra.

\subsection{Similarity-Based Assessment of Property Profile}

The concept of intermolecular guest-host recognition in the quantitative receptorindependent structure-activity modeling (RI-QSAR) stems loosely from the straightforward tenet of the substituent similarity [63]. In general, a congeneric series of molecules should exhibit similar pharmacological profile because the interchangeable groups characterized by similar size, shape, or electronic distribution are likely to induce similar effects on binding affinities (neighbor behavior). Despite some limitations, the search for distancemediated similarity using a quantitative measure of the pairwise relatedness between two molecules, each with multidimensional $(\mathrm{mD})$ pool of attributes, contributes favorably to the ligand-based SAR practice [64]. Comparative molecular field analysis (CoMFA) integrated with computational chemistry as an in silico procedure has long been established in the field of computer-assisted molecular design [65]. CoMFA specifies the molecular features in the form of steric and/or electrostatic ligand patterns for superimposed molecules using the spatial distribution of noncovalent areas evaluated over the lattice of points. Masking the explicit shape information by the regularity of the cubic grid lattice allows translating the structural data into spatially uniform maps of potential ligand-receptor interactions (pharmacophore) [66].

We conducted a similarity-guided property space assessment for the ensemble of carborane-containing conjugates using the principal component analysis (PCA). In addition, the enhancement of planar descriptor-driven projection with response data resulted in a structure-activity landscape with a subtle picture of (dis)allowed structural adjustment(s) potentially valid for molecular activities. Finally, CoMFA was employed in the quantitative SAR ligand-based study to indicate the steric and/or electrostatic features of the pharmacophore pattern.

We evaluated the similarity-driven property for the congeneric set of structurally related naphthalimide-carborane conjugates using PCA on the pool of 2361 descriptors retrieved from Dragon 6.0 program-constant or nearly constant values with a standard deviation (SD) of $<10^{-4}$ were erased a priori. The $\mathrm{mD}$ data were organized into a matrix $X_{22 \times 2361}$ with rows and columns depicting molecules (objects) and descriptors (parameters), respectively. The standardized matrix was compressed effectively using PCA because the total variance described by the first three principal components (PCs) accounted for $82.87 \%$, indicating that the parameters were highly intercorrelated. We scrutinized the 3D space defined by the first orthogonal components (PC1 vs. PC2 vs. PC3), which revealed that carborane-based derivatives are basically clustered into four subgroups as shown in Figure 9. As expected, the positional isomers (ortho-/meta-) in the borane cluster were positioned together. 


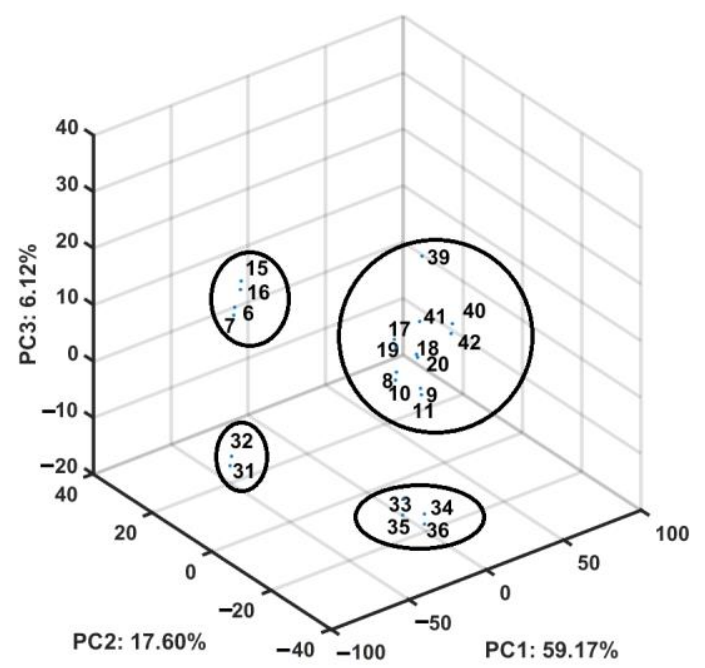

Figure 9. A 3D scoreplot of carborane-based conjugates.

Interestingly, the projection of the $\mathrm{IC}_{50}$ activity (expressed in the logarithmic scale) on the PC1 vs. PC2 plane clearly indicated the diagonal separation of the active $\left(\mathrm{pIC}_{50}>4.5\right)$ and nonactive $\left(\mathrm{pIC}_{50}<4.5\right)$ conjugates, as illustrated in Figure 10.

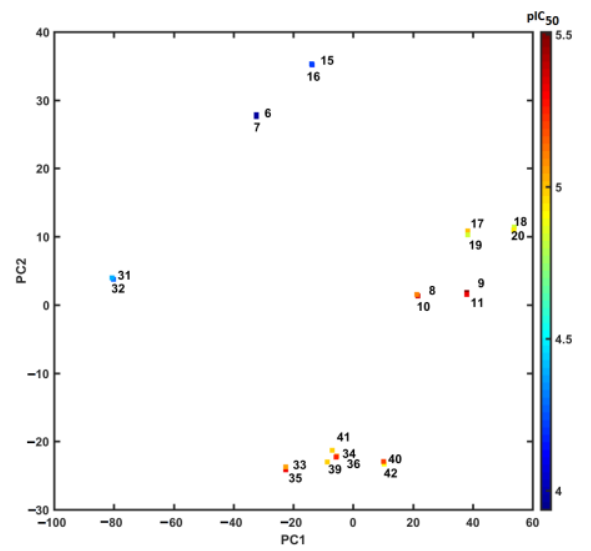

Figure 10. Projection of carborane-containing derivatives on the plane defined by the first vs. second principal component for Dragon descriptors with $\mathrm{IC}_{50}$ values in the logarithmic scale. Colors code the numerical values of $\mathrm{pIC}_{50}$.

On the other hand, a similar tendency was not observed for the projection of objects on the two-dimensional (PC1 vs. PC2) space that was color-coded by Lipinski's Rule of Five (Ro5) violations and molecular weights (MWs) accordingly. As a matter of fact, it was found that almost half of the analyzed carborane-containing conjugates did not strictly abide by Ro5 (Figure 11A) crossing the threshold value (MW $\leq 500)$ imposed on the MW descriptor (Figure 11B). Obviously, the violation of any two of the ADMET-friendly conditions reduces the probability of a compound to be orally bioavailable, whereas a good drug-like score does not make a molecule a drug (and vice versa) [67].

The gold standard of SAR-driven procedures is based on the similarity tenet, where the structural composition of chemicals influences their ADMET properties [68]. Despite the far-fetching over-simplification, the similarity concept conjugated with biological response is widely adopted in medicinal chemistry [69]. Conceptually, the pairwise descriptorbased structural relatedness between two objects can be quantitatively determined as a function of their common features, for instance using Tanimoto coefficient $\left(\mathrm{T}_{\mathrm{c}}\right)$ calculated for OpenBabel fingerprints. In this study, the distribution of this coefficient revealed a wide structural diversity of the analyzed molecules $\left(\Delta \mathrm{T}_{\mathrm{C}} \approx 0.45\right)$ with the greatest frequencies 
recorded at $0.58<\mathrm{T}_{\mathrm{c}}<0.68$, respectively, as depicted in Figure 12A. The lower values of $T_{c}$ in the deltoidal matrix $T_{22 \times 22}$, as shown in Figure 12B, indicated the structural dissimilarities within the analyzed molecules, thus confirming our previous PCA findings (Figure 9 or Figure 10).
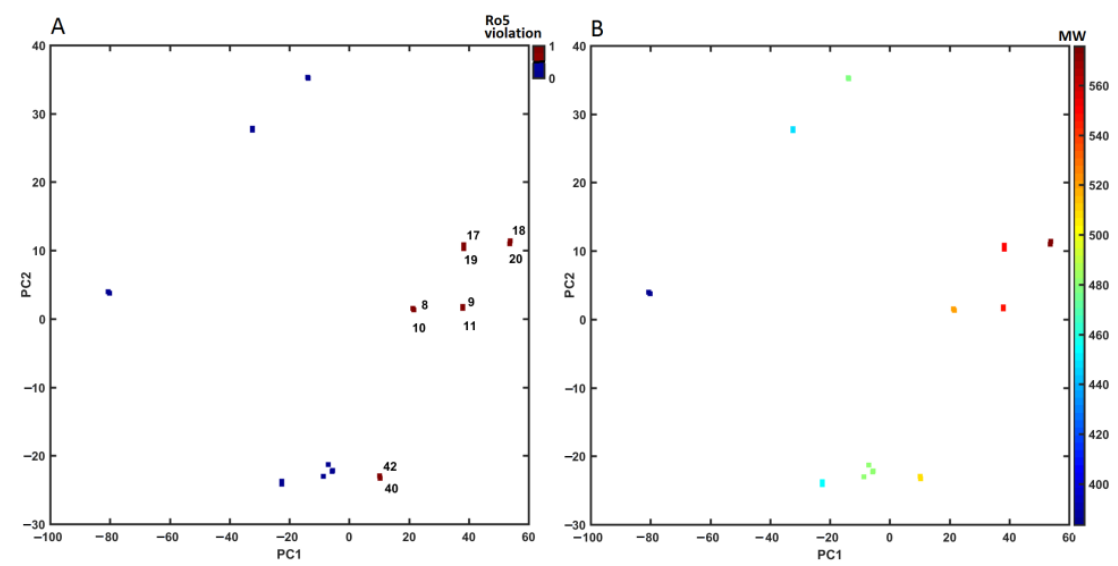

Figure 11. Projection of carborane-based derivatives on the plane defined by the first vs. second principal component for Dragon descriptors with violations of Ro5 (A) and calculated MW (B). Colors code the numerical values of Ro5 violations and MW.
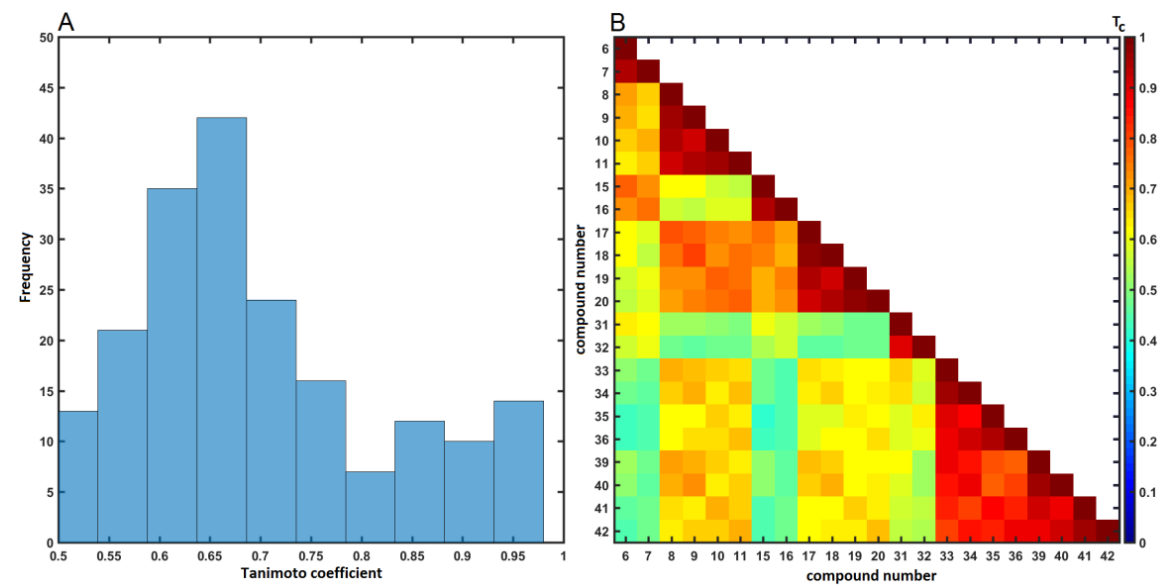

Figure 12. Distribution of $T_{C}$ coefficients (A) and triangular matrix of Tanimoto coefficients (B) for carborane conjugates.

The conjugation of structural pairwise comparison with response affinity profile results in a graphical map for systematically investigating the SAR trends in the form of structure-activity landscape index (SALI) [70]. The specification of continuity areas and/or activity cliffs is related to the availability of structurally similar compounds characterized by noticeable variations in the biological response. In fact, even sparse sampling of the factual chemical space can roughly determine the SAR areas with sharply nonuniform regions (magic methyl phenomenon). A symmetrical SALI grayscaled heat map is presented in Figure 13A, which shows that the studied molecules are sorted correspondingly to their $\mathrm{pIC}_{50}$ values, with the legend representing the numerical SALI values. 

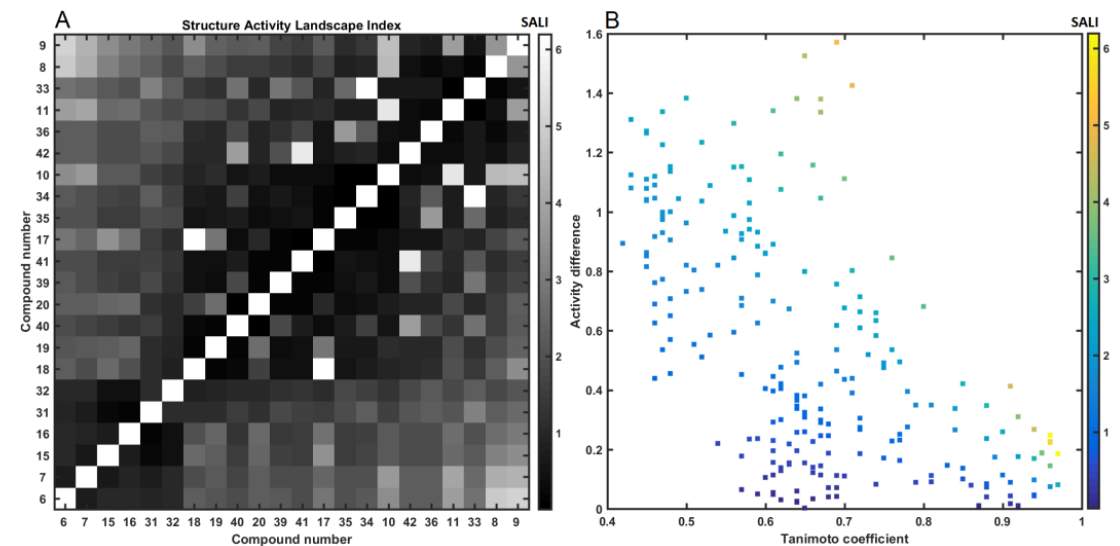

Figure 13. Grayscaled SALI plot with compounds ordered by increasing $\mathrm{pIC}_{50}$ values (A) and neighboring plot for carborane-based molecules (B).

Computationally, the structurally related molecules (e.g., positional stereoisomers, with $\mathrm{T} \rightarrow 1$ ) are characterized by SALI $\rightarrow$ infinity; therefore, such values were replaced by the highest (brightly color-coded) value of SALI. The right lower corner of the SALI plane (or the symmetrically positioned upper left one) was occupied by the most active molecules $(11,33,8,9)$ accompanied by nonactive molecules $(6,7,15,16)$, respectively. The bright SALI spots of the heat map in Figure 13A indicate that the specified molecules can potentially form activity cliff-Small structural variations are manifested via the demolition of activities.

Interestingly, the replacement of the anhydride-like fragment with the imide-based motif exerted a noticeable impact on molecular potency as revealed by our comparison between the most active and nonactive compounds $(11,33,8$ versus $6,7,15,16)$, respectively. Roughly speaking, it seems that the spatial arrangement of atoms/charges in the carborane cage (positional isomers) does not explain the variations observed in the biological response because nearly all active and nonactive molecules contain the same molecular borane-based scaffold attached to the hydrocarbon - $\left(\mathrm{CH}_{2}\right)_{3}$ - chain. In Figure 13B, the pairwise disparities of molecular activities are plotted against the structural (dis)similarities that are color-coded according to the SALI values. It appears that the sampling of structurally similar molecular pairs in the function of (un)favorable modifications ( $\mathrm{T} \geq 0.80$ and $\Delta \mathrm{pIC}_{50} \geq 1$ ) might be necessary to investigate the sparsely populated regions (rough areas) of the numerical SALI plane (the upper right corner in Figure 13B) and specify the SAR-related cliffs.

The modeling of biological/chemical effects of compounds and prediction of ADMETbased properties are challenging for contemporary in silico protocols. 3D-QSAR strategies, especially CoMFA, have greatly contributed to the specification of the spatial map of ligand-receptor interactions, namely pharmacophore mapping [71]. In fact, CoMFA allows constructing a spatially uniform 3D field around a series of superimposed molecules to investigate the molecular environment (steric/electronic features). Hence, the "indirect" ligand-based exploration of nonbinding fields (Lennard-Jones and Coulombic potentials) results in a 3D arrangement of the pharmacophoric properties of compounds sharing the common structural scaffold (chemotype). In this study, firstly, we subjected the superimposed training set of carborane-containing derivatives to CoMFA-the modeling of $\mathrm{pIC}_{50}$ data generated superior outcomes of the statistical metrics $\left(q_{c v}^{2}=0.87\right)$ for the $\mathrm{CH} 3+$ atom probe. Obviously, the robustness of the CoMFA model and its predictive power are strongly related to the separation of training/test subsets [72]. On the other hand, there are no specific rules for the selection of training/test subgroups; therefore, we chose the Duplex algorithm to generate a $16: 6$ training/test $(8,15,20,31,34,41)$ population, respectively. Only a slight deterioration of the model performance was observed $\left(q_{c v}^{2}=0.83\right)$ with a low standard error of prediction $(\mathrm{s}=0.244)$ for five optimal components. Interestingly, the results of CoMFA indicated that the steric field predominated the electrostatic one (fraction $0.82: 0.18)$. 
In reality, the direct translation of pharmacophore-based pattern into the corresponding pseudoreceptor model is not a trivial matter. In our study, the bundle of steric bulk was specified as privileged zones contributing (un)favorably to the ligand-based CoMFA model. Interestingly, the yellow 3D polyhedrals (Figure 14A) surrounding the carborane cage and the hydrocarbon chain attached with the triazole ring depicted the spatial areas marked as the unfavorable ones. In other words, the attachment of new substituents in the specified areas might have a detrimental impact on the activity of the carboranecontaining compounds. On the other hand, the dominant green spheres in the close proximity of the pyrrolidine ring (Figure 14A) suggested that modifications in this area might favorably affect the carborane-based derivatives. It vaguely confirms the tendency observed for the majority of the pyrrolidine-based and tertiary amine-like carborane conjugates; the activity profile can be roughly ranked as $\mathrm{pIC}_{50}$ (pyrrolidine) $>\mathrm{pIC}_{50}$ (tertiary amine). It seems that a nearly constant arrangement of charges within the rigid carborane cluster for the entire set of investigated compounds resulted in a low contribution of electrostatic potentials to the CoMFA model. The performance of this CoMFA model is illustrated graphically in Figure 14B, which shows the plot of actual versus predicted $\mathrm{pIC}_{50}$ values for the training (blue dots) and test (red dots) sets, respectively. The selected test population covered uniformly the structural space of the analyzed compounds as shown in Figure 14B. Due to the general lack of correlation between high $q_{c v}^{2}$ and the predictive ability of mD-QSAR models, Golbraikh and Tropsha criterion $\left(q_{c v}^{2}>0.5\right.$, $\left.R^{2}>0.6,\left[\frac{R^{2}-R_{0}^{2}}{R^{2}}\right]<0.1,0.85 \leq k \leq 1.15\right)$ was applied for the CoMFA model, which resulted in satisfactory statistical metrics: $R^{2}=0.89, R_{0}^{2}=0.99,\left[\frac{R^{2}-R_{0}^{2}}{R^{2}}\right]=-0.1, k=0.99$, $S D E P=0.14, M A E=0.12, q_{\text {test }}^{2}=0.88$ [73]
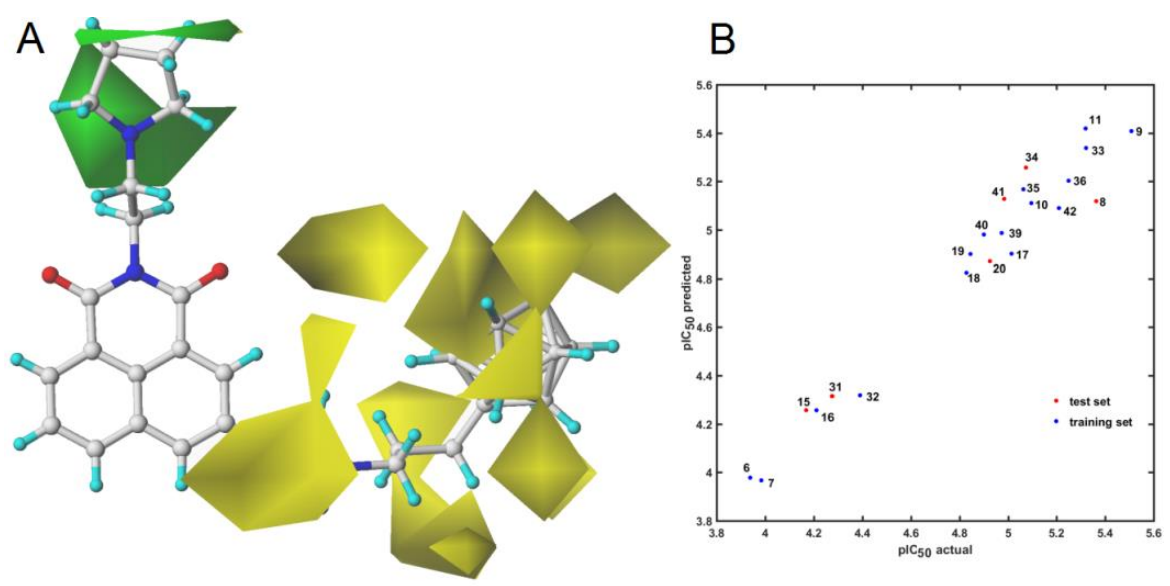

Figure 14. The favorable (green) and unfavorable (yellow) steric contributions with the most potent molecule 9 as a reference (A) and $\mathrm{pIC}_{50}$ actual vs. predicted plot for the training and test sets (B).

\section{Materials and Methods}

\subsection{Chemistry}

Most of the chemicals were obtained from the Acros Organics (Geel, Belgium) and were used without further purification unless otherwise stated. Boron clusters were pur-

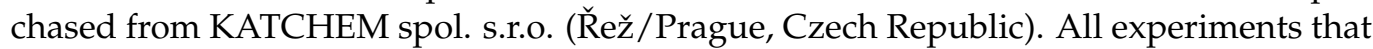
involved water-sensitive compounds were conducted under rigorously dry conditions and under an argon atmosphere. Flash column chromatography was performed on silica gel 60 (230-400 mesh, Sigma-Aldrich, Steinheim, Germany). $R_{\mathrm{f}}$ refer to analytical TLC performed using pre-coated silica gel 60 F254 plates purchased from Sigma-Aldric (Steinheim, Germany) and developed in the solvent system indicated. Compounds were visualized by use of UV light $(254 \mathrm{~nm})$ or a $0.5 \%$ acidic solution of $\mathrm{PdCl}_{2}$ in $\mathrm{HCl} /$ methanol by heating with a heat gun for boron-containing derivatives. The yields are not optimized. 
${ }^{1} \mathrm{H}-\mathrm{NMR},{ }^{13} \mathrm{C}-\mathrm{NMR}$, and ${ }^{11} \mathrm{~B}-\mathrm{NMR}$ spectra were recorded on an Avance III $600 \mathrm{MHz}$ spectrometer (Bruker, Billerica, MA, USA,) equipped with a direct ATM probe. The spectra for ${ }^{1} \mathrm{H},{ }^{13} \mathrm{C}$, and ${ }^{11} \mathrm{~B}-\mathrm{Nuclei}$ were recorded at $600.26 \mathrm{MHz}, 150.94 \mathrm{MHz}$, and $192.59 \mathrm{MHz}$, respectively. Deuterated solvents were used as standards. The following abbreviations are used to denote the multiplicities: $\mathrm{s}=$ singlet, $\mathrm{d}=$ doublet, $\mathrm{dd}=$ doublet of doublets, $\mathrm{ddd}=$ doublet of doublets of doublets, $\mathrm{t}=$ triplet, $\mathrm{dt}=$ doublet of triplets, $\mathrm{q}=$ quartet, quin $=$ quintet, $\mathrm{bs}=$ broad singlet, and $\mathrm{m}=$ multiplet. $J$ values are given in $\mathrm{Hz}$.

Mass spectra were recorded on a CombiFlash PurIon Model Eurus35 (Teledyne ISCO, Lincoln, NE, USA). The ionization was achieved by atmospheric-pressure chemical ionization (APCI) ionization in the positive ion mode (APCI+) and negative ion mode (APCI-). The entire flow was directed to the APCI ion source operating in the positive ion mode. Total ion chromatograms were recorded in the $\mathrm{m} / \mathrm{z}$ range of 100 to 700 . The vaporization and capillary temperature were set at $250-400$ and $200-300{ }^{\circ} \mathrm{C}$, respectively. Capillary voltage of $150 \mathrm{~V}$, corona discharge of $10 \mu \mathrm{A}$. High-resolution mass spectra (HRMS) were obtained on an Agilent 6546 LC/Q-TOF with ESI ion source spectrometer (Agilent Technologies, Inc., Santa Clara, CA, USA). The data are presented for the most abundant mass in the boron distribution plot of the base peak $(100 \%)$ and for the peak corresponding to the highest $\mathrm{m} / \mathrm{z}$ value with its relative abundance $(\%)$.

The theoretical molecular mass peaks of the compounds were calculated using the "Show Analysis Window" option in the ChemDraw Ultra 12.0 program. The calculated $\mathrm{m} / \mathrm{z}$ corresponds to the average mass of the compounds consisting of natural isotopes.

Infrared absorption spectra (IR) were recorded using a Nicolet 6700 Fourier-transform infrared spectrometer from Thermo Scientific (Runcorn, UK) equipped with an ETC EverGlo* source for the IR range, a Ge-on-KBr beam splitter, and a DLaTGS/KBr detector with a smart orbit sampling compartment and diamond window. The samples were placed directly on the diamond crystal, and pressure was added to make the surface of the sample conform to the surface of the diamond crystal.

UV measurements were performed using a GBC Cintra10 UV-VIS spectrometer (Dandenong, Australia). The samples used for the UV experiment were dissolved in $95 \%$ $\mathrm{C}_{2} \mathrm{H}_{5} \mathrm{OH}$. The measurement was performed at ambient temperature.

RP-HPLC analysis was performed on a Hewlett-Packard 1050 system equipped with a UV detector, and Hypersil Gold C18 column $(4.6 \times 250 \mathrm{~mm}, 5 \mu \mathrm{m}$ particle size, Thermo Scientific, Runcorn, UK). UV detection was conducted at $\lambda=340 \mathrm{~nm}$. The flow rate was $1 \mathrm{~mL} \mathrm{~min}^{-1}$. All analyses were run at ambient temperature. The gradient elution was as follows: gradient A-10 min from 30\% to $55 \%$ A, $10 \mathrm{~min}$ from $55 \%$ to $90 \% \mathrm{~A}$, and $10 \mathrm{~min}$ from $90 \%$ to $30 \% \mathrm{~A}$. Buffer A contained $0.1 \% \mathrm{HCOOH}$ in $\mathrm{CH}_{3} \mathrm{CN}$, and buffer $\mathrm{B}$ contained $0.1 \% \mathrm{HCOOH}$ in $\mathrm{H}_{2} \mathrm{O}$; gradient $\mathrm{B}-10 \mathrm{~min}$ from $0 \%$ to $25 \% \mathrm{~A}, 10 \mathrm{~min}$ from $25 \%$ to $60 \% \mathrm{~A}$ and $10 \mathrm{~min}$ from $60 \%$ to $0 \% \mathrm{~A}$. Buffer A contained $0.1 \% \mathrm{HCOOH}$ in $\mathrm{CH}_{3} \mathrm{CN}$, and buffer $\mathrm{B}$ contained $0.1 \% \mathrm{HCOOH}$ in $\mathrm{H}_{2} \mathrm{O}$. Crystals of 39 and 41 were obtained by slow evaporation from $\mathrm{MeOH}$. X-ray diffraction measurements on $\mathbf{3 9}$ were carried out under cryogenic conditions on beamline P13 equipped with PILATUS 6M detector, operated by EMBL Hamburg at the PETRA III storage ring (DESY, Hamburg, Germany). The data were processed using XDS [74], the structure was solved with SHELXT [75] and refined with SHELXL [76]. X-ray diffraction measurements on $\mathbf{4 1}$ were carried out under cryogenic conditions on SuperNova four-circle diffractometer (Oxford Diffraction, Abingdon, UK) equipped with a Cu anode and Atlas CCD detector. The data were processed with CRYSALISPRO software (Rigaku Oxford Diffraction) (Neu-Isenburg, Germany), the structure was solved with SHELXT and refined with SHELXL programs, as above, via the Olex ${ }^{2}$ interface [77]. The refinement of atomic positions was unrestrained except for hydrogen atoms which were maintained at riding positions. Table S2 (ESI) summarises the crystallographic data.

3-Iodonaphthalic anhydride (1) was synthesized as described in the literature [78]. Compound 1 was additionally purified by column chromatography on silica gel (230-400 mesh) using as an eluent $\mathrm{CH}_{2} \mathrm{Cl}_{2}$ to afford product as white solid. 1-(3-Azidopropyl)1,2-dicarba-closo-dodecaborane (4) and 1-(3-azidopropyl)-1,7-dicarba-closo-dodecaborane 
(5) were synthesized as described in the literature [23]. 3-Aminonaphthalic anhydride (12) was synthesized as described in the literature [26]. 3-Hydroxynaphthalic anhydride (13) was obtained analogously to the synthesis of 4-hydroxy-naphthalic anhydride [79]. Compounds 3-amino- $N$-[2-(dimethylamino)ethyl]-1,8-naphthalimide (21) and 3-amino- $N$ [2-(N-pyrrolidinyl)ethyl]-1,8-naphthalimide (22) were obtained in two steps: (1) synthesis of 3-aminonaphthalic anhydride (12) [26], (2) reaction with the appropriate amine $\mathrm{N}, \mathrm{N}$ dimethylethylenediamine (for compound 21) or $\mathrm{N}$-(2-aminoethyl)pyrrolidine (for compound 22) [27]. 2-(1,2-Dicarba-closo-dodecaboran-1-yl)ethanal (23) and 2-(1,7-dicarba-closododecaboran-1-yl)ethanal (24) were synthesized as described in the literature [28]. 3-(1,2Dicarba-closo-dodecaboran-1-yl)propionic acid (37) was synthesized as described in the literature [34]. 3-(1,7-Dicarba-closo-dodecaboran-1-yl)propionic acid (38) was synthesized as described in the literature [35].

\subsubsection{Synthesis of 3-Ethynyl-1,8-Naphthalic Anhydride (3)}

3-Iodo-1,8-naphthalic anhydride (1, $150 \mathrm{mg}, 462.8 \mu \mathrm{moL})$ was dissolved in anhydrous DMF (6 mL) and added to CuI (18 mg, $94.5 \mu \mathrm{moL})$, and $\mathrm{Pd}\left(\mathrm{PPh}_{3}\right)_{4}(54 \mathrm{mg}, 46.7 \mu \mathrm{moL})$. Next, anhydrous TEA $(130.5 \mu \mathrm{L}, 93.6 \mu \mathrm{moL})$ and trimethylsilylacetylene $(263.5 \mu \mathrm{L}, 1.85 \mathrm{mmoL})$ were added. Reaction mixture was stirred for $2 \mathrm{~h}$ at $65^{\circ} \mathrm{C}$ under an inert (Ar) atmosphere. Subsequently, the solvents were evaporated to dryness under vacuum and 3trimethylsilylethynyl-1,8-naphthalic anhydride (2) was purified by column chromatography on silica gel (230-400 mesh) using as an eluent $\mathrm{CH}_{2} \mathrm{Cl}_{2}$. Compound 2 (92 mg, $312.5 \mu \mathrm{moL})$ was dissolved in mixture of TFA $(5 \mathrm{~mL})$, THF $(800 \mu \mathrm{L})$ and $\mathrm{H}_{2} \mathrm{O}(800 \mu \mathrm{L})$. Reaction mixture was stirred for $8 \mathrm{~h}$ at RT and solvents were evaporated. The residue was dissolved in $\mathrm{CH}_{2} \mathrm{Cl}_{2}(5 \mathrm{~mL})$ and solvent was evaporated. This was was repeated twice. Crude product was purified by column chromatography on silica gel (230-400 mesh) using as an eluent $\mathrm{CH}_{2} \mathrm{Cl}_{2}$ to afford product as white solid. Yield: $51 \mathrm{mg}(50 \%)$. TLC $\left(\mathrm{CHCl}_{3}\right)$ : $R_{\mathrm{f}}=0.40 ;{ }^{1} \mathrm{H}-\mathrm{NMR}$ (acetone- $\left.\mathrm{d}_{6}, 600.26 \mathrm{MHz}\right): \delta(\mathrm{ppm})=8.68\left(\mathrm{~d}, 1 \mathrm{H}, J=1.5 \mathrm{~Hz}, \mathrm{H}_{\text {arom }}\right)$, $8.62\left(\mathrm{dd}, 1 \mathrm{H}, J=7.3,1.1 \mathrm{~Hz}, \mathrm{H}_{\text {arom }}\right), 8.56\left(\mathrm{~d}, 1 \mathrm{H}, J=8.3 \mathrm{~Hz}, \mathrm{H}_{\text {arom }}\right), 8.52(\mathrm{~d}, 1 \mathrm{H}, J=1.5 \mathrm{~Hz}$, $\left.\mathrm{H}_{\text {arom }}\right), 8.01\left(\mathrm{dd}, 1 \mathrm{H}, J=8.3,7.3 \mathrm{~Hz}, \mathrm{H}_{\text {arom }}\right), 4.04(\mathrm{~s}, 1 \mathrm{H}, \mathrm{C}-\mathrm{CH})$.

\subsubsection{Synthesis of 3-Prop-2-yn-1-yloxy-1,8-Naphthalic Anhydride (14)}

3-Hydroxy-1,8-naphthalic anhydride (13, $131.3 \mathrm{mg}, 613 \mu \mathrm{moL})$, propargyl alcohol $(38.9 \mu \mathrm{L}, 674.5 \mu \mathrm{moL})$ and $\mathrm{PPh}_{3}(193 \mathrm{mg}, 735.8 \mu \mathrm{moL})$ were suspended in anhydrous THF (1.3 mL). Suspension was cooled to $0^{\circ} \mathrm{C}$ under an inert atmosphere (Ar), and solution of DIAD $(144.5 \mu \mathrm{L}, 735.8 \mu \mathrm{moL})$ in anhydrous THF $(5.3 \mathrm{~mL})$ was added dropwise. Reaction mixture was stirred for $72 \mathrm{~h}$ at RT. Subsequently, water $(6.5 \mathrm{~mL})$ was added, and THF was evaporated. Crude product was extracted to $\mathrm{CH}_{2} \mathrm{Cl}_{2}(4 \times 5 \mathrm{~mL})$. The organic phase was separated, dried over $\mathrm{MgSO}_{4}$, filtered, and evaporated to dryness. The residue was purified by column chromatography on silica gel (230-400 mesh) using as an eluent $\mathrm{CH}_{2} \mathrm{Cl}_{2}$ to afford product as white solid. Yield: $108.4 \mathrm{mg}(70 \%)$. TLC $\left(\mathrm{CHCl}_{3}\right): R_{\mathrm{f}}=0.36 ;{ }^{1} \mathrm{H}-\mathrm{NMR}$ (acetone- $\left.\mathrm{d}_{6}, 600.26 \mathrm{MHz}\right): \delta(\mathrm{ppm})=8.45-8.44\left(\mathrm{~m}, 2 \mathrm{H}, 2 \mathrm{H}_{\text {arom }}\right), 8.21(\mathrm{~d}, 1 \mathrm{H}, J=2.5 \mathrm{~Hz}$, $\left.\mathrm{H}_{\text {arom }}\right), 8.07\left(\mathrm{~d}, 1 \mathrm{H}, J=2.4 \mathrm{~Hz}, \mathrm{H}_{\text {arom }}\right), 7.90\left(\mathrm{t}, 1 \mathrm{H}, J=7.8 \mathrm{~Hz}, \mathrm{H}_{\text {arom }}\right), 5.11(\mathrm{~d}, 2 \mathrm{H}, J=2.3 \mathrm{~Hz}$,

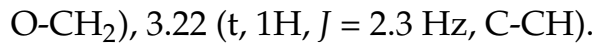

3.1.3. Synthesis of 1,8-Naphthalic Anhydride Derivatives 6, 7, and Naphthalimide Derivatives 8-11 Modified with Carborane Clusters via Click Reactions

1-(3-Azidopropyl)-carborane (ortho-carborane (4) or meta-carborane, (5)) (1 eqiuv.) was dissolved in mixture THF $/ \mathrm{H}_{2} \mathrm{O}(2.5: 1, v / v, 3 \mathrm{~mL}$ per $0.1 \mathrm{mmoL})$. 3-Ethynyl-1,8-naphthalic anhydride (3) (1 equiv.), $\mathrm{CuSO}_{4} 5 \mathrm{H}_{2} \mathrm{O}$ (0.05 equiv.) and sodium ascorbate (0.1 equiv.) were added. Reaction mixture was stirred for $2-4 \mathrm{~h}$ under argon at $35^{\circ} \mathrm{C}$. The reaction was quenched by evaporation of the solvents.

3-\{1-[3-(1,2-Dicarba-closo-dodecaborane-1-yl) propyl]-1H-1,2,3-triazol-4-yl\}-1,8-naphthalic anhydride (6): white solid, yield $12.2 \mathrm{mg}(60 \%)$. TLC $\left(\mathrm{MeOH} / \mathrm{CH}_{2} \mathrm{Cl}_{2}, 1: 49, v / v\right): R_{\mathrm{f}}=0.28$; ${ }^{1} \mathrm{H}-\mathrm{NMR}(\mathrm{DMSO}, 600.26 \mathrm{MHz}): \delta(\mathrm{ppm})=8.98\left(\mathrm{~d}, 1 \mathrm{H}, J=1.2 \mathrm{~Hz}, \mathrm{H}_{\text {arom }}\right), 8.96(\mathrm{~s}, 1 \mathrm{H}$, $\left.\mathrm{CH}_{\text {triazole }}\right), 8.90\left(\mathrm{~d}, 1 \mathrm{H}, J=1.5 \mathrm{~Hz}, \mathrm{H}_{\text {arom }}\right), 8.58\left(\mathrm{~d}, 1 \mathrm{H}, J=8.1 \mathrm{~Hz}, \mathrm{H}_{\text {arom }}\right), 8.50(\mathrm{~d}, 1 \mathrm{H}, J=7.2$ 
$\left.\mathrm{Hz}, \mathrm{H}_{\text {arom }}\right), 7.93\left(\mathrm{t}, 1 \mathrm{H}, \mathrm{J}=7.8 \mathrm{~Hz}, \mathrm{H}_{\text {arom }}\right), 5.19$ (br s, $\left.1 \mathrm{H}, \mathrm{CH}_{\text {carborane }}\right), 4.47$ (t, 2H, J = 7.0 Hz, $\mathrm{CH}_{2}$-triazole), 2.40-2.37 (m, 2H, $\mathrm{CH}_{2}$-carborane), 2.13-2.08 (m, 2H, $\mathrm{CH}_{2}-\mathrm{CH}_{2}-\mathrm{CH}_{2}$ ), 3.0-1.5 $\left(\mathrm{m}, 10 \mathrm{H}, \mathrm{B}_{10} \mathrm{H}_{10}\right) ;{ }^{13} \mathrm{C}-\mathrm{NMR}(\mathrm{DMSO}, 150.95 \mathrm{MHz}): \delta(\mathrm{ppm})=160.49(1 \mathrm{C}, \mathrm{C} 11), 160.46(1 \mathrm{C}$, C12), 144.67 (1C, $\left.\mathrm{C}_{\text {triazole }}\right), 135.36-119.08$ (11C, 10C arom, $\left.\mathrm{CH}_{\text {triazole }}\right), 75.54$ (1C, $\left.\mathrm{C}_{\text {carborane }}\right)$,

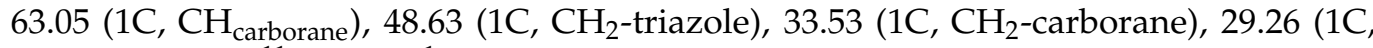
$\left.\mathrm{CH}_{2}-\mathrm{CH}_{2}-\mathrm{CH}_{2}\right) ;{ }^{11} \mathrm{~B}-\mathrm{NMR}\left\{{ }^{1} \mathrm{H} \mathrm{BB}\right\}(\mathrm{DMSO}, 192.59 \mathrm{MHz}): \delta(\mathrm{ppm})=-3.19$ (s, 1B, B9), -6.19 (s, 1B, B12), -9.77 (s, 2B, B8, 10), -11.64--13.11 (m, 6B, B3, 4, 5, 6, 7, 11); UV (99.8\% EtOH): $\lambda_{\max }(\mathrm{nm})=260,266,335, \lambda_{\min }=296, \lambda_{\mathrm{sh}}=320,367$; FT-IR: $v_{\max }\left(\mathrm{cm}^{-1}\right)=2964\left(\mathrm{C}-\mathrm{H}_{\text {aliphat }}\right)$, $2575(\mathrm{~B}-\mathrm{H}), 1770(\mathrm{C}=\mathrm{O}), 1733(\mathrm{C}=\mathrm{O}), 725(\mathrm{~B}-\mathrm{B})$; RP-HPLC (gradient A): $t_{\mathrm{R}}=18.23 \mathrm{~min}$; APCI-MS: $m / z: 450[\mathrm{M}+\mathrm{H}]^{+}, 492\left[\mathrm{M}+\mathrm{H}+\mathrm{CH}_{3} \mathrm{CN}\right]^{+}$, calcd for $\mathrm{C}_{19} \mathrm{H}_{23} \mathrm{~B}_{10} \mathrm{~N}_{3} \mathrm{O}_{3}: 449$.

3-\{1-[3-(1,7-Dicarba-closo-dodecaborane-1-yl)propyl]-1H-1,2,3-triazol-4-yl\}-1,8-naphthalic anhydride (7): white solid, yield $38.5 \mathrm{mg}$, (48\%). TLC $\left(\mathrm{MeOH} / \mathrm{CH}_{2} \mathrm{Cl}_{2}, 1: 49, v / v\right): R_{\mathrm{f}}=0.43$; ${ }^{1} \mathrm{H}-\mathrm{NMR}(\mathrm{DMSO}, 600.26 \mathrm{MHz}): \delta(\mathrm{ppm})=8.93\left(\mathrm{~s}, 2 \mathrm{H}, \mathrm{H}_{\text {arom }}\right.$ overlapped with $\left.\mathrm{CH}_{\text {triazole }}\right)$, $8.86\left(\mathrm{~d}, 1 \mathrm{H}, J=1.4 \mathrm{~Hz}, \mathrm{H}_{\text {arom }}\right), 8.54\left(\mathrm{~d}, 1 \mathrm{H}, J=8.1 \mathrm{~Hz}, \mathrm{H}_{\text {arom }}\right), 8.46(\mathrm{~d}, 1 \mathrm{H}, J=6.7 \mathrm{~Hz}$, $\left.\mathrm{H}_{\text {arom }}\right), 7.90\left(\mathrm{t}, 1 \mathrm{H}, J=7.7 \mathrm{~Hz}, \mathrm{H}_{\text {arom }}\right), 4.42\left(\mathrm{t}, 3 \mathrm{H}, J=6.9 \mathrm{~Hz}, \mathrm{CH}_{2}\right.$-triazole), 4.05 (br s, $\left.1 \mathrm{H}, \mathrm{CH}_{\text {carborane }}\right), 2.10-2.07\left(\mathrm{~m}, 2 \mathrm{H}, \mathrm{CH}_{2}\right.$-carborane), 2.00-1.97 (m, 2H, CH $2-\mathrm{CH}_{2}-\mathrm{CH}_{2}$ ), 3.0-1.5 (m, 10H, B $\left.{ }_{10} \mathrm{H}_{10}\right) ;{ }^{13} \mathrm{C}-\mathrm{NMR}$ (DMSO, $\left.150.95 \mathrm{MHz}\right): \delta(\mathrm{ppm})=160.41(1 \mathrm{C}, \mathrm{C} 11)$, 160.40 (1C, C12), 144.57 (1C, $\left.\mathrm{C}_{\text {triazole }}\right), 135.32-118.98$ (11C, 10C arom, $\left.\mathrm{CH}_{\text {triazole }}\right), 75.73$ (1C, $\left.\mathrm{C}_{\text {carborane }}\right), 56.30$ (1C, $\left.\mathrm{CH}_{\text {carborane }}\right), 48.75$ (1C, $\mathrm{CH}_{2}$-triazole), 32.83 (1C, $\mathrm{CH}_{2}$-carborane), $29.92\left(1 \mathrm{C}, \mathrm{CH}_{2}-\mathrm{CH}_{2}-\mathrm{CH}_{2}\right) ;{ }^{11} \mathrm{~B}-\mathrm{NMR}\left\{{ }^{1} \mathrm{H} \mathrm{BB}\right\}(\mathrm{DMSO}, 192.59 \mathrm{MHz}): \delta(\mathrm{ppm})=-4.57$ (s, 1B, B5), -11.09 (s, 5B, B4, 6, 9, 10, 12), -13.54 (s, 2B, B8, 11), -15.02 (s, 2B, B2, 3); UV $(99.8 \% \mathrm{EtOH}): \lambda_{\max }(\mathrm{nm})=261,266,334, \lambda_{\min }=296, \lambda_{\mathrm{sh}}=234,323,365 ;$ FT-IR: $\nu_{\max }\left(\mathrm{cm}^{-1}\right)$ = $2956\left(\mathrm{C}-\mathrm{H}_{\text {aliphat }}\right), 2594(\mathrm{~B}-\mathrm{H}), 1769(\mathrm{C}=\mathrm{O}), 1741(\mathrm{C}=\mathrm{O}), 724$ (B-B); RP-HPLC (gradient A): $t_{\mathrm{R}}=16.80 \mathrm{~min}$; APCI-MS: $m / z: 450[\mathrm{M}+\mathrm{H}]^{+}, 492\left[\mathrm{M}+\mathrm{H}+\mathrm{CH}_{3} \mathrm{CN}\right]^{+}$, calcd for $\mathrm{C}_{19} \mathrm{H}_{23} \mathrm{~B}_{10} \mathrm{~N}_{3} \mathrm{O}_{3}: 449$.

3-\{1-[3-(1,2-Dicarba-closo-dodecaborane-1-yl)propyl]-1H-1,2,3-triazol-4-yl\}-1,8-naphthalic anhydride (6) or 3-\{1-[3-(1,7-dicarba-closo-dodecaborane-1-yl)propyl]-1H-1,2,3-triazol-4-yl\}-1,8naphthalic anhydride (7) (1 equiv.) was dissolved in absolute EtOH (10 mL per $0.45 \mathrm{mmoL})$ and $N, N$-dimethylethylenediamine (1.1 equiv.) (for compound 8) or $N$-(2-aminoethyl) pyrrolidine (1.1 equiv.) (for compound 9) was added. The reaction mixture was stirred for $1 \mathrm{~h}$ at $35^{\circ} \mathrm{C}$ and then for $1 \mathrm{~h}$ at $45^{\circ} \mathrm{C}$ under an inert (Ar) atmosphere. Subsequently, the solvent was evaporated to dryness under vacuum and crude product was purified by column chromatography on silica gel (230-400 mesh) with a gradient of $\mathrm{MeOH}(0-10 \%)$ in $\mathrm{CH}_{2} \mathrm{Cl}_{2}$. Additionally (only for compound 11), purified product was dissolved in $\mathrm{CHCl}_{3}$ $(1 \mathrm{~mL})$ and poured into hexane $(5 \mathrm{~mL})$. A precipitate was isolated by centrifugation.

N-\{2-(Dimethylamino)ethyl]-3-[1-(1,2-dicarba-closo-dodecaborane-1-yl)propyl]-1H-1,2,3triazol-4-yl\}-1,8-naphthalimide (8): yellow solid, yield $9.5 \mathrm{mg}(41 \%)$ TLC (MeOH/CH $\mathrm{Cl}_{2}$, $1: 9, v / v): R_{\mathrm{f}}=0.29 ;{ }^{1} \mathrm{H}-\mathrm{NMR}\left(\right.$ acetone- $\left._{6}, 600.26 \mathrm{MHz}\right): \delta(\mathrm{ppm})=8.86(\mathrm{~d}, 1 \mathrm{H}, J=$ $\left.1.6 \mathrm{~Hz}, \mathrm{H}_{\text {arom }}\right), 8.76$ (d, 1H, J = $\left.1.5 \mathrm{~Hz}, \mathrm{H}_{\text {arom }}\right), 8.69$ (s, 1H, $\mathrm{CH}_{\text {triazole }}$ ), 8.45 (dd, $1 \mathrm{H}$, $\left.J=7.2,1.1 \mathrm{~Hz}, \mathrm{H}_{\text {arom }}\right), 8.37$ (d, $\left.1 \mathrm{H}, 8.2 \mathrm{~Hz}, \mathrm{H}_{\text {arom }}\right), 7.83\left(\mathrm{dd}, 1 \mathrm{H}, J=8.1,7.3 \mathrm{~Hz}, \mathrm{H}_{\text {arom }}\right.$ ), 4.73 (br s, $\left.1 \mathrm{H}, \mathrm{CH}_{\text {carborane }}\right), 4.61\left(\mathrm{t}, 2 \mathrm{H}, J=6.8 \mathrm{~Hz}, \mathrm{CH}_{2}\right.$-triazole), $4.28(\mathrm{t}, 2 \mathrm{H}, J=6.9 \mathrm{~Hz}$, $\left.\mathrm{CH}_{2}-\mathrm{N}(\mathrm{CO})_{2}\right), 2.67\left(\mathrm{t}, 2 \mathrm{H}, \mathrm{J}=6.9 \mathrm{~Hz}, \mathrm{CH}_{2}-\mathrm{N}\left(\mathrm{CH}_{3}\right)_{2}\right), 2.58-2.55\left(\mathrm{~m}, 2 \mathrm{H}, \mathrm{CH}_{2}\right.$-carborane), 2.33-2.30 (m, 8H, N( $\left.\mathrm{CH}_{3}\right)_{2}$ overlapped with $\left.\mathrm{CH}_{2}-\mathrm{CH}_{2}-\mathrm{CH}_{2}\right), 3.0-1.5\left(\mathrm{~m}, 10 \mathrm{H}, \mathrm{B}_{10} \mathrm{H}_{10}\right)$; ${ }^{13} \mathrm{C}-\mathrm{NMR}$ (acetone- $\left.\mathrm{d}_{6}, 150.95 \mathrm{MHz}\right): \delta(\mathrm{ppm})=164.60(1 \mathrm{C}, \mathrm{C} 11), 164.54(1 \mathrm{C}, \mathrm{C} 12), 146.82$ (1C, $\left.\mathrm{C}_{\text {triazole }}\right), 133.26-123.84$ (11C, 10C arom, $\left.\mathrm{CH}_{\text {triazole }}\right), 76.54$ (1C, $\left.\mathrm{C}_{\text {carborane }}\right), 63.82$ (1C, $\left.\mathrm{CH}_{\text {carborane }}\right), 57.95\left(1 \mathrm{C}, \mathrm{CH}_{2}-\mathrm{N}\left(\mathrm{CH}_{3}\right)_{2}\right), 50.13\left(1 \mathrm{C}, \mathrm{CH}_{2}\right.$-triazole $), 46.14\left(2 \mathrm{C}, 2 \times \mathrm{CH}_{3}\right), 38.92$ (1C, $\left.\mathrm{CH}_{2}-\mathrm{N}(\mathrm{CO})_{2}\right), 35.55$ (1C, $\mathrm{CH}_{2}$-carborane), $30.89\left(1 \mathrm{C}, \mathrm{CH}_{2}-\mathrm{CH}_{2}-\mathrm{CH}_{2}\right) ;{ }^{11} \mathrm{~B}-\mathrm{NMR}\left\{{ }^{1} \mathrm{H}\right.$ $\mathrm{BB}\}$ (acetone- $\left.\mathrm{d}_{6}, 192.59 \mathrm{MHz}\right): \delta(\mathrm{ppm})=-2.80(\mathrm{~s}, 1 \mathrm{~B}, \mathrm{~B} 9),-5.95(\mathrm{~s}, 1 \mathrm{~B}, \mathrm{~B} 12),-9.59(\mathrm{~s}, 2 \mathrm{~B}$, B8, 10), -11.53--11.80 (m, 4B, B3, 4, 5, 6), -12.98 (s, 2B, B7, 11); UV (99.8\% EtOH): $\lambda_{\max }$ $(\mathrm{nm})=257,338, \lambda_{\min }=295, \lambda_{\mathrm{sh}}=231,321,372 ;$ FT-IR: $v_{\max }\left(\mathrm{cm}^{-1}\right)=2942\left(\mathrm{C}-\mathrm{H}_{\text {aliphat }}\right), 2574$ (B-H), $1698(\mathrm{C}=\mathrm{O}), 1656(\mathrm{C}=\mathrm{O}), 722(\mathrm{~B}-\mathrm{B})$; RP-HPLC (gradient B): $t_{\mathrm{R}}=22.28 \mathrm{~min}$; APCI-MS: $m / z: 520[\mathrm{M}+\mathrm{H}]^{+}$, calcd for $\mathrm{C}_{23} \mathrm{H}_{33} \mathrm{~B}_{10} \mathrm{~N}_{5} \mathrm{O}_{2}=519 ; \mathrm{HRMS}(\mathrm{ESI}+) 520.3867[\mathrm{M}+\mathrm{H}]^{+}$, calcd for $\mathrm{C}_{23} \mathrm{H}_{33} \mathrm{~B}_{10} \mathrm{~N}_{5} \mathrm{O}_{2}=520.3711[\mathrm{M}+\mathrm{H}]^{+}$. 
N-[2-(N-Pyrrolidinyl)ethyl]-3-[1-(1,2-dicarba-closo-dodecaborane-1-yl)propyl]-1H-1,2,3triazol-4-yll-1,8-naphthalimide (9): yellow solid, yield $14.3 \mathrm{mg}$ (59\%). TLC (MeOH/ $\mathrm{CH}_{2} \mathrm{Cl}_{2}$, $1: 9, v / v): R_{\mathrm{f}}=0.27 ;{ }^{1} \mathrm{H}-\mathrm{NMR}\left(\right.$ acetone $\left.^{\mathrm{d}} \mathrm{d}_{6}, 600.26 \mathrm{MHz}\right): \delta(\mathrm{ppm})=8.84(\mathrm{~d}, 1 \mathrm{H}, J=1.5 \mathrm{~Hz}$, $\left.\mathrm{H}_{\text {arom }}\right), 8.74\left(\mathrm{~s}, 1 \mathrm{H}, \mathrm{H}_{\text {arom }}\right), 8.68\left(\mathrm{~s}, 1 \mathrm{H}, \mathrm{CH}_{\text {triazole }}\right), 8.44\left(\mathrm{~d}, 1 \mathrm{H}, J=7.2, \mathrm{~Hz}, \mathrm{H}_{\text {arom }}\right), 8.34(\mathrm{~d}$, $\left.1 \mathrm{H}, J=8.2 \mathrm{~Hz}, \mathrm{H}_{\text {arom }}\right), 7.81\left(\mathrm{t}, 1 \mathrm{H}, J=7.8 \mathrm{~Hz}, \mathrm{H}_{\text {arom }}\right), 4.73\left(\mathrm{br} \mathrm{s}, 1 \mathrm{H}, \mathrm{CH}_{\text {carborane }}\right), 4.60(\mathrm{dd}$, $2 \mathrm{H}, J=8.3,5.4 \mathrm{~Hz}, \mathrm{CH}_{2}$-triazole), $4.33\left(\mathrm{t}, 2 \mathrm{H}, J=6.8 \mathrm{~Hz}, \mathrm{CH}_{2}-\mathrm{N}(\mathrm{CO})_{2}\right), 2.95(\mathrm{t}, 2 \mathrm{H}, J=6.8 \mathrm{~Hz}$, $\mathrm{CH}_{2}$-pyrrolidine), 2.79 (br s, $\left.4 \mathrm{H}, \mathrm{N}-\mathrm{CH}_{2 \text { pyrrolidine }}-\mathrm{CH}_{2}\right), 2.58-2.56\left(\mathrm{~m}, 2 \mathrm{H}, \mathrm{CH}_{2}\right.$-carborane), 2.34-2.28 (m, $\left.2 \mathrm{H} \mathrm{CH}_{2}-\mathrm{CH}_{2}-\mathrm{CH}_{2}\right), 1.80$ (br s, $\left.4 \mathrm{H}, \mathrm{CH}_{2}-\mathrm{CH}_{2 \text { pyrrolidine }}-\mathrm{CH}_{2}\right), 3.0-1.5(\mathrm{~m}, 10 \mathrm{H}$, $\left.\mathrm{B}_{10} \mathrm{H}_{10}\right) ;{ }^{13} \mathrm{C}-\mathrm{NMR}$ (acetone- $\left.\mathrm{d}_{6}, 150.95 \mathrm{MHz}\right): \delta(\mathrm{ppm})=164.46(1 \mathrm{C}, \mathrm{C} 11), 164.40(1 \mathrm{C}, \mathrm{C} 12)$, 146.60 (1C, $\left.\mathrm{C}_{\text {triazole }}\right), 134.95-122.81$ (10C, 10C $\left.\mathrm{C}_{\text {arom }}, \mathrm{CH}_{\text {triazole }}\right), 76.36$ (10C, $\left.\mathrm{C}_{\text {carborane }}\right), 63.64$ (1C, $\left.\mathrm{CH}_{\text {carborane }}\right), 54.93$ (1C, N-CH $\left.\mathrm{CH}_{2 \text { prrolidine }}-\mathrm{CH}_{2}\right), 54.23$ (1C, $\mathrm{CH}_{2}$-pyrrolidine), 49.94 (1C, $\mathrm{CH}_{2}$-triazole), 39.41 (1C, $\left.\mathrm{CH}_{2}-\mathrm{N}(\mathrm{CO})_{2}\right), 35.36$ (1C, $\mathrm{CH}_{2}$-carborane), $30.68\left(1 \mathrm{C}, \mathrm{CH}_{2}-\mathrm{CH}_{2}-\right.$ $\left.\mathrm{CH}_{2}\right), 24.29\left(1 \mathrm{C}, \mathrm{CH}_{2}-\mathrm{CH}_{2}\right.$ pyrrolidine- $\left.\mathrm{CH}_{2}\right) ;{ }^{11} \mathrm{~B}-\mathrm{NMR}\left\{{ }^{1} \mathrm{H} \mathrm{BB}\right\}$ (acetone- $\left.\mathrm{d}_{6}, 192.59 \mathrm{MHz}\right): \delta$ $(\mathrm{ppm})=-2.80(\mathrm{~s}, 1 \mathrm{~B}, \mathrm{~B} 9),-5.95(\mathrm{~s}, 1 \mathrm{~B}, \mathrm{~B} 12),-9.60(\mathrm{~s}, 2 \mathrm{~B}, \mathrm{~B} 8,10),-11.54(\mathrm{~s}, 4 \mathrm{~B}, \mathrm{~B} 3,4,5$, 6), -13.03 (s, 2B, B7, 11); UV (99.8\% EtOH): $\lambda_{\max }=257,338 \mathrm{~nm}, \lambda_{\min }=296 \mathrm{~nm}, \lambda_{\mathrm{sh}}=238$, 323, $372 \mathrm{~nm}$; FT-IR: $v_{\max }\left(\mathrm{cm}^{-1}\right)=2960\left(\mathrm{C}-\mathrm{H}_{\text {aliphat }}\right), 2579(\mathrm{~B}-\mathrm{H}), 1698(\mathrm{C}=\mathrm{O}), 1659(\mathrm{C}=\mathrm{O})$, 723 (B-B), RP-HPLC (gradient B): $t_{\mathrm{R}}=21.84 \mathrm{~min}$; APCI-MS: $m / z: 547[\mathrm{M}+\mathrm{H}]^{+}$, calcd for $\mathrm{C}_{25} \mathrm{H}_{35} \mathrm{~B}_{10} \mathrm{~N}_{5} \mathrm{O}_{2}=546$.

N-\{2-(Dimethylamino)ethyl]-3-[1-(1,7-dicarba-closo-dodecaborane-1-yl)propyl]-1H-1,2,3triazol-4-yl\}-1,8-naphthalimide (10): yellow solid. Yield: $19.3 \mathrm{mg}(84 \%)$. TLC $\left(\mathrm{MeOH} / \mathrm{CH}_{2} \mathrm{Cl}_{2}\right.$, $1: 9, v / v): R_{\mathrm{f}}=0.33 ;{ }^{1} \mathrm{H}-\mathrm{NMR}\left(\mathrm{DMSO}-\mathrm{d}_{6}, 600.26 \mathrm{MHz}\right): \delta(\mathrm{ppm})=8.89\left(\mathrm{~s}, 1 \mathrm{H}, \mathrm{CH}_{\text {triazole }}\right)$, $8.85-8.83\left(\mathrm{~m}, 2 \mathrm{H}, 2 \mathrm{H}_{\text {arom }}\right), 8.45-8.41\left(\mathrm{~m}, 2 \mathrm{H}, 2 \mathrm{H}_{\text {arom }}\right), 7.84\left(\mathrm{t}, 1 \mathrm{H}, J=7.7 \mathrm{~Hz}, \mathrm{H}_{\text {arom }}\right), 4.42$ $\left(\mathrm{t}, 2 \mathrm{H}, J=6.7 \mathrm{~Hz}, \mathrm{CH}_{2}-\mathrm{N}(\mathrm{CO})_{2}\right), 4.16\left(\mathrm{t}, 2 \mathrm{H}, J=6.8 \mathrm{~Hz}, \mathrm{CH}_{2}\right.$-triazole), $4.05(\mathrm{br} \mathrm{s}, 1 \mathrm{H}$, $\left.\mathrm{CH}_{\text {carborane }}\right), 2.53\left(\mathrm{t}, 2 \mathrm{H}, \mathrm{J}=6.8 \mathrm{~Hz}, \mathrm{CH}_{2}-\mathrm{N}\left(\mathrm{CH}_{3}\right)_{2}\right), 2.22\left(\mathrm{~s}, 6 \mathrm{H}, 2 \mathrm{CH}_{3}\right), 2.09-2.07(\mathrm{~m}$, $2 \mathrm{H}, \mathrm{CH}_{2}$-carborane), $1.99-1.97\left(\mathrm{~m}, 2 \mathrm{H}, \mathrm{CH}_{2}-\mathrm{CH}_{2}-\mathrm{CH}_{2}\right), 3.0-1.5\left(\mathrm{~m}, 10 \mathrm{H}, \mathrm{B}_{10} \mathrm{H}_{10}\right) ;{ }^{13} \mathrm{C}-$ NMR (DMSO-d $\left.{ }_{6}, 150.95 \mathrm{MHz}\right): \delta(\mathrm{ppm})=163.17(1 \mathrm{C}, \mathrm{C} 11), 163.11(1 \mathrm{C}, \mathrm{C} 12), 144.98(1 \mathrm{C}$, $\left.\mathrm{C}_{\text {triazole }}\right), 134.25-121.97$ (11C, $\left.10 \mathrm{C}_{\text {arom }} \mathrm{CH}_{\text {triazole }}\right), 75.74$ (1C, $\left.\mathrm{C}_{\text {carborane }}\right), 56.42\left(1 \mathrm{C}, \mathrm{CH}_{2-}\right.$ $\left.\mathrm{N}\left(\mathrm{CH}_{3}\right)_{2}\right), 56.30\left(1 \mathrm{C}, \mathrm{CH}_{\text {carborane }}\right), 48.72\left(1 \mathrm{C}, \mathrm{CH}_{2}\right.$-triazole $), 45.30\left(2 \mathrm{C}, 2 \times \mathrm{CH}_{3}\right), 37.58(1 \mathrm{C}$, $\left.\mathrm{CH}_{2}-\mathrm{N}(\mathrm{CO})_{2}\right), 32.84$ (1C, $\mathrm{CH}_{2}$-carborane), $29.95\left(1 \mathrm{C}, \mathrm{CH}_{2}-\mathrm{CH}_{2}-\mathrm{CH}_{2}\right) ;{ }^{11} \mathrm{~B}-\mathrm{NMR}\left\{{ }^{1} \mathrm{H} \mathrm{BB}\right\}$ $\left(\right.$ DMSO-d $\left._{6}, 192.59 \mathrm{MHz}\right): \delta(\mathrm{ppm})=-4.62(\mathrm{~s}, 1 \mathrm{~B}, \mathrm{~B} 5),-11.11(\mathrm{~s}, 5 \mathrm{~B}, \mathrm{~B} 4,6,9,10,12),-13.58$ (s, 2B, B8, 11), -15.05 (s, 2B, B2, 3); UV (99.8\% EtOH): $\lambda_{\max }=257,339 \mathrm{~nm}, \lambda_{\min }=2978 \mathrm{~nm}$, $\lambda_{\text {sh }}=234,373 \mathrm{~nm}$; FT-IR: $v_{\max }\left(\mathrm{cm}^{-1}\right)=2953\left(\mathrm{C}-\mathrm{H}_{\text {aliphat }}\right), 2577(\mathrm{~B}-\mathrm{H}), 1698(\mathrm{C}=\mathrm{O}), 1655$ $(\mathrm{C}=\mathrm{O}), 722$ (B-B); RP-HPLC (gradient $\mathrm{B}$ ): $t_{\mathrm{R}}=22.20 \mathrm{~min}$; APCI-MS: $m / z: 520[\mathrm{M}+\mathrm{H}]^{+}$, calcd for $\mathrm{C}_{23} \mathrm{H}_{33} \mathrm{~B}_{10} \mathrm{~N}_{5} \mathrm{O}_{2}=519$.

N-[2-(N-Pyrrolidinyl)ethyl]-3-[1-(1,7-dicarba-closo-dodecaborane-1-yl)propyl]-1H-1,2,3triazol-4-yl\}-1,8-naphthalimide (11): white solid. Yield: $15 \mathrm{mg}$ (55\%). TLC (MeOH/ $\mathrm{CH}_{2} \mathrm{Cl}_{2}$, $1: 9, v / v): R_{\mathrm{f}}=0.34 ;{ }^{1} \mathrm{H}-\mathrm{NMR}\left(\mathrm{CDCl}_{3}, 600.26 \mathrm{MHz}\right): \delta(\mathrm{ppm})=8.83\left(\mathrm{~d}, 1 \mathrm{H}, J=1.5 \mathrm{~Hz}, \mathrm{H}_{\text {arom }}\right)$, $8.79\left(\mathrm{~d}, 1 \mathrm{H}, J=1,7 \mathrm{~Hz}, \mathrm{H}_{\text {arom }}\right), 8.54\left(\mathrm{dd}, 1 \mathrm{H}, J=7.2,0.8 \mathrm{~Hz}, \mathrm{H}_{\text {arom }}\right), 8.22(\mathrm{~d}, 1 \mathrm{H}, J=7.9 \mathrm{~Hz}$, $\left.\mathrm{H}_{\text {arom }}\right), 8.00\left(\mathrm{~s}, 1 \mathrm{H}, \mathrm{CH}_{\text {triazole }}\right), 7.74\left(\mathrm{t}, 1 \mathrm{H}, J=7.7 \mathrm{~Hz}, \mathrm{H}_{\text {arom }}\right), 4.43\left(\mathrm{t}, 2 \mathrm{H}, J=7.2 \mathrm{~Hz}, \mathrm{CH}_{2^{-}}\right.$ $\left.\mathrm{N}(\mathrm{CO})_{2}\right), 4.40\left(\mathrm{t}, 2 \mathrm{H}, J=6.2 \mathrm{~Hz}, \mathrm{CH}_{2}\right.$-triazole), 2.99 (br s, $2 \mathrm{H}, \mathrm{CH}_{2}$-pyrrolidine), 2.93 (br $\left.\mathrm{s}, 1 \mathrm{H}, \mathrm{CH}_{\text {carborane }}\right), 2.88$ (br s, $\left.4 \mathrm{H}, \mathrm{N}-\mathrm{CH}_{2 \text { pyrrolidine }}-\mathrm{CH}_{2}\right), 2.10-2.07\left(\mathrm{~m}, 4 \mathrm{H}, \mathrm{CH}_{2}-\mathrm{CH}_{2}-\mathrm{CH}_{2}\right.$ overlapped with $\mathrm{CH}_{2}$-carborane), 1.88 (br s, $\left.4 \mathrm{H}, \mathrm{CH}_{2}-\mathrm{CH}_{2 \text { pyrrolidine }}-\mathrm{CH}_{2}\right), 3.0-1.5(\mathrm{~m}, 10 \mathrm{H}$, $\left.\mathrm{B}_{10} \mathrm{H}_{10}\right) ;{ }^{13} \mathrm{C}-\mathrm{NMR}\left(\mathrm{CDCl}_{3}, 150.95 \mathrm{MHz} 0\right): \delta(\mathrm{ppm})=164.18(1 \mathrm{C}, \mathrm{C} 11), 164.15$ (1C C12), 146.58 (1C, $\left.\mathrm{C}_{\text {triazole }}\right), 134.45-120.71$ (11C, $\left.10 \mathrm{C}_{\text {arom }}, \mathrm{CH}_{\text {triazole }}\right), 74.72$ (1C, $\left.\mathrm{C}_{\text {carborane }}\right), 55.21$ (1C, $\left.\mathrm{CH}_{\text {carborane }}\right), 54.47$ (1C, N-CH $\left.\mathrm{CH}_{2 \text { rrolidine }}-\mathrm{CH}_{2}\right), 53.61$ (1C, $\mathrm{CH}_{2}$-pyrrolidine), 49.80 (1C, $\mathrm{CH}_{2}$-triazole), $38.70\left(1 \mathrm{C}, \mathrm{CH}_{2}-\mathrm{N}(\mathrm{CO})_{2}\right), 33.83\left(1 \mathrm{C}, \mathrm{CH}_{2}\right.$-carborane), $30.53\left(1 \mathrm{C}, \mathrm{CH}_{2}-\mathrm{CH}_{2}-\right.$ $\left.\mathrm{CH}_{2}\right), 23.79\left(1 \mathrm{C}, \mathrm{CH}_{2}-\mathrm{CH}_{2 \text { pyrrolidine }} \mathrm{CH}_{2}\right) ;{ }^{11} \mathrm{~B}-\mathrm{NMR}\left\{{ }^{1} \mathrm{H} \mathrm{BB}\right\}\left(\mathrm{CDCl}_{3}, 192.59 \mathrm{MHz}\right): \delta(\mathrm{ppm})$ $=-4.18(\mathrm{~s}, 1 \mathrm{~B}, \mathrm{~B} 5),-9.62(\mathrm{~s}, 1 \mathrm{~B}, \mathrm{~B} 12),-10.59--10.98(\mathrm{~m}, 4 \mathrm{~B}, \mathrm{~B} 4,6,9,10),-13.45(\mathrm{~s}$, 2B, B8, 11), -15.32 (s, 2B, B2, 3); UV (99.8\% EtOH): $\lambda_{\max }=257,338 \mathrm{~nm}, \lambda_{\min }=295 \mathrm{~nm}$, $\lambda_{\mathrm{sh}}=233,373 \mathrm{~nm}$; FT-IR: $v_{\max }\left(\mathrm{cm}^{-1}\right)=2956\left(\mathrm{C}-\mathrm{H}_{\text {aliphat }}\right), 2593(\mathrm{~B}-\mathrm{H}), 1698(\mathrm{C}=\mathrm{O}), 1660$ $(\mathrm{C}=\mathrm{O}), 730$ (B-B); RP-HPLC (gradient B): $t_{\mathrm{R}}=22.58 \mathrm{~min}$; APCI-MS: $m / z: 547[\mathrm{M}+\mathrm{H}]^{+}$, calcd for $\mathrm{C}_{25} \mathrm{H}_{35} \mathrm{~B}_{10} \mathrm{~N}_{5} \mathrm{O}_{2}=546$. 
3.1.4. Synthesis of 1,8-Naphthalic Anhydride Derivatives 15, 16, and Naphthalimide Derivatives 17-20 Modified with Carborane Clusterc via Click Reactions

1-(3-Azidopropyl)-carborane (ortho-carborane (4) or meta-carborane (5)) (1 equiv.) was dissolved in THF $/ \mathrm{H}_{2} \mathrm{O}$ (2.4:1, v/v, $2.5 \mathrm{~mL}$ per $\left.0.1 \mathrm{mmoL}\right)$. 3-(Prop-2-yn-1-yloxy)-1,8naphthalic anhydride (14) (1 equiv.), $\mathrm{CuSO}_{4} 5 \mathrm{H}_{2} \mathrm{O}(0.06$ equiv.) and sodium ascorbate ( 0.1 equiv.) were added. Reaction mixture was stirred for $3-4 \mathrm{~h}$ in $35^{\circ} \mathrm{C}$. For compound 15 after $1 \mathrm{~h}$ additional portion of $\mathrm{CuSO}_{4} \cdot 5 \mathrm{H}_{2} \mathrm{O}(0.06$ equiv.) and sodium ascorbate ( 0.1 equiv.) were added. The reaction was quenched by evaporation of the solvents. The crude compound was purified by column chromatography on silica gel (230-400 mesh) with a gradient of $\mathrm{MeOH}(0-5 \%)$ in $\mathrm{CH}_{2} \mathrm{Cl}_{2}$ as the eluent to afford product.

3-\{[1-(3-(1,2-Dicarba-closo-dodecaborane-1-yl)propyl)-1H-1,2,3-triazol-4-yl]methoxy\}-1,8naphthalic anhydride (15): white solid. Yield: $93.6 \mathrm{mg}(74 \%)$ TLC $\left(\mathrm{MeOH} / \mathrm{CH}_{2} \mathrm{Cl}_{2}, 1: 49\right.$, $v / v): R_{\mathrm{f}}=0.23 ;{ }^{1} \mathrm{H}-\mathrm{NMR}(\mathrm{DMSO}, 600.26 \mathrm{MHz}): \delta(\mathrm{ppm})=8.41\left(\mathrm{~d}, J=7.7 \mathrm{~Hz}, 1 \mathrm{H}, \mathrm{H}_{\text {arom }}\right)$, $8.37\left(\mathrm{dd}, J=7.2,1.0 \mathrm{~Hz}, 1 \mathrm{H}, \mathrm{H}_{\text {arom }}\right), 8.31\left(\mathrm{~s}, 1 \mathrm{H}, \mathrm{CH}_{\text {triazole }}\right), 8.17\left(\mathrm{~d}, J=2.6 \mathrm{~Hz}, 1 \mathrm{H}, \mathrm{H}_{\text {arom }}\right)$, $8.12\left(\mathrm{~d}, J=2.6 \mathrm{~Hz}, 1 \mathrm{H}, \mathrm{H}_{\text {arom }}\right), 7.87\left(\mathrm{dd}, J=8.1,7.3 \mathrm{~Hz}, 1 \mathrm{H}, \mathrm{H}_{\text {arom }}\right), 5.44\left(\mathrm{~s}, 2 \mathrm{H}, \mathrm{O}-\mathrm{CH}_{2}-\right.$

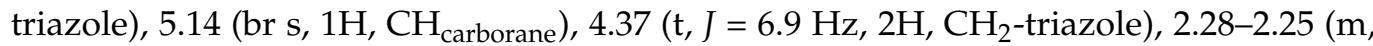
2H, $\mathrm{CH}_{2}$-carborane), 2.01-1.96 (m, 2H, $\left.\mathrm{CH}_{2}-\mathrm{CH}_{2}-\mathrm{CH}_{2}\right), 3.0-1.5\left(\mathrm{~m}, 10 \mathrm{H}, \mathrm{B}_{10} \mathrm{H}_{10}\right) ;{ }^{13} \mathrm{C}-\mathrm{NMR}$ $(\mathrm{DMSO}, 150.95 \mathrm{MHz}): \delta(\mathrm{ppm})=160.48(\mathrm{C} 11), 160.16$ (C12), 156.37 (C3), 142.07 (C triazole $_{\text {), }}$ 134.05-115.85 (9C arom $\left.+\mathrm{CH}_{\text {triazole }}\right), 75.42\left(\mathrm{C}_{\text {carborane }}\right), 62.85\left(\mathrm{CH}_{\text {carborane }}\right), 61.97\left(\mathrm{O}-\mathrm{CH}_{2}{ }^{-}\right.$ triazole), 48.25 ( $\mathrm{CH}_{2}$-triazole), $33.49\left(\mathrm{CH}_{2}\right.$-carborane), $29.34\left(\mathrm{CH}_{2}-\mathrm{CH}_{2}-\mathrm{CH}_{2}\right) ;{ }^{11} \mathrm{~B}-\mathrm{NMR}\{1 \mathrm{H}$ BB $(\mathrm{DMSO}, 192.59 \mathrm{MHz}): \delta(\mathrm{ppm})=-3.25(\mathrm{~s}, 1 \mathrm{~B}, \mathrm{~B} 9),-6.23(\mathrm{~s}, 1 \mathrm{~B}, \mathrm{~B} 12),-9.85(\mathrm{~s}, 2 \mathrm{~B}, \mathrm{~B} 8,10)$, $-11.76--13.13$ (m, 6B, B3,4,5,6,7,11); UV (99.8\% EtOH): $\lambda_{\max }=236.5,329.1,371.7 \mathrm{~nm}, \lambda_{\min }$ $=227.5,281.7,344.9 \mathrm{~nm}, \lambda_{\mathrm{sh}}=245.9,314.6 \mathrm{~nm}$; FT-IR: $v_{\max }\left(\mathrm{cm}^{-1}\right)=2924\left(\mathrm{C}-\mathrm{H}_{\text {aliphat }}\right)$, $2579(\mathrm{~B}-\mathrm{H}), 1770(\mathrm{C}=\mathrm{O}), 1732(\mathrm{C}=\mathrm{O}), 724(\mathrm{~B}-\mathrm{B})$; RP-HPLC (gradient A): $t_{\mathrm{R}}=17.61 \mathrm{~min}$; APCI-MS: $m / z: 480[\mathrm{M}+\mathrm{H}]^{+}, 513[\mathrm{M}+\mathrm{H}+\mathrm{MeOH}]^{+}, 522\left[\mathrm{M}+\mathrm{H}+\mathrm{CH}_{3} \mathrm{CN}\right]^{+}$, calcd for $\mathrm{C}_{20} \mathrm{H}_{25} \mathrm{~B}_{10} \mathrm{~N}_{3} \mathrm{O}_{4}=479$.

3-\{[1-(3-(1,7-Dicarba-closo-dodecaborane-1-yl)propyl)-1H-1,2,3-triazol-4-yl]methoxy\}-1,8naphthalic anhydride (16): white solid. Yield: $39 \mathrm{mg}(52 \%)$ TLC $\left(\mathrm{MeOH} / \mathrm{CH}_{2} \mathrm{Cl}_{2}, 1: 49\right.$, $v / v): R_{\mathrm{f}}=0.30 ;{ }^{1} \mathrm{H}-\mathrm{NMR}(\mathrm{DMSO}, 600.26 \mathrm{MHz}): \delta(\mathrm{ppm})=8.41\left(\mathrm{~d}, 1 \mathrm{H}, J=8.3 \mathrm{~Hz}, \mathrm{H}_{\text {arom }}\right)$, $8.37\left(\mathrm{~d}, 1 \mathrm{H}, J=7.2 \mathrm{~Hz}, \mathrm{H}_{\text {arom }}\right), 8.30\left(\mathrm{~s}, 1 \mathrm{H}, \mathrm{CH}_{\text {triazole }}\right), 8.17\left(\mathrm{~d}, 1 \mathrm{H}, J=2.4 \mathrm{~Hz}, \mathrm{H}_{\text {arom }}\right), 8.12$ $\left(\mathrm{d}, 1 \mathrm{H}, J=2.4 \mathrm{~Hz}, \mathrm{H}_{\text {arom }}\right), 7.87\left(\mathrm{dd}, 1 \mathrm{H}, J=8.1,7.5 \mathrm{~Hz}, \mathrm{H}_{\text {arom }}\right), 5.44$ (s, 2H, O-CH $\mathrm{CH}_{2}$-triazole), $4.33\left(\mathrm{t}, 2 \mathrm{H}, \mathrm{J}=6.7 \mathrm{~Hz}, \mathrm{CH}_{2}\right.$-triazole), 4.01 (br s, $1 \mathrm{H}, \mathrm{CH}_{\text {carborane }}$ ), $1.92-1.85$ (m, $4 \mathrm{H}, \mathrm{CH}_{2}-$ carborane overlapped with $\left.\mathrm{CH}_{2}-\mathrm{CH}_{2}-\mathrm{CH}_{2}\right), 3.0-1.5\left(\mathrm{~m}, 10 \mathrm{H}, \mathrm{B}_{10} \mathrm{H}_{10}\right) ;{ }^{13} \mathrm{C}-\mathrm{NMR}$ (DMSO, $150.95 \mathrm{MHz}): \delta(\mathrm{ppm})=160.52(1 \mathrm{C}, \mathrm{C} 11), 160.18(1 \mathrm{C}, \mathrm{C} 12), 156.35$ (1C, C3), 142.03 (1C, $\left.\mathrm{C}_{\text {triazole }}\right), 134.07-115.87$ (10C, 9C arom, $\left.\mathrm{CH}_{\text {triazole }}\right), 75.62$ (1C, $\left.\mathrm{C}_{\text {carborane }}\right), 61.94\left(1 \mathrm{C}, \mathrm{O}_{-} \mathrm{CH}_{2-}\right.$ triazole), 56.26 (1C, $\left.\mathrm{CH}_{\text {carborane }}\right), 48.39$ (1C, $\mathrm{CH}_{2}$-triazole), 32.72 (1C, $\mathrm{CH}_{2}$-carborane), 30.05 $\left(1 \mathrm{C}, \mathrm{CH}_{2}-\mathrm{CH}_{2}-\mathrm{CH}_{2}\right) ;{ }^{11} \mathrm{~B}-\mathrm{NMR}\left\{{ }^{1} \mathrm{H} \mathrm{BB}\right\}(\mathrm{DMSO}, 192.59 \mathrm{MHz}): \delta(\mathrm{ppm})=-4.56(\mathrm{~s}, 1 \mathrm{~B}, \mathrm{~B} 5)$, -11.16 (s, 5B, B4, 6, 9, 10, 12), -13.61 (s, 2B, B8, 11), -15.15 (s, 2B, B2, 3); UV (99.8\% EtOH): $\lambda_{\max }=235,328,372 \mathrm{~nm}, \lambda_{\min }=227,282,346 \mathrm{~nm}, \lambda_{\mathrm{sh}}=314,356 \mathrm{~nm}$; FT-IR: $\nu_{\max }\left(\mathrm{cm}^{-1}\right)=$ 2954 (C-H aliphat $_{\text {) }}, 2596(\mathrm{~B}-\mathrm{H}), 1771(\mathrm{C}=\mathrm{O}), 1733$ (C=O), 725 (B-B); RP-HPLC (gradient A): $t_{\mathrm{R}}$ $=17.42$ min; APCI-MS: $m / z: 480[\mathrm{M}+\mathrm{H}]^{+}, 513[\mathrm{M}+\mathrm{H}+\mathrm{MeOH}]^{+}, 522\left[\mathrm{M}+\mathrm{H}+\mathrm{CH}_{3} \mathrm{CN}\right]^{+}$, calcd for $\mathrm{C}_{20} \mathrm{H}_{25} \mathrm{~B}_{10} \mathrm{~N}_{3} \mathrm{O}_{4}=479$.

3-\{[1-(3-(1,2-Dicarba-closo-dodecaborane-1-yl)propyl)-1H-1,2,3-triazol-4-yl]methoxy\}-1,8naphthalic anhydride (15) or 3-\{[1-(3-(1,7-dicarba-closo-dodecaborane-1-yl) propyl)-1H-1,2,3triazol-4-yl]methoxy\}-1,8-naphthalic anhydride (16) (1 equiv.) was dissolved in absolute EtOH (10 mL per $0.45 \mathrm{mmoL})$ and $N, N$-dimethylethylenediamine (1.1 equiv.) or $N-(2-$ aminoethyl)pyrrolidine (1.1 equiv.) was added. The reaction mixture was stirred for $1 \mathrm{~h}$ at $35^{\circ} \mathrm{C}$, then for $1 \mathrm{~h}$ at $45^{\circ} \mathrm{C}$, under an inert (Ar) atmosphere. For compound 20 additional portion of $\mathrm{N}$-(2-aminoethyl)pyrrolidine (0.6 equiv.) were added and reaction mixture was stirred for $2 \mathrm{~h}$ in $45^{\circ} \mathrm{C}$. Subsequently, the solvent was evaporated to dryness under vacuum and crude product was purified by column chromatography on silica gel (230-400 mesh) with a gradient of $\mathrm{MeOH}(0-15 \%)$ in $\mathrm{CH}_{2} \mathrm{Cl}_{2}$. Additionally (for compound 18 and 20), purified product was dissolved in $\mathrm{CHCl}_{3}(0.5-1 \mathrm{~mL})$ and poured into hexane $(5-8 \mathrm{~mL})$. A precipitate was isolated by centrifugation. 
N-[2-(Dimethylamino)ethyl]-3-\{[1-(3-(1,2-dicarba-closo-dodecaborane-1-yl)propyl)-1H-1,2,3triazol-4-yl]metoxy\}-1,8-naphthalimide (17): yellow solid. Yield: $14.4 \mathrm{mg}(59 \%)$. TLC (MeOH/ $\left.\mathrm{CH}_{2} \mathrm{Cl}_{2}, 1: 9, v / v\right): R_{\mathrm{f}}=0.23 ;{ }^{1} \mathrm{H}-\mathrm{NMR}(\mathrm{DMSO}, 600.26 \mathrm{MHz}): \delta(\mathrm{ppm})=8.32-8.30(\mathrm{~m}$, $3 \mathrm{H}, 2 \mathrm{H}_{\text {arom }}$ overlapped with $\left.\mathrm{CH}_{\text {triazole }}\right), 8.07\left(\mathrm{~d}, 1 \mathrm{H}, \mathrm{J}=2.5 \mathrm{~Hz}, \mathrm{H}_{\text {arom }}\right), 8.05(\mathrm{~d}, 1 \mathrm{H}$, $\left.\mathrm{J}=2.5 \mathrm{~Hz}, \mathrm{H}_{\text {arom }}\right), 7.81\left(\mathrm{t}, 1 \mathrm{H}, \mathrm{J}=7.8 \mathrm{~Hz}, \mathrm{H}_{\text {arom }}\right), 5.41\left(\mathrm{~s}, 2 \mathrm{H}, \mathrm{O}-\mathrm{CH}_{2}\right.$-triazole), 5.13 (br $\left.\mathrm{s}, 1 \mathrm{H}, \mathrm{CH}_{\text {carborane }}\right), 4.37\left(\mathrm{t}, 2 \mathrm{H}, \mathrm{J}=6.9 \mathrm{~Hz}, \mathrm{CH}_{2}\right.$-triazole), $4.15\left(\mathrm{t}, 2 \mathrm{H}, \mathrm{J}=6.9 \mathrm{~Hz}, \mathrm{CH}_{2}-\right.$ $\left.\mathrm{N}(\mathrm{CO})_{2}\right), 2.57\left(\mathrm{t}, 2 \mathrm{H}, \mathrm{J}=6.7 \mathrm{~Hz}, \mathrm{CH}_{2}-\mathrm{N}\left(\mathrm{CH}_{3}\right)_{2}\right), 2.26-2.23\left(\mathrm{~m}, 8 \mathrm{H}, 2 \mathrm{~N}\left(\mathrm{CH}_{3}\right)_{2}\right.$ overlapped with $\mathrm{CH}_{2}$-carborane), $2.00-1.95\left(\mathrm{~m}, 2 \mathrm{H}, \mathrm{CH}_{2}-\mathrm{CH}_{2}-\mathrm{CH}_{2}\right), 3.0-1.5\left(\mathrm{~m}, 10 \mathrm{H}, \mathrm{B}_{10} \mathrm{H}_{10}\right) ;{ }^{13} \mathrm{C}-$ NMR (DMSO, $150.95 \mathrm{MHz}): \delta(\mathrm{ppm})=163.36$ (1C, C11), 162.91 (1C, C12), 156.27 (1C, C3), 142.24 (1C, $\left.\mathrm{C}_{\text {triazole }}\right), 133.02-114.70$ (10C, 9 $\left.\mathrm{C}_{\text {arom }}, \mathrm{CH}_{\text {triazole }}\right), 75.41$ (1C, $\left.\mathrm{C}_{\text {carborane }}\right), 62.84$ (1C, $\left.\mathrm{CH}_{\text {carborane }}\right), 61.84\left(1 \mathrm{C}, \mathrm{O}-\mathrm{CH}_{2}\right.$-triazole), $56.26\left(1 \mathrm{C}, \mathrm{CH}_{2}-\mathrm{N}\left(\mathrm{CH}_{3}\right)_{2}\right), 48.25\left(1 \mathrm{C}, \mathrm{CH}_{2}-\right.$ triazole), $45.10\left(2 \mathrm{C}, 2 \times \mathrm{CH}_{3}\right), 37.42\left(1 \mathrm{C}, \mathrm{CH}_{2}-\mathrm{N}(\mathrm{CO})_{2}\right), 33.49$ (1C, $\mathrm{CH}_{2}$-carborane), 29.35 $\left(1 \mathrm{C}, \mathrm{CH}_{2}-\mathrm{CH}_{2}-\mathrm{CH}_{2}\right) ;{ }^{11} \mathrm{~B}-\mathrm{NMR}\left\{{ }^{1} \mathrm{H} \mathrm{BB}\right\}(\mathrm{DMSO}, 192.59 \mathrm{MHz}): \delta(\mathrm{ppm})=-3.20(\mathrm{~s}, 1 \mathrm{~B}, \mathrm{~B} 9)$, -6.15 (s, 1B, B12), -9.82 (s, 2B, B8,10), -11.72--13.07 (m, 6B, B3, 4, 5, 6, 7, 11); UV (99.8\% EtOH): $\lambda_{\max }=238,334,375 \mathrm{~nm}, \lambda_{\min }=226,280,351 \mathrm{~nm}, \lambda_{\mathrm{sh}}=320 \mathrm{~nm}$; FT-IR: $v_{\max }\left(\mathrm{cm}^{-1}\right)$ $=2925\left(\mathrm{C}-\mathrm{H}_{\text {aliphat }}\right), 2594(\mathrm{~B}-\mathrm{H}), 1698(\mathrm{C}=\mathrm{O}), 1658(\mathrm{C}=\mathrm{O}), 723$ (B-B); RP-HPLC (gradient $\left.\mathrm{B}\right)$ : $t_{\mathrm{R}}=21.64 \mathrm{~min}$; APCI-MS: $\mathrm{m} / z: 550[\mathrm{M}+\mathrm{H}]^{+}$, calcd for $\mathrm{C}_{24} \mathrm{H}_{35} \mathrm{~B}_{10} \mathrm{~N}_{5} \mathrm{O}_{3}=549$.

N-[2-(N-Pyrrolidinyl)ethyl]-3-\{[1-(3-(1,2-dicarba-closo-dodecaborane-1-yl)propyl)-1H-1,2,3triazol-4-yl]metoxy\}-1,8-naphthalimide (18): white solid. Yield: $22.7 \mathrm{mg}$ (58\%). TLC (MeOH/ $\left.\mathrm{CH}_{2} \mathrm{Cl}_{2}, 1: 9, v / v\right): R_{\mathrm{f}}=0.24 ;{ }^{1} \mathrm{H}-\mathrm{NMR}\left(\mathrm{CDCl}_{3}, 600.26 \mathrm{MHz}\right): \delta(\mathrm{ppm})=8.40(\mathrm{~d}, 1 \mathrm{H}, \mathrm{J}=7.3 \mathrm{~Hz}$, $\left.\mathrm{H}_{\text {arom }}\right), 8.22\left(\mathrm{~d}, 1 \mathrm{H}, \mathrm{J}=2.6 \mathrm{~Hz}, \mathrm{H}_{\text {arom }}\right), 8.05\left(\mathrm{~d}, 1 \mathrm{H}, \mathrm{J}=8.1 \mathrm{~Hz}, \mathrm{H}_{\text {arom }}\right), 7.69\left(\mathrm{~s}, 1 \mathrm{H}, \mathrm{CH}_{\text {triazole }}\right)$, $7.67\left(\mathrm{t}, 1 \mathrm{H}, \mathrm{J}=7.5 \mathrm{~Hz}, \mathrm{H}_{\text {arom }}\right), 7.62\left(\mathrm{~d}, 1 \mathrm{H}, \mathrm{J}=2.4 \mathrm{~Hz}, \mathrm{H}_{\text {arom }}\right), 5.39\left(\mathrm{~s}, 2 \mathrm{H}, \mathrm{O}-\mathrm{CH}_{2}\right.$-triazole), 4.38-4.35 (m, $4 \mathrm{H}, \mathrm{CH}_{2}$-triazole overlapped with $\left.\mathrm{CH}_{2}-\mathrm{N}(\mathrm{CO})_{2}\right), 3.58$ (s, $\left.1 \mathrm{H}, \mathrm{CH}_{\text {carborane }}\right), 2.90$ (t, $2 \mathrm{H}, \mathrm{J}=7.1 \mathrm{~Hz}, \mathrm{CH}_{2}$-pyrrolidine), 2.77 (br s, $\left.4 \mathrm{H}, \mathrm{N}-\mathrm{CH}_{2 \text { pyrrolidine }}-\mathrm{CH}_{2}\right), 2.25-2.22(\mathrm{~m}, 2 \mathrm{H}$, $\mathrm{CH}_{2}$-carborane), 2.16-2.13 $\left(\mathrm{CH}_{2}-\mathrm{CH}_{2}-\mathrm{CH}_{2}\right), 1.83\left(\mathrm{~m}, 2 \mathrm{H}, \mathrm{CH}_{2}-\mathrm{CH}_{2 \text { pyrrolidine }}-\mathrm{CH}_{2}\right), 3.0-1.5$ $\left(\mathrm{m}, 10 \mathrm{H}, \mathrm{B}_{10} \mathrm{H}_{10}\right) ;{ }^{13} \mathrm{C}-\mathrm{NMR}\left(\mathrm{CDCl}_{3}, 150.95 \mathrm{MHz}\right): \delta(\mathrm{ppm})=164.22(1 \mathrm{C}, \mathrm{C} 11), 163.85(1 \mathrm{C}$, C12), 156.76 (1C, C3), 143.91 (1C, $\left.\mathrm{C}_{\text {triazole }}\right), 133.23-114.58$ (10C, 9C arom, $\left.\mathrm{CH}_{\text {triazole }}\right), 73.77$ (1C, $\left.\mathrm{C}_{\text {carborane }}\right), 62.68$ (1C, $\mathrm{O}-\mathrm{CH}_{2}$-triazole $), 61.78\left(1 \mathrm{C}, \mathrm{CH}_{\text {carborane }}\right), 54.50\left(1 \mathrm{C}, \mathrm{N}^{-} \mathrm{CH}_{2 \text { pyrrolidine }}\right.$ $\left.\mathrm{CH}_{2}\right), 53.71$ (1C, $\mathrm{CH}_{2}$-pyrrolidine), $49.28\left(1 \mathrm{C}, \mathrm{CH}_{2}\right.$-triazole), $38.99\left(1 \mathrm{C}, \mathrm{CH}_{2}-\mathrm{N}(\mathrm{CO})_{2}\right), 35.08$ (1C, $\mathrm{CH}_{2}$-carborane), $29.81\left(1 \mathrm{C}, \mathrm{CH}_{2}-\mathrm{CH}_{2}-\mathrm{CH}_{2}\right), 23.77\left(1 \mathrm{C}, \mathrm{CH}_{2}-\mathrm{CH}_{2 \text { pyrrolidine }}-\mathrm{CH}_{2}\right) ;{ }^{11} \mathrm{~B}$ $\mathrm{NMR}\left\{{ }^{1} \mathrm{H} \mathrm{BB}\right\}\left(\mathrm{CDCl}_{3}, 192.59 \mathrm{MHz}\right): \delta(\mathrm{ppm})=-2.15(\mathrm{~s}, 1 \mathrm{~B}, \mathrm{~B} 9),-5.45(\mathrm{~s}, 1 \mathrm{~B}, \mathrm{~B} 12),-9.17$ (s, 2B, B8, 10), -11.86--12.97 (m, 6B, B3, 4, 5, 6, 7, 11); UV (99.8\% EtOH): $\lambda_{\max }=239,335$, $374 \mathrm{~nm}, \lambda_{\min }=225,280,352 \mathrm{~nm}, \lambda_{\mathrm{sh}}=318 \mathrm{~nm}$; FT-IR: $v_{\max }\left(\mathrm{cm}^{-1}\right)=2926\left(\mathrm{C}-\mathrm{H}_{\text {aliphat }}\right), 2578$ (B-H), $1698(\mathrm{C}=\mathrm{O}), 1659$ (C=O), 723 (B-B); RP-HPLC (gradient B): $\mathrm{t}_{\mathrm{R}}=21.87 \mathrm{~min}$; APCI-MS: $m / z: 577[\mathrm{M}+\mathrm{H}]^{+}$, calcd for $\mathrm{C}_{26} \mathrm{H}_{37} \mathrm{~B}_{10} \mathrm{~N}_{5} \mathrm{O}_{3}=576$.

N-[2-(Dimethylamino)ethyl]-3-\{[1-(3-(1,7-dicarba-closo-dodecaborane-1-yl)propyl)-1H-1,2,3triazol-4-yl]metoxy\}-1,8-naphthalimide (19): yellow solid. Yield: $16.3 \mathrm{mg}(71 \%)$. TLC (MeOH/ $\left.\mathrm{CH}_{2} \mathrm{Cl}_{2}, 1: 9, v / v\right): R_{\mathrm{f}}=0.39 ;{ }^{1} \mathrm{H}-\mathrm{NMR}\left(\mathrm{CDCl}_{3}, 600.26 \mathrm{MHz}\right): \delta(\mathrm{ppm})=8.43(\mathrm{~d}, 1 \mathrm{H}, \mathrm{J}=7.2 \mathrm{~Hz}$, $\left.\mathrm{H}_{\text {arom }}\right), 8.26\left(\mathrm{~d}, 1 \mathrm{H}, \mathrm{J}=2.0 \mathrm{~Hz}, \mathrm{H}_{\text {arom }}\right), 8.08\left(\mathrm{~d}, 1 \mathrm{H}, \mathrm{J}=8.1 \mathrm{~Hz}, \mathrm{H}_{\text {arom }}\right), 7.69-7.64(\mathrm{~m}, 3 \mathrm{H}$, $2 \mathrm{H}_{\text {arom }}$ overlapped with $\left.\mathrm{CH}_{\text {triazole }}\right), 5.41\left(\mathrm{~s}, 2 \mathrm{H}, \mathrm{O}-\mathrm{CH}_{2}\right.$-triazole), $4.35(\mathrm{t}, 2 \mathrm{H}, \mathrm{J}=6.7 \mathrm{~Hz}$, $\left.\mathrm{CH}_{2}-\mathrm{N}(\mathrm{CO})_{2}\right), 4.30\left(\mathrm{t}, 2 \mathrm{H}, \mathrm{J}=6.1 \mathrm{~Hz}, \mathrm{CH}_{2}\right.$-triazole), 2.90 (br s, $\left.1 \mathrm{H}, \mathrm{CH}_{\text {carborane }}\right), 2.75$ (br s, $\left.2 \mathrm{H}, \mathrm{CH}_{2}-\mathrm{N}\left(\mathrm{CH}_{3}\right)_{2}\right), 2.42\left(\mathrm{~s}, 6 \mathrm{H}, \mathrm{N}\left(\mathrm{CH}_{3}\right)_{2}\right), 1.98-1.97\left(\mathrm{~m}, 4 \mathrm{H}, \mathrm{CH}_{2}-\mathrm{CH}_{2}-\mathrm{CH}_{2}\right.$ overlapped with $\mathrm{CH}_{2}$-carborane), 3.0-1.5 (m, $\left.10 \mathrm{H}, \mathrm{B}_{10} \mathrm{H}_{10}\right) ;{ }^{13} \mathrm{C}-\mathrm{NMR}\left(\mathrm{CDCl}_{3}, 150.95 \mathrm{MHz}\right): \delta(\mathrm{ppm})$ $=164.36(1 \mathrm{C}, \mathrm{C} 11), 163.96$ (1C, C12), 156.84 (1C, C3), 143.79 (1C, C triazole), 133.29-114.05 $\left(10 \mathrm{C}, 9 \mathrm{C}_{\text {arom }}, \mathrm{CH}_{\text {triazole }}\right), 74.65$ (1C, $\left.\mathrm{C}_{\text {carborane }}\right), 62.72$ (1C, O- $\mathrm{CH}_{2}$-triazole), 56.91 (1C, $\mathrm{CH}_{2}-$ $\left.\mathrm{N}\left(\mathrm{CH}_{3}\right)_{2}\right), 55.19$ (1C, $\left.\mathrm{CH}_{\text {carborane }}\right), 49.64\left(1 \mathrm{C}, \mathrm{CH}_{2}\right.$-triazole $), 45.56\left(2 \mathrm{C}, 2 \times \mathrm{CH}_{3}\right), 37.95(1 \mathrm{C}$, $\left.\mathrm{CH}_{2}-\mathrm{N}(\mathrm{CO})_{2}\right), 33.75$ (1C, $\mathrm{CH}_{2}$-carborane), $30.45\left(1 \mathrm{C}, \mathrm{CH}_{2}-\mathrm{CH}_{2}-\mathrm{CH}_{2}\right) ;{ }^{11} \mathrm{~B}-\mathrm{NMR}\left\{{ }^{1} \mathrm{H} \mathrm{BB}\right\}$ $\left(\mathrm{CDCl}_{3}, 192.59 \mathrm{MHz}\right): \delta(\mathrm{ppm})=-4.26(\mathrm{~s}, 1 \mathrm{~B}, \mathrm{~B} 5),-9.68(\mathrm{~s}, 1 \mathrm{~B}, \mathrm{~B} 12),-10.68--11.06(\mathrm{~m}, 4 \mathrm{~B}$, B4, 6, 9, 10), -13.49 (s, 2B, B8, 11), -15.38 (s, 2B, B2, 3); UV (99.8\% EtOH): $\lambda_{\max }=238,334$, $375 \mathrm{~nm}, \lambda_{\min }=225,283,351 \mathrm{~nm}, \lambda_{\mathrm{sh}}=319 \mathrm{~nm}$; FT-IR: $v_{\max }\left(\mathrm{cm}^{-1}\right)=2936\left(\mathrm{C}-\mathrm{H}_{\text {aliphat }}\right), 2595$ $(\mathrm{B}-\mathrm{H}), 1698(\mathrm{C}=\mathrm{O}), 1655(\mathrm{C}=\mathrm{O}), 731$ (B-B); RP-HPLC (gradient $\mathrm{B}): \mathrm{t}_{\mathrm{R}}=21.23$ min; APCI-MS: $m / z: 550[\mathrm{M}+\mathrm{H}]^{+}$, calcd for $\mathrm{C}_{24} \mathrm{H}_{35} \mathrm{~B}_{10} \mathrm{~N}_{5} \mathrm{O}_{3}=549$.

N-[2-(N-Pyrrolidinyl)ethyl]-3-\{[1-(3-(1,7-dicarba-closo-dodecaborane-1-yl)propyl)-1H-1,2,3triazol-4-yl]metoxy\}-1,8-naphthalimide (20): white solid. Yield: $28.3 \mathrm{mg}$ (83\%). TLC (MeOH/ 
$\left.\mathrm{CH}_{2} \mathrm{Cl}_{2}, 1: 9, v / v\right): R_{\mathrm{f}}=0.39 ;{ }^{1} \mathrm{H}-\mathrm{NMR}\left(\mathrm{CDCl}_{3}, 600.26 \mathrm{MHz}\right): \delta(\mathrm{ppm})=8.40(\mathrm{~d}, 1 \mathrm{H}$, $\left.\mathrm{J}=7.2 \mathrm{~Hz}, \mathrm{H}_{\text {arom }}\right), 8.23\left(\mathrm{~d}, 1 \mathrm{H}, \mathrm{J}=2.3 \mathrm{~Hz}, \mathrm{H}_{\text {arom }}\right), 8.05\left(\mathrm{~d}, 1 \mathrm{H}, \mathrm{J}=8.1 \mathrm{~Hz}, \mathrm{H}_{\text {arom }}\right), 7.66-$ $7.63\left(\mathrm{~m}, 3 \mathrm{H}, 2 \mathrm{H}_{\text {arom }}\right.$ overlapped with $\left.\mathrm{CH}_{\text {triazole }}\right), 5.40\left(\mathrm{~s}, 2 \mathrm{H}, \mathrm{O}-\mathrm{CH}_{2}\right.$-triazole $), 4.34(\mathrm{t}, 2 \mathrm{H}$, $\left.\mathrm{J}=7.2 \mathrm{~Hz}, \mathrm{CH}_{2}-\mathrm{N}(\mathrm{CO})_{2}\right), 4.30\left(\mathrm{t}, 2 \mathrm{H}, \mathrm{J}=6.4 \mathrm{~Hz}, \mathrm{CH}_{2}\right.$-triazole), 2.90 (br s, $1 \mathrm{H}, \mathrm{CH}_{\text {carborane }}$ ),

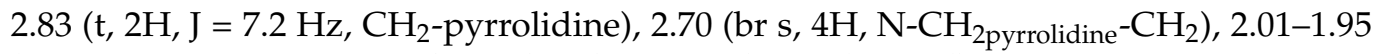
(m, $4 \mathrm{H}, \mathrm{CH}_{2}-\mathrm{CH}_{2}-\mathrm{CH}_{2}$ overlapped with $\mathrm{CH}_{2}$-carborane), 1.80 (br s, $4 \mathrm{H}, \mathrm{CH}_{2}-\mathrm{CH}_{2 \text { pyrrolidine }}$ $\left.\mathrm{CH}_{2}\right), 3.0-1.5\left(\mathrm{~m}, 10 \mathrm{H}, \mathrm{B}_{10} \mathrm{H}_{10}\right) ;{ }^{13} \mathrm{C}-\mathrm{NMR}\left(\mathrm{CDCl}_{3}, 150.95 \mathrm{MHz}\right): \delta(\mathrm{ppm})=164.22(1 \mathrm{C}$, C11), 163.80 (1C, C12), 156.81 (1C, C3), 143.76 (1C, C Criazole), 133.24-114.33 (10C, 9C arom, $\left.\mathrm{CH}_{\text {triazole }}\right), 74.64$ (1C, $\left.\mathrm{C}_{\text {carborane }}\right), 62.67$ (1C, $\mathrm{O}-\mathrm{CH}_{2}$-triazole), 55.18 (1C, $\left.\mathrm{CH}_{\text {carborane }}\right), 54.47$

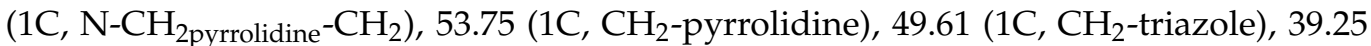
(1C, $\left.\mathrm{CH}_{2}-\mathrm{N}(\mathrm{CO})_{2}\right), 33.73\left(1 \mathrm{C}, \mathrm{CH}_{2}\right.$-carborane), $30.43\left(1 \mathrm{C}, \mathrm{CH}_{2}-\mathrm{CH}_{2}-\mathrm{CH}_{2}\right), 23.77\left(1 \mathrm{C}, \mathrm{CH}_{2}-\right.$ $\left.\mathrm{CH}_{2 \text { pyrrolidine }}-\mathrm{CH}_{2}\right) ;{ }^{11} \mathrm{~B}-\mathrm{NMR}\left\{{ }^{1} \mathrm{H} \mathrm{BB}\right\}\left(\mathrm{CDCl}_{3}, 192.59 \mathrm{MHz}\right): \delta(\mathrm{ppm})=-4.24(\mathrm{~s}, 1 \mathrm{~B}, \mathrm{~B} 5)$, -9.68 (s, 1B, B12), -10.64--11.06 (m, 4B, B4, 6, 9, 10), -13.49 (s, 2B, B8, 11), -15.38 (s, 2B, B2, 3); UV (99.8\% EtOH): $\lambda_{\max }=238,334,375 \mathrm{~nm}, \lambda_{\min }=226,286,351 \mathrm{~nm}, \lambda_{\mathrm{sh}}=319 \mathrm{~nm}$; FT-IR: $v_{\max }\left(\mathrm{cm}^{-1}\right)=2950\left(\mathrm{C}-\mathrm{H}_{\text {aliphat }}\right), 2595(\mathrm{~B}-\mathrm{H}), 1698(\mathrm{C}=\mathrm{O}), 1658(\mathrm{C}=\mathrm{O}), 731$ (B-B); RPHPLC (gradient B): $t_{R}=21.32$ min; APCI-MS: $m / z: 577[\mathrm{M}+\mathrm{H}]^{+}$, calcd for $\mathrm{C}_{26} \mathrm{H}_{37} \mathrm{~B}_{10} \mathrm{~N}_{5} \mathrm{O}_{3}$ = 576; HRMS (ESI+) $576.4156[\mathrm{M}+\mathrm{H}]^{+}$, calcd for $\mathrm{C}_{26} \mathrm{H}_{37} \mathrm{~B}_{10} \mathrm{~N}_{5} \mathrm{O}_{3}=576.3973[\mathrm{M}+\mathrm{H}]^{+}$.

3.1.5. Synthesis of 1,8-Naphthalic Anhydride Derivatives 31, 32 Modified with Carborane Cluster via Reductive Amination

3-Amino-1,8-naphthalic anhydride (12) (10-12.9 mg, 46.9-60.6 $\mu \mathrm{moL})$ was dissolved in anhydrous THF (0.9 mL) and 2-(1,2-dicarba-closo-dodecaborae-1-yl)ethanal (23) (1.3 equiv.) or 2-(1,7-dicarba-closo-dodecaborae-1-yl)ethanal (24) (1.2 equiv.) was added. The reaction mixture was stirred for $24 \mathrm{~h}$ at reflux under an inert (Ar) atmosphere. Next, to the Schiff base 25, $26 \mathrm{NaBH}_{3} \mathrm{CN}$ ( 3 equiv.) was added and reaction mixture was stirred for $24 \mathrm{~h}$ at $\mathrm{RT}$ under an inert (Ar) atmosphere. Subsequently, concentrated $\mathrm{HCl}$ (4-6 equiv.) was added and the reaction was stirred for additional $1 \mathrm{~h}$. Then the reaction mixture was diluted with brine (2-4 mL) and crude product was extracted with $\mathrm{CH}_{2} \mathrm{Cl}_{2}(3 \times 2-5 \mathrm{~mL})$. The organic phase was separated, dried over $\mathrm{MgSO}_{4}$, filtered, and evaporated to dryness. The residue was purified by column chromatography on silica gel (230-400 mesh) using as an eluent $\mathrm{CH}_{2} \mathrm{Cl}_{2}$ to afford product.

3-[(1,2-Dicarba-closo-dodecaborane-1-yl)ethylamino]-1,8-naphthalic anhydride (31): yellow solid. Yield: $16.3 \mathrm{mg}(62 \%)$. TLC $\left(2 \times \mathrm{CH}_{2} \mathrm{Cl}_{2}\right): R_{\mathrm{f}}=0.33 .{ }^{1} \mathrm{H}-\mathrm{NMR}\left(\mathrm{DMSO}-\mathrm{d}_{6}, 600.26 \mathrm{MHz}\right)$ : $\delta(\mathrm{ppm})=8.18\left(\mathrm{~d}, 1 \mathrm{H}, J=8.3 \mathrm{~Hz}, \mathrm{H}_{\text {arom }}\right), 8.11\left(\mathrm{~d}, 1 \mathrm{H}, J=7.2 \mathrm{~Hz}, \mathrm{H}_{\text {arom }}\right), 7.94(\mathrm{~d}, 1 \mathrm{H}$, $\left.J=2.4 \mathrm{~Hz}, \mathrm{H}_{\text {arom }}\right), 7.69\left(\mathrm{t}, 1 \mathrm{H}, J=7.7 \mathrm{~Hz}, \mathrm{H}_{\text {arom }}\right), 7.30\left(\mathrm{~d}, 1 \mathrm{H}, J=2.3 \mathrm{~Hz}, \mathrm{H}_{\text {arom }}\right), 6.67$ $(\mathrm{t}, 1 \mathrm{H}, J=5.5 \mathrm{~Hz}, \mathrm{NH}), 5.26$ (br s, $1 \mathrm{H}, \mathrm{CH}_{\text {carborane }}$ ), 3.32 (signal of $\mathrm{CH}_{2}-\mathrm{NH}$ overlapped with $\left.\mathrm{H}_{2} \mathrm{O}\right), 2.62\left(\mathrm{t}, 2 \mathrm{H}, J=7.5 \mathrm{~Hz}, \mathrm{CH}_{2}\right.$-carborane), 3.0-1.5 $\left(\mathrm{m}, 10 \mathrm{H}, \mathrm{B}_{10} \mathrm{H}_{10}\right) ;{ }^{13} \mathrm{C}-\mathrm{NMR}$ $\left(\right.$ DMSO-d $\left._{6}, 150.95 \mathrm{MHz}\right): \delta(\mathrm{ppm})=160.88$ (1C, C11), 160.79 (1C, C12), 146.75-109.25 (10C, $\left.10 \mathrm{C}_{\text {arom }}\right), 74.28$ (1C, $\left.\mathrm{C}_{\text {carborane }}\right), 62.94\left(1 \mathrm{C}, \mathrm{CH}_{\text {carborane }}\right), 41.79\left(1 \mathrm{C}, \mathrm{CH}_{2}-\mathrm{NH}\right), 34.94(1 \mathrm{C}$, $\mathrm{CH}_{2}$-carborane); ${ }^{11} \mathrm{~B}-\mathrm{NMR}\left\{{ }^{1} \mathrm{H} \mathrm{BB}\right\}\left(\mathrm{CDCl}_{3}, 192.59 \mathrm{MHz}\right): \delta(\mathrm{ppm})=-3.05(\mathrm{~s}, 1 \mathrm{~B}, \mathrm{~B} 9),-5.91$ (s, 1B, B12), -9.76 (s, 2B, B8,10), -11.45--13.06 (m, 6B, B3, 4, 5, 6, 7, 11); UV (99.8\% EtOH): $\lambda_{\max }=277,336,437 \mathrm{~nm}, \lambda_{\min }=239,305,359 \mathrm{~nm}$; FT-IR: $v_{\max }\left(\mathrm{cm}^{-1}\right)=2926\left(\mathrm{C}-\mathrm{H}_{\text {aliphat }}\right)$, $2587(\mathrm{~B}-\mathrm{H}), 1763(\mathrm{C}=\mathrm{O}), 1733(\mathrm{C}=\mathrm{O}), 724(\mathrm{~B}-\mathrm{B})$; RP-HPLC (gradient $\mathrm{A}): t_{\mathrm{R}}=18.50 \mathrm{~min}$; APCI-MS: $m / z: 384[\mathrm{M}+\mathrm{H}]^{+}, 416[\mathrm{M}+\mathrm{MeOH}+\mathrm{H}]^{+}$calcd for $\mathrm{C}_{16} \mathrm{H}_{21} \mathrm{~B}_{10} \mathrm{NO}_{3}=383$.

3-[(1,7-Dicarba-closo-dodecaborane-1-yl)ethylamino]-1,8-naphthalic anhydride (32): yellow solid. Yield: $9.8 \mathrm{mg}(55 \%)$. TLC $\left(2 \times \mathrm{CH}_{2} \mathrm{Cl}_{2}\right): R_{\mathrm{f}}=0.38 .{ }^{1} \mathrm{H}-\mathrm{NMR}\left(\mathrm{DMSO}-\mathrm{d}_{6}, 600.26 \mathrm{MHz}\right)$ : $\delta(\mathrm{ppm})=8.19\left(\mathrm{~d}, 1 \mathrm{H}, J=7.8 \mathrm{~Hz}, \mathrm{H}_{\text {arom }}\right), 8.11\left(\mathrm{dd}, 1 \mathrm{H}, J=7.2,0.9 \mathrm{~Hz}, \mathrm{H}_{\text {arom }}\right) 7.93(\mathrm{~d}, 1 \mathrm{H}$, $\left.J=2.4 \mathrm{~Hz}, \mathrm{H}_{\text {arom }}\right), 7.69\left(\mathrm{dd}, 1 \mathrm{H}, J=8.2,7.3 \mathrm{~Hz}, \mathrm{H}_{\text {arom }}\right), 7.27\left(\mathrm{~d}, 1 \mathrm{H}, J=2.3 \mathrm{~Hz}, \mathrm{H}_{\text {arom }}\right)$, $6.61(\mathrm{t}, 1 \mathrm{H}, J=5.5 \mathrm{~Hz}, \mathrm{NH}), 4.08\left(\mathrm{br} \mathrm{s}, 1 \mathrm{H}, \mathrm{CH}_{\text {carborane }}\right), 3.21(\mathrm{dd}, 2 \mathrm{H}, J=13.1,7.3 \mathrm{~Hz}$, $\left.\mathrm{CH}_{2}-\mathrm{NH}\right), 2.31\left(\mathrm{t}, 2 \mathrm{H}, J=7.5 \mathrm{~Hz}, \mathrm{CH}_{2}\right.$-carborane), 3.0-1.5 (m, $\left.10 \mathrm{H}, \mathrm{B}_{10} \mathrm{H}_{10}\right) ;{ }^{13} \mathrm{C}-\mathrm{NMR}$ (DMSO-d $\left.{ }_{6}, 150.95 \mathrm{MHz}\right): \delta(\mathrm{ppm})=160.92$ (1C, C11), 160.82 (1C, C12), 146.87-109.09 (10C, $\left.10 \mathrm{C}_{\text {arom }}\right), 74.33\left(1 \mathrm{C}, \mathrm{C}_{\text {carborane }}\right), 56.48\left(1 \mathrm{C}, \mathrm{CH}_{\text {carborane }}\right), 42.29\left(1 \mathrm{C}, \mathrm{CH}_{2}-\mathrm{NH}\right), 34.38\left(1 \mathrm{C}, \mathrm{CH}_{2}-\right.$ carborane); ${ }^{11} \mathrm{~B}-\mathrm{NMR}\left\{{ }^{1} \mathrm{H} \mathrm{BB}\right\}\left(\mathrm{DMSO}_{6}, \mathrm{~d}_{6} 192.59 \mathrm{MHz}\right): \delta(\mathrm{ppm})=-4.59(\mathrm{~s}, 1 \mathrm{~B}, \mathrm{~B} 5),-11.11$ $(\mathrm{s}, 5 \mathrm{~B}, \mathrm{~B} 4,6,9,10,12),-13.61--15.04(\mathrm{~m}, 4 \mathrm{~B}, \mathrm{~B} 2,3,8,11)$; UV (99.8\% EtOH): $\lambda_{\max }=279$, 
$336,439 \mathrm{~nm}, \lambda_{\min }=239,305,360 \mathrm{~nm}$; FT-IR: $v_{\max }\left(\mathrm{cm}^{-1}\right)=2926\left(\mathrm{C}-\mathrm{H}_{\text {aliphat }}\right), 2596(\mathrm{~B}-\mathrm{H})$, $1762(\mathrm{C}=\mathrm{O}), 1732(\mathrm{C}=\mathrm{O}), 724$ (B-B); RP-HPLC (gradient A): $t_{\mathrm{R}}=19.17 \mathrm{~min}$; APCI-MS: $m / z$ : $384[\mathrm{M}+\mathrm{H}]^{+}, 416[\mathrm{M}+\mathrm{MeOH}+\mathrm{H}]^{+}$calcd for $\mathrm{C}_{16} \mathrm{H}_{21} \mathrm{~B}_{10} \mathrm{NO}_{3}=383$.

3.1.6. Synthesis of Naphthalimide Derivatives 33-36 Modified with Carborane Cluster via Reductive Amination

3-Amino-N-[2-(dimethylamino)ethyl]-1,8-naphthalimide (21) (10-17.2 mg, 35.3-60.7 $\mu \mathrm{moL})$ or 3-amino-N-[2-(N-pyrrolidinyl)ethyl]-1,8-naphthalimide (22) (11-32 mg, 35.6-103.6 $\mu \mathrm{moL})$ was dissolved in anhydrous THF (14.9 mL per $1 \mathrm{mmoL}$ ) (for synthesis of compound $33,34)$ or in anhydrous $\mathrm{MeOH}(14 \mathrm{~mL}$ per $1 \mathrm{mmoL}$ ) (for synthesis of compound 35, 36) and 2-(1,2-dicarba-closo-dodecaborae-1-yl)ethanal (23) (1.3 equiv.) or 2-(1,7-dicarba-closododecaborae-1-yl)ethanal (24) (1.3 equiv.) was added. The reaction mixture was stirred for $24 \mathrm{~h}$ at reflux under an inert (Ar) atmosphere. Next, to the Schiff base $27-30 \mathrm{NaBH}_{3} \mathrm{CN}$ (3 equiv.) was added and reaction mixture was stirred for $24 \mathrm{~h}$ at RT under an inert (Ar) atmosphere. Subsequently, concentrated $\mathrm{HCl}$ (5-6 equv.) was added and the reaction was stirred for additional $1 \mathrm{~h}$. Then, the reaction mixture was diluted with brine $(57 \mathrm{~mL}$ per $1 \mathrm{mmoL})$ and crude product was extracted with $\mathrm{CH}_{2} \mathrm{Cl}_{2}(4 \times 2-10 \mathrm{~mL})$. The organic phase was separated, dried over $\mathrm{MgSO}_{4}$, filtered, and evaporated to dryness. Crude product was purified by column chromatography on silica gel (230-400 mesh) with a gradient of $\mathrm{MeOH}$ (3-14\%) in $\mathrm{CH}_{2} \mathrm{Cl}_{2}$ as the eluent to afford product.

N-[2-(Dimethylamino)ethyl]-3-[1,2-dicarba-closo-dodecaborane-1-yl)ethylamino]-1,8-naphthalimide (33): yellow solid. Yield: $15.7 \mathrm{mg}(57 \%)$. TLC $\left(\mathrm{MeOH} / \mathrm{CH}_{2} \mathrm{Cl}_{2}, 1: 9, v / v\right): R_{\mathrm{f}}=0.30 .{ }^{1} \mathrm{H}-$ NMR (DMSO-d $\left.{ }_{6}, 600.26 \mathrm{MHz}\right): \delta(\mathrm{ppm})=8.11-8.08\left(\mathrm{~m}, 2 \mathrm{H}, 2 \mathrm{H}_{\text {arom }}\right), 7.95(\mathrm{~d}, 1 \mathrm{H}, J=2.4 \mathrm{~Hz}$, $\left.\mathrm{H}_{\text {arom }}\right), 7.65\left(\mathrm{dd}, 1 \mathrm{H}, J=8.1,7.3 \mathrm{~Hz}, \mathrm{H}_{\text {arom }}\right), 7.23\left(\mathrm{~d}, 1 \mathrm{H}, J=2.4 \mathrm{~Hz}, \mathrm{H}_{\text {arom }}\right), 6.58(\mathrm{t}, 1 \mathrm{H}$, $J=5.7 \mathrm{~Hz}, \mathrm{NH}), 5.27$ (br s, $\left.1 \mathrm{H}, \mathrm{CH}_{\text {carborane }}\right), 4.12\left(\mathrm{t}, 2 \mathrm{H}, J=6.9 \mathrm{~Hz}, \mathrm{CH}_{2}-\mathrm{N}(\mathrm{CO})_{2}\right), 3.31$ (signal of $\mathrm{CH}_{2}-\mathrm{NH}$ overlapped with $\left.\mathrm{H}_{2} \mathrm{O}\right), 2.62\left(\mathrm{t}, 2 \mathrm{H}, \mathrm{J}=7.5 \mathrm{~Hz}, \mathrm{CH}_{2}\right.$-carborane), 2.50 (signal of $\mathrm{CH}_{2}-\mathrm{N}\left(\mathrm{CH}_{3}\right)_{2}$ overlapped with DMSO), $2.21\left(\mathrm{~s}, 6 \mathrm{H}, \mathrm{N}\left(\mathrm{CH}_{3}\right)_{2}\right), 3.0-1.5(\mathrm{~m}, 10 \mathrm{H}$, $\left.\mathrm{B}_{10} \mathrm{H}_{10}\right) ;{ }^{13} \mathrm{C}-\mathrm{NMR}\left(\mathrm{DMSO}_{6}, 150.95 \mathrm{MHz}\right): \delta(\mathrm{ppm})=163.68(1 \mathrm{C}, \mathrm{C} 11), 163.47(1 \mathrm{C}$, C12), 146.55-108.34 (10C, 10C arom), 74.33 (1C, $\left.\mathrm{C}_{\text {carborane }}\right), 62.94$ (1C, $\left.\mathrm{CH}_{\text {carborane }}\right), 56.45$ (1C, $\left.\mathrm{CH}_{2}-\mathrm{N}\left(\mathrm{CH}_{3}\right)_{2}\right), 45.30\left(2 \mathrm{C}, 2 \times \mathrm{CH}_{3}\right), 41.83\left(1 \mathrm{C}, \mathrm{CH}_{2}-\mathrm{NH}\right), 37.45,\left(1 \mathrm{C}, \mathrm{CH}_{2}-\mathrm{N}(\mathrm{CO})_{2}\right), 34.99$ $\left(\mathrm{CH}_{2 \text { carborane }}\right) ;{ }^{11} \mathrm{~B}-\mathrm{NMR}\left\{{ }^{1} \mathrm{H} \mathrm{BB}\right\}\left(\mathrm{DMSO}-\mathrm{d}_{6}, 192.59 \mathrm{MHz}\right): \delta(\mathrm{ppm})=-3.17(\mathrm{~s}, 1 \mathrm{~B}, \mathrm{~B} 9)$, -6.02 (s, 1B, B12), -9.82 (s, 2B, B8, 10), -11.62--13.11 (m, 6B, B3, 4, 5, 6, 7, 11); UV (99.8\% EtOH): $\lambda_{\max }=256,341,438 \mathrm{~nm}, \lambda_{\min }=236,312,366 \mathrm{~nm}, \lambda_{\mathrm{sh}}=280 \mathrm{~nm}$; FT-IR: $v_{\max }\left(\mathrm{cm}^{-1}\right)$ $=2973\left(\mathrm{C}-\mathrm{H}_{\text {aliphat }}\right), 2579(\mathrm{~B}-\mathrm{H}), 1704(\mathrm{C}=\mathrm{O}), 1651(\mathrm{C}=\mathrm{O}), 721$ (B-B); RP-HPLC (gradient B): $t_{\mathrm{R}}=22.36$ min; APCI-MS: $m / z: 454[\mathrm{M}+\mathrm{H}]^{+}$, calcd for $\mathrm{C}_{20} \mathrm{H}_{31} \mathrm{~B}_{10} \mathrm{~N}_{3} \mathrm{O}_{2}=453$.

$\mathrm{N}$-[2-(N-Pyrrolidinyl)ethyl]-3-[1,2-dicarba-closo-dodecaborane-1-yl)ethylamino]-1,8-naphthalimide (34): yellow solid. Yield: $23.5 \mathrm{mg}(47 \%)$. TLC $\left(\mathrm{MeOH} / \mathrm{CH}_{2} \mathrm{Cl}_{2}, 1: 9, v / v\right): R_{\mathrm{f}}=0.30 .{ }^{1} \mathrm{H}-\mathrm{NMR}$ (DMSO- $\left.\mathrm{d}_{6}, 600.26 \mathrm{MHz}\right): \delta(\mathrm{ppm})=8.12-8.09\left(\mathrm{~m}, 2 \mathrm{H}, 2 \mathrm{H}_{\text {arom }}\right), 7.96\left(\mathrm{~d}, 1 \mathrm{H}, J=2.4 \mathrm{~Hz}, \mathrm{H}_{\text {arom }}\right)$, $7.65\left(\mathrm{t}, 1 \mathrm{H}, J=7.8 \mathrm{~Hz}, \mathrm{H}_{\text {arom }}\right), 7.24\left(\mathrm{~d}, 1 \mathrm{H}, J=2.3 \mathrm{~Hz}, \mathrm{H}_{\text {arom }}\right), 6.59(\mathrm{t}, 1 \mathrm{H}, J=5.6 \mathrm{~Hz}, \mathrm{NH})$, 5.26 (br s, $1 \mathrm{H}, \mathrm{CH}_{\text {carborane }}$ ), $4.17\left(\mathrm{t}, 2 \mathrm{H}, \mathrm{J}=6.9 \mathrm{~Hz}, \mathrm{CH}_{2}-\mathrm{N}(\mathrm{CO})_{2}\right), 3.31$ (signal of $\mathrm{CH}_{2}-\mathrm{NH}$ overlapped with $\mathrm{H}_{2} \mathrm{O}$ ), 2.78 (br s, $2 \mathrm{H}, \mathrm{CH}_{2}$-pyrrolidine), 2.65-2.61 (m, 6H, N-CH $\mathrm{C}_{2 \text { prrolidine }}{ }^{-}$ $\mathrm{CH}_{2}$ overlapped with $\mathrm{CH}_{2}$-carborane), 1.70 (br s, $\left.4 \mathrm{H}, \mathrm{CH}_{2}-\mathrm{CH}_{2 \text { pyrrolidine }} \mathrm{CH}_{2}\right), 3.0-1.5(\mathrm{~m}$, $\left.10 \mathrm{H}, \mathrm{B}_{10} \mathrm{H}_{10}\right) ;{ }^{13} \mathrm{C}-\mathrm{NMR}\left(\mathrm{DMSO}-\mathrm{d}_{6}, 150.95 \mathrm{MHz}\right): \delta(\mathrm{ppm})=163.77(1 \mathrm{C}, \mathrm{C} 11), 163.55(1 \mathrm{C}$, C12), 146.57-108.37 (10C, 10C arom), 74.35 (1C, $\left.\mathrm{C}_{\text {carborane }}\right), 62.95$ (1C, $\left.\mathrm{CH}_{\text {carborane }}\right), 53.75$ (1C, $\left.\mathrm{N}-\mathrm{CH}_{2 \text { pyrrolidine }}-\mathrm{CH}_{2}\right), 52.92$ (1C, $\mathrm{CH}_{2}$-pyrrolidine), $41.83\left(1 \mathrm{C}, \mathrm{CH}_{2}-\mathrm{NH}\right), 38.21\left(1 \mathrm{C}, \mathrm{CH}_{2}-\right.$ $\left.\mathrm{N}(\mathrm{CO})_{2}\right), 34.99$ (1C, $\mathrm{CH}_{2}$-carborane), $23.11\left(1 \mathrm{C}, \mathrm{CH}_{2}-\mathrm{CH}_{2 \text { pyrrolidine }}-\mathrm{CH}_{2}\right) ;{ }^{11} \mathrm{~B}-\mathrm{NMR}\left\{{ }^{1} \mathrm{H} \mathrm{BB}\right\}$ $\left(\right.$ DMSO-d $\left._{6}, 192.59 \mathrm{MHz}\right): \delta(\mathrm{ppm})=-3.14(\mathrm{~s}, 1 \mathrm{~B}, \mathrm{~B} 9),-6.10(\mathrm{~s}, 1 \mathrm{~B}, \mathrm{~B} 12),-9.82--13.12(\mathrm{~m}$, $8 \mathrm{~B}, \mathrm{~B} 3,4,5,6,7,8,10,11)$; UV (99.8\% EtOH): $\lambda_{\max }=25,341,439 \mathrm{~nm}, \lambda_{\min }=236,314.4$, $366 \mathrm{~nm}, \lambda_{\mathrm{sh}}=280 \mathrm{~nm}$; FT-IR: $v_{\max }\left(\mathrm{cm}^{-1}\right)=2956\left(\mathrm{C}-\mathrm{H}_{\text {aliphat }}\right), 2576(\mathrm{~B}-\mathrm{H}), 1697(\mathrm{C}=\mathrm{O}), 1656$ $(\mathrm{C}=\mathrm{O}), 722$ (B-B), RP-HPLC (gradient B) $t_{\mathrm{R}}=22.83 \mathrm{~min}$; APCI-MS: $m / z: 480[\mathrm{M}+\mathrm{H}]^{+}$, calcd for $\mathrm{C}_{22} \mathrm{H}_{33} \mathrm{~B}_{10} \mathrm{~N}_{3} \mathrm{O}_{2}=479$.

N-[2-(Dimethylamino)ethyl]-3-[1,7-dicarba-closo-dodecaborane-1-yl)ethylamino]-1,8-naphthalimide (35): yellow solid. Yield: $11.7 \mathrm{mg}(73 \%)$. TLC $\left(\mathrm{MeOH} / \mathrm{CH}_{2} \mathrm{Cl}_{2}, 1: 9, v / v\right): R_{\mathrm{f}}=0.33 .{ }^{1} \mathrm{H}-$ $\operatorname{NMR}\left(\mathrm{CDCl}_{3}, 600.26 \mathrm{MHz}\right): \delta(\mathrm{ppm})=8.28\left(\mathrm{dd}, 1 \mathrm{H}, J=7.2,0.6 \mathrm{~Hz}, \mathrm{H}_{\text {arom }}\right), 7.92(\mathrm{~d}, 1 \mathrm{H}$, 
$\left.J=8.1 \mathrm{~Hz}, \mathrm{H}_{\text {arom }}\right), 7.88\left(\mathrm{~d}, 1 \mathrm{H}, J=2.4 \mathrm{~Hz}, \mathrm{H}_{\text {arom }}\right), 7.60\left(\mathrm{t}, 1 \mathrm{H}, J=7.7 \mathrm{~Hz}, \mathrm{H}_{\text {arom }}\right), 6.98(\mathrm{~d}$, $\left.1 \mathrm{H}, J=2.3 \mathrm{~Hz}, \mathrm{H}_{\text {arom }}\right), 4.35\left(\mathrm{t}, 2 \mathrm{H}, J=7.0 \mathrm{~Hz}, \mathrm{CH}_{2}-\mathrm{N}(\mathrm{CO})_{2}\right), 4.24(\mathrm{t}, 1 \mathrm{H}, J=5.7 \mathrm{~Hz}, \mathrm{NH})$, $3.31\left(\mathrm{dd}, 2 \mathrm{H}, J=13.6,7.2 \mathrm{~Hz}, \mathrm{CH}_{2}-\mathrm{NH}\right), 2.98\left(\mathrm{br} \mathrm{s}, 1 \mathrm{H}, \mathrm{CH}_{\text {carborane }}\right), 2.75(\mathrm{t}, 2 \mathrm{H}, J=6.7 \mathrm{~Hz}$, $\left.\mathrm{CH}_{2}-\mathrm{N}\left(\mathrm{CH}_{3}\right)_{2}\right), 2.43\left(\mathrm{~s}, 6 \mathrm{H}, \mathrm{N}\left(\mathrm{CH}_{3}\right)_{2}\right), 2.33\left(\mathrm{t}, 2 \mathrm{H}, J=7.5 \mathrm{~Hz}, \mathrm{CH}_{2}\right.$-carborane), 3.0-1.5 (m, $\left.10 \mathrm{H}, \mathrm{B}_{10} \mathrm{H}_{10}\right) ;{ }^{13} \mathrm{C}-\mathrm{NMR}\left(\mathrm{CDCl}_{3}, 150.95 \mathrm{MHz}\right): \delta(\mathrm{ppm})=164.65(1 \mathrm{C}, \mathrm{C} 11), 164.41(1 \mathrm{C}, \mathrm{C} 12)$, 145.79-109.83 (10C, 10C arom), 73.48 (1C, $\left.\mathrm{C}_{\text {carborane }}\right), 57.02\left(1 \mathrm{C}, \mathrm{CH}_{2}-\mathrm{N}\left(\mathrm{CH}_{3}\right)_{2}\right), 55.37(1 \mathrm{C}$, $\left.\mathrm{CH}_{\text {carborane }}\right), 45.66\left(2 \mathrm{C}, 2 \times \mathrm{CH}_{3}\right), 43.24\left(1 \mathrm{C}, \mathrm{CH}_{2}-\mathrm{NH}\right), 37.88,\left(1 \mathrm{C}, \mathrm{CH}_{2}-\mathrm{N}(\mathrm{CO})_{2}\right), 35.52$ (1C, $\mathrm{CH}_{2}$-carborane); ${ }^{11} \mathrm{~B}-\mathrm{NMR}\left\{{ }^{1} \mathrm{H} \mathrm{BB}\right\}\left(\mathrm{CDCl}_{3}, 192.59 \mathrm{MHz}\right): \delta(\mathrm{ppm})=-4.14(\mathrm{~s}, 1 \mathrm{~B}, \mathrm{~B} 5)$, $-9.43--10.87$ (m, 5B, B4, 6, 9, 10, 12), -13.37 (s, 2B, B8, 11), -15.19 (s, 2B, B2, 3); UV (99.8\% $\mathrm{EtOH}): \lambda_{\max }=257,341,440 \mathrm{~nm}, \lambda_{\min }=236,314,367 \mathrm{~nm}, \lambda_{\mathrm{sh}}=280 \mathrm{~nm}$; FT-IR: $v_{\max }\left(\mathrm{cm}^{-1}\right)$ $=2953\left(\mathrm{C}-\mathrm{H}_{\text {aliphat }}\right), 2598(\mathrm{~B}-\mathrm{H}), 1703(\mathrm{C}=\mathrm{O}), 1655(\mathrm{C}=\mathrm{O}), 729$ (B-B); RP-HPLC O (gradient B): $t_{\mathrm{R}}=22.52 \mathrm{~min}$; APCI-MS: $m / z: 454[\mathrm{M}+\mathrm{H}]^{+}$, calcd for $\mathrm{C}_{20} \mathrm{H}_{31} \mathrm{~B}_{10} \mathrm{~N}_{3} \mathrm{O}_{2}=453$; HRMS (ESI+) $454.3642[\mathrm{M}+\mathrm{H}]^{+}$, calcd for $\mathrm{C}_{20} \mathrm{H}_{31} \mathrm{~B}_{10} \mathrm{~N}_{3} \mathrm{O}_{2}=454.3493[\mathrm{M}+\mathrm{H}]^{+}$.

$\mathrm{N}$-[2-(N-Pyrrolidinyl)ethyl]-3-[1,7-dicarba-closo-dodecaborane-1-yl)ethylamino]-1,8-naphthalimide (36): yellow solid. Yield: $12.5 \mathrm{mg}(74 \%)$. TLC $\left(\mathrm{MeOH} / \mathrm{CH}_{2} \mathrm{Cl}_{2}, 1: 9, v / v\right): R_{\mathrm{f}}=0.33$ ${ }^{1} \mathrm{H}-\mathrm{NMR}\left(\mathrm{CDCl}_{3}, 600.26 \mathrm{MHz}\right): \delta(\mathrm{ppm})=8.27\left(\mathrm{~d}, 1 \mathrm{H}, J=7.3 \mathrm{~Hz}, \mathrm{H}_{\text {arom }}\right), 7.91(\mathrm{~d}, 1 \mathrm{H}$, $\left.J=8.1 \mathrm{~Hz}, \mathrm{H}_{\text {arom }}\right), 7.87\left(\mathrm{~d}, 1 \mathrm{H}, J=2.3 \mathrm{~Hz}, \mathrm{H}_{\text {arom }}\right), 7.59\left(\mathrm{t}, 1 \mathrm{H}, J=7.7 \mathrm{~Hz}, \mathrm{H}_{\text {arom }}\right), 6.95$ $\left(\mathrm{d}, 1 \mathrm{H}, J=2.3 \mathrm{~Hz}, \mathrm{H}_{\text {arom }}\right), 4.36\left(\mathrm{t}, 2 \mathrm{H}, J=7.2 \mathrm{~Hz}, \mathrm{CH}_{2}-\mathrm{N}(\mathrm{CO})_{2}\right), 4.27(\mathrm{t}, 1 \mathrm{H}, J=5.7 \mathrm{~Hz}$, $\mathrm{NH}), 3.30\left(\mathrm{dd}, 2 \mathrm{H}, J=13.8,7.2 \mathrm{~Hz}, \mathrm{CH}_{2}-\mathrm{NH}\right), 2.98\left(\mathrm{br} \mathrm{s}, 1 \mathrm{H}, \mathrm{CH}_{\text {carborane }}\right), 2.86(\mathrm{t}, 2 \mathrm{H}$, $J=7.0 \mathrm{~Hz}, \mathrm{CH}_{2}$-pyrrolidine), 2.73 (br s, $\left.4 \mathrm{H}, \mathrm{N}-\mathrm{CH}_{2 \text { pyrrolidine }}-\mathrm{CH}_{2}\right), 2.32(\mathrm{t}, 2 \mathrm{H}, J=7.5 \mathrm{~Hz}$, $\mathrm{CH}_{2}$-carborane), 1.82 (br s, $\left.4 \mathrm{H}, \mathrm{CH}_{2}-\mathrm{CH}_{2 \text { pyrrolidine }}-\mathrm{CH}_{2}\right), 3.0-1.5\left(\mathrm{~m}, 10 \mathrm{H}, \mathrm{B}_{10} \mathrm{H}_{10}\right) ;{ }^{13} \mathrm{C}$ $\operatorname{NMR}\left(\mathrm{CDCl}_{3}, 150.95 \mathrm{MHz}\right): \delta(\mathrm{ppm})=164.58(1 \mathrm{C}, \mathrm{C} 11), 164.32$ (1C, C12), 145.78-109.69 (10C, $\left.10 \mathrm{C}_{\text {arom }}\right), 73.47\left(1 \mathrm{C}, \mathrm{C}_{\text {carborane }}\right), 55.36\left(1 \mathrm{C}, \mathrm{CH}_{\text {carborane }}\right), 54.50\left(1 \mathrm{C}, \mathrm{N}-\mathrm{CH}_{2}\right.$ pyrrolidine $\left.-\mathrm{CH}_{2}\right)$, 53.87 (1C, $\mathrm{CH}_{2}$-pyrrolidine), $43.23\left(1 \mathrm{C}, \mathrm{CH}_{2}-\mathrm{NH}\right), 39.11,\left(1 \mathrm{C}, \mathrm{CH}_{2}-\mathrm{N}(\mathrm{CO})_{2}\right), 35.48\left(1 \mathrm{C}, \mathrm{CH}_{2}-\right.$ carborane), $23.79\left(1 \mathrm{C}, \mathrm{CH}_{2}-\mathrm{CH}_{2}\right.$ pyrrolidine $\left.-\mathrm{CH}_{2}\right) ;{ }^{11} \mathrm{~B}-\mathrm{NMR}\left\{{ }^{1} \mathrm{H} \mathrm{BB}\right\}\left(\mathrm{CDCl}_{3}, 192.59 \mathrm{MHz}\right): \delta$ $(\mathrm{ppm})=-4.18(\mathrm{~s}, 1 \mathrm{~B}, \mathrm{~B} 5),-9.40(\mathrm{~s}, 1 \mathrm{~B}, \mathrm{~B} 12),-10.52--10.92(\mathrm{~m}, 4 \mathrm{~B}, \mathrm{~B} 4,6,9,10),-13.41$ (s, 2B, B8, 11), -15.22 (s, 2B, B2, 3); UV (99.8\% EtOH): $\lambda_{\max }=257,341,441 \mathrm{~nm}, \lambda_{\min }=236$, $313,367 \mathrm{~nm}, \lambda_{\text {sh }}=280 \mathrm{~nm}$; FT-IR: $v_{\max }\left(\mathrm{cm}^{-1}\right)=2961\left(\mathrm{C}-\mathrm{H}_{\text {aliphat }}\right), 2593(\mathrm{~B}-\mathrm{H}), 1697(\mathrm{C}=\mathrm{O})$, $1657(\mathrm{C}=\mathrm{O}), 728$ (B-B); RP-HPLC (gradient B): $t_{\mathrm{R}}=22.95 \mathrm{~min}$; APCI-MS: $m / z: 480[\mathrm{M}+\mathrm{H}]^{+}$, calcd for $\mathrm{C}_{22} \mathrm{H}_{33} \mathrm{~B}_{10} \mathrm{~N}_{3} \mathrm{O}_{2}=479$.

3.1.7. Synthesis of Naphthalimide Derivatives 39-42 Modified with Carborane Cluster via Amidation Reaction

3-Amino-N-[2-(dimethylamino)ethyl]-1,8-naphthalimide (21) $(29.4 \mathrm{mg}, 104 \mu \mathrm{moL})$ or 3amino- $N$-[2-(N-pyrrolidinyl)ethyl]-1,8-naphthalimide (22) $(32.1 \mathrm{mg}, 104 \mu \mathrm{moL})$ and 3-(1,2dicarba-closo-dodecaboran-1-yl)propionic acid (37) $(15 \mathrm{mg}, 69.3 \mu \mathrm{moL})$ or 3-(1,7-dicarba-closododecaboran-1-yl)propionic acid (38) (15 mg, $69.3 \mu \mathrm{moL})$ were dissolved in anhydrous $\mathrm{CH}_{2} \mathrm{Cl}_{2}$ $(0.6 \mathrm{~mL})$, then anhydrous TEA $(19.3 \mu \mathrm{L}, 138.6 \mu \mathrm{moL})$ and PyBOP $(36 \mathrm{mg}, 69.3 \mu \mathrm{moL})$ were added. The reaction mixture was stirred for $2-3 \mathrm{~h}$ at RT under an inert (Ar) atmosphere. After that an additional portion of PyBOP $(18 \mathrm{mg}, 34.7 \mu \mathrm{moL})$ was added and mixture was stirred for $2-3 \mathrm{~h}$ at $\mathrm{RT}$ under an inert (Ar) atmosphere. The reaction mixture was diluted with $\mathrm{CH}_{2} \mathrm{Cl}_{2}(2 \mathrm{~mL})$ and washed witH-NaHCO $3(5 \%$ w/v, $6 \times 1.5 \mathrm{~mL})$ and water $(2 \times 1.5 \mathrm{~mL})$. The organic layer was dried over $\mathrm{MgSO}_{4}$, then the drying agent was filtered off and washed with $\mathrm{CH}_{2} \mathrm{Cl}_{2}$. Filtrate and washings were combined, and evaporated to dryness under a vacuum. The crude product was purified twice by column chromatography on silica gel (230-400 mesh) using a gradient of $\mathrm{MeOH}(3-10 \%)$ in $\mathrm{CH}_{2} \mathrm{Cl}_{2}$ as an eluting solvent system.

N-[2-(Dimethylamino)ethyl]-3-[(1,2-dicarba-closo-dodecaborane-1-yl)propanamido]-1,8-naphthalimide (39): white solid. Yield: $18 \mathrm{mg}(54 \%)$. TLC $\left(\mathrm{MeOH} / \mathrm{CH}_{2} \mathrm{Cl}_{2}, 1: 9, v / v\right): R_{\mathrm{f}}=0.31 .{ }^{1} \mathrm{H}-\mathrm{NMR}$ (acetone- $\left.\mathrm{d}_{6}, 600.26 \mathrm{MHz}\right): \delta(\mathrm{ppm})=9.85(\mathrm{~s}, 1 \mathrm{H}, \mathrm{NH}), 8.69\left(\mathrm{~d}, 1 \mathrm{H}, J=2.1 \mathrm{~Hz}, \mathrm{H}_{\text {arom }}\right)$, $8.56\left(\mathrm{~d}, 1 \mathrm{H}, J=2.1 \mathrm{~Hz}, \mathrm{H}_{\text {arom }}\right), 8.38\left(\mathrm{~d}, 1 \mathrm{H}, J=7.2 \mathrm{~Hz}, \mathrm{H}_{\text {arom }}\right), 8.24(\mathrm{~d}, 1 \mathrm{H}, J=8.3 \mathrm{~Hz}$, $\left.\mathrm{H}_{\text {arom }}\right), 7.77\left(\mathrm{t}, 1 \mathrm{H}, J=7.7 \mathrm{~Hz}, \mathrm{H}_{\text {arom }}\right), 4.75\left(\right.$ br s, $\left.1 \mathrm{H}, \mathrm{CH}_{\text {carborane }}\right), 4.24(\mathrm{t}, 2 \mathrm{H}, J=7.0 \mathrm{~Hz}$, $\left.\mathrm{CH}_{2}-\mathrm{N}(\mathrm{CO})_{2}\right), 2.84$ (br s, $4 \mathrm{H}, \mathrm{CH}_{2}-\mathrm{CONH}$ overlapped with $\mathrm{CH}_{2}$-carborane), $2.59(\mathrm{t}, \mathrm{J}=$ $\left.7.0 \mathrm{~Hz}, 2 \mathrm{H}, \mathrm{CH}_{2}-\mathrm{N}\left(\mathrm{CH}_{3}\right)_{2}\right), 2.27\left(\mathrm{~s}, 6 \mathrm{H}, \mathrm{N}\left(\mathrm{CH}_{3}\right)_{2}\right), 3.0-1.5\left(\mathrm{~m}, 10 \mathrm{H}, \mathrm{B}_{10} \mathrm{H}_{10}\right) ;{ }^{13} \mathrm{C}-\mathrm{NMR}$ 
(acetone- $\left.\mathrm{d}_{6}, 150.95 \mathrm{MHz}\right): \delta(\mathrm{ppm})=170.29\left(1 \mathrm{C}, \mathrm{C}_{\text {amide }}\right), 164.50$ (1C, C11), 164.22 (1C, C12), 138.74-121.91 (10C, 10C arom), 76.53 (1C, $\left.\mathrm{C}_{\text {carborane }}\right), 63.88$ (1C, $\left.\mathrm{CH}_{\text {carborane }}\right), 57.74$ (1C, $\left.\mathrm{CH}_{2}-\mathrm{N}\left(\mathrm{CH}_{3}\right)_{2}\right), 46.01\left(2 \mathrm{C}, 2 \times \mathrm{CH}_{3}\right), 38.81\left(1 \mathrm{C}, \mathrm{CH}_{2}-\mathrm{N}(\mathrm{CO})_{2}\right), 36.72\left(1 \mathrm{C}, \mathrm{CH}_{2}-\mathrm{CONH}\right) .33 .37$ $\left(1 \mathrm{C}, \mathrm{CH}_{2}\right.$-carborane); ${ }^{11} \mathrm{~B}-\mathrm{NMR}\left\{{ }^{1} \mathrm{H} \mathrm{BB}\right\}$ (acetone- $\left.\mathrm{d}_{6}, 192.59 \mathrm{MHz}\right): \delta(\mathrm{ppm})=-2.69(\mathrm{~s}, 1 \mathrm{~B}$, B9), -5.98 (s, 1B, B12), -9.67 (s, 2B, B8, 10), -11.55--12.92 (s, 6B, B3, 4, 5, 6, 7, 11); UV $(99.8 \% \mathrm{EtOH}): \lambda_{\max }=253,337,375 \mathrm{~nm}, \lambda_{\min }=293,357 \mathrm{~nm}, \lambda_{\mathrm{sh}}=228 \mathrm{~nm} ;$ FT-IR: $\nu_{\max }\left(\mathrm{cm}^{-1}\right)$

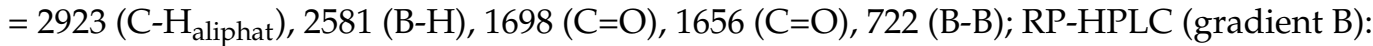
$t_{\mathrm{R}}=21.35 \mathrm{~min}$; APCI-MS: $m / z: 482[\mathrm{M}+\mathrm{H}]^{+}$, calcd for $\mathrm{C}_{21} \mathrm{H}_{31} \mathrm{~B}_{10} \mathrm{~N}_{3} \mathrm{O}_{3}=481$.

N-[2-(N-Pyrrolidinyl)ethyl]-3-[(1,2-dicarba-closo-dodecaborane-1-yl)propanamido]-1,8-naphthalimide (40): white solid. Yield: $23.2 \mathrm{mg}(66 \%)$. TLC $\left(\mathrm{MeOH} / \mathrm{CH}_{2} \mathrm{Cl}_{2}, 1: 9, v / v\right): R_{\mathrm{f}}=0.31 .{ }^{1} \mathrm{H}-\mathrm{NMR}$ $\left(\mathrm{DMSO}_{\mathrm{d}}, 600.26 \mathrm{MHz}\right): \delta(\mathrm{ppm})=10.64(\mathrm{~s}, 1 \mathrm{H}, \mathrm{NH}), 8.67\left(\mathrm{~d}, 1 \mathrm{H}, J=1.9 \mathrm{~Hz}, \mathrm{H}_{\text {arom }}\right), 8.60$ $\left(\mathrm{d}, 1 \mathrm{H}, J=1.9 \mathrm{~Hz}, \mathrm{H}_{\text {arom }}\right), 8.35-8.34\left(\mathrm{~m}, 2 \mathrm{H}, 2 \mathrm{H}_{\text {arom }}\right), 7.79\left(\mathrm{t}, 1 \mathrm{H}, J=7.7 \mathrm{~Hz}, \mathrm{H}_{\text {arom }}\right), 5.24$

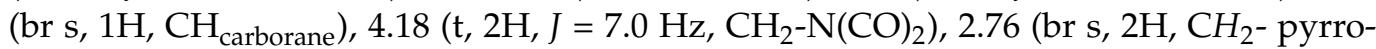
lidine), 2.71-2.67 (m, 4H, $\mathrm{CH}_{2}-\mathrm{CONH}$ overlapped with $\mathrm{CH}_{2}$-carborane), 2.62 (br s, 4H, $\left.\mathrm{N}-\mathrm{CH}_{2 \text { pyrrolidine }}-\mathrm{CH}_{2}\right), 1.69$ (br s, $\left.4 \mathrm{H}, \mathrm{CH}_{2}-\mathrm{CH}_{2 \text { pyrrolidine }}-\mathrm{CH}_{2}\right), 3.0-1.5\left(\mathrm{~m}, 10 \mathrm{H}, \mathrm{B}_{10} \mathrm{H}_{10}\right)$; ${ }^{13} \mathrm{C}-\mathrm{NMR}\left(\mathrm{DMSO}_{\mathrm{d}}, 150.95 \mathrm{MHz}\right): \delta(\mathrm{ppm})=169.32\left(1 \mathrm{C}, \mathrm{C}_{\text {amide }}\right), 163.32\left(1 \mathrm{C}, \mathrm{C}_{\text {imide }}\right), 163.10$ (1C, $\left.\mathrm{C}_{\text {imide }}\right), 137.65-120.79$ (10C, 10C arom), 75.66 (1C, $\left.\mathrm{C}_{\text {carborane }}\right), 63.47$ (1C, $\left.\mathrm{CH}_{\text {carborane }}\right)$, 53.69 (1C, N-CH $\mathrm{CH}_{2}$ pyrolidine $\left.-\mathrm{CH}_{2}\right), 52.85$ (1C, $\mathrm{CH}_{2}$-pyrrolidine), $38.42\left(1 \mathrm{C}, \mathrm{CH}_{2}-\mathrm{N}(\mathrm{CO})_{2}\right)$, 35.59 (1C, $\left.\mathrm{CH}_{2}-\mathrm{CONH}\right) .31 .88$ (1C, $\mathrm{CH}_{2}$-carborane), 23.11 (1C, $\mathrm{CH}_{2}-\mathrm{CH}_{2 \text { pyrrolidine }}-\mathrm{CH}_{2}$ ); ${ }^{11} \mathrm{~B}-\mathrm{NMR}\left\{{ }^{1} \mathrm{H} \mathrm{BB}\right\}\left(\mathrm{DMSO}_{6}, 192.59 \mathrm{MHz}\right): \delta(\mathrm{ppm})=-3.10(\mathrm{~s}, 1 \mathrm{~B}, \mathrm{~B} 9),-6.05$ (s, 1B, B12), -9.75 (s, 2B, B8, 10), -11.69--12.92 (m, 6B, B3, 4, 5, 6, 7, 11); UV (99.8\% EtOH): $\lambda_{\max }=254$, $338,375 \mathrm{~nm}, \lambda_{\min }=293,357 \mathrm{~nm}, \lambda_{\mathrm{sh}}=228 \mathrm{~nm}$; FT-IR: $\nu_{\max }\left(\mathrm{cm}^{-1}\right)=2922\left(\mathrm{C}^{-\mathrm{H}_{\text {aliphat }}}\right), 2576$ (B-H), $1704(\mathrm{C}=\mathrm{O}), 1661(\mathrm{C}=\mathrm{O}), 722(\mathrm{~B}-\mathrm{B})$; RP-HPLC (gradient B): $t_{\mathrm{R}}=21.39 \mathrm{~min}$; APCI-MS: $m / z: 508[\mathrm{M}+\mathrm{H}]^{+}$, calcd for $\mathrm{C}_{23} \mathrm{H}_{33} \mathrm{~B}_{10} \mathrm{~N}_{3} \mathrm{O}_{3}=507$; HRMS (ESI+) $508.3761[\mathrm{M}+\mathrm{H}]^{+}$, calcd for $\mathrm{C}_{23} \mathrm{H}_{33} \mathrm{~B}_{10} \mathrm{~N}_{3} \mathrm{O}_{3}=508.3598[\mathrm{M}+\mathrm{H}]^{+}$.

N-[2-(Dimethylamino)ethyl]-3-[(1,7-dicarba-closo-dodecaborane-1-yl)propanamido]-1,8naphthalimide (41): white solid. Yield: $18.2 \mathrm{mg}$, (55\%). TLC (MeOH/ $\left.\mathrm{CH}_{2} \mathrm{Cl}_{2}, 1: 9, v / v\right)$ : $R_{\mathrm{f}}=0.34 .{ }^{1} \mathrm{H}-\mathrm{NMR}$ (acetone- $\left.\mathrm{d}_{6}, 600.26 \mathrm{MHz}\right): \delta(\mathrm{ppm})=9.72(\mathrm{~s}, 1 \mathrm{H}, \mathrm{NH}), 8.73(\mathrm{~d}, 1 \mathrm{H}$, $\left.J=2.1 \mathrm{~Hz}, \mathrm{H}_{\text {arom }}\right), 8.55\left(\mathrm{~d}, 1 \mathrm{H}, J=2.1 \mathrm{~Hz}, \mathrm{H}_{\text {arom }}\right), 8.39\left(\mathrm{dd}, 1 \mathrm{H}, J=7.2,1.0 \mathrm{~Hz}, \mathrm{H}_{\text {arom }}\right)$, $8.26\left(\mathrm{~d}, 1 \mathrm{H}, J=8.3 \mathrm{~Hz}, \mathrm{H}_{\text {arom }}\right), 7.79\left(\mathrm{dd}, 1 \mathrm{H}, J=8.1,7.3 \mathrm{~Hz}, \mathrm{H}_{\text {arom }}\right), 4.25(\mathrm{t}, 2 \mathrm{H}, J=6.9 \mathrm{~Hz}$,

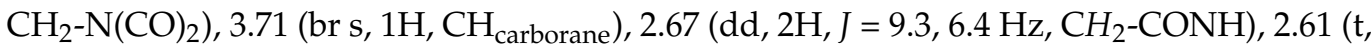
$\left.2 \mathrm{H}, \mathrm{J}=7.0 \mathrm{~Hz}, \mathrm{CH}_{2}-\mathrm{N}\left(\mathrm{CH}_{3}\right)_{2}\right), 2.54\left(\mathrm{dd}, 2 \mathrm{H}, \mathrm{J}=9.3,6.7 \mathrm{~Hz}, \mathrm{CH}_{2}\right.$-carborane), $2.30(\mathrm{~s}, 6 \mathrm{H}$, $\left.\mathrm{N}\left(\mathrm{CH}_{3}\right)_{2}\right), 3.0-1.5\left(\mathrm{~m}, 10 \mathrm{H}, \mathrm{B}_{10} \mathrm{H}_{10}\right) ;{ }^{13} \mathrm{C}-\mathrm{NMR}\left(\right.$ acetone-d $\left.\mathrm{d}_{6}, 150.95 \mathrm{MHz}\right): \delta(\mathrm{ppm})=170.34$ (1C, $\left.C_{\text {amide }}\right), 164.46$ (1C, $\left.C_{\text {imide }}\right), 164.18$ (1C, $\left.C_{\text {imide }}\right), 138.85-121.73$ (10C, 10C arom ), 76.72 (1C, $\left.\mathrm{C}_{\text {carborane }}\right), 57.74\left(1 \mathrm{C}, \mathrm{CH}_{2}-\mathrm{N}\left(\mathrm{CH}_{3}\right)_{2}\right), 56.92\left(1 \mathrm{C}, \mathrm{CH}_{\text {carborane }}\right), 46.03\left(2 \mathrm{C}, 2 \times \mathrm{CH}_{3}\right), 38.79$ $\left(1 \mathrm{C}, \mathrm{CH}_{2}-\mathrm{N}(\mathrm{CO})_{2}\right), 37.14\left(1 \mathrm{C}, \mathrm{CH}_{2}-\mathrm{CONH}\right), 32.49$ (1C, $\mathrm{CH}_{2}$-carborane); ${ }^{11} \mathrm{~B}-\mathrm{NMR}\left\{{ }^{1} \mathrm{H} \mathrm{BB}\right\}$ (acetone- $\left.\mathrm{d}_{6}, 192.59 \mathrm{MHz}\right): \delta(\mathrm{ppm})=-4.33(\mathrm{~s}, 1 \mathrm{~B}, \mathrm{~B} 5),-9.87--10.92(\mathrm{~m}, 5 \mathrm{~B}, \mathrm{~B} 4,6,9,10$, 12), -13.45 (s, 2B, B8, 11), -14.93 (s, 2B, B2, 3); UV (99.8\% EtOH): $\lambda_{\max }=258,338,375 \mathrm{~nm}$, $\lambda_{\min }=293,358 \mathrm{~nm}, \lambda_{\mathrm{sh}}=228 \mathrm{~nm}$; FT-IR: $v_{\max }\left(\mathrm{cm}^{-1}\right)=2922\left(\mathrm{C}-\mathrm{H}_{\text {aliphat }}\right), 2597(\mathrm{~B}-\mathrm{H}), 1697$ $(\mathrm{C}=\mathrm{O}), 1657(\mathrm{C}=\mathrm{O}), 730$ (B-B); RP-HPLC (gradient B): $t_{\mathrm{R}}=21.03 \mathrm{~min}$; APCI-MS: $\mathrm{m} / z: 482$ $[\mathrm{M}+\mathrm{H}]^{+}$, calcd for $\mathrm{C}_{21} \mathrm{H}_{31} \mathrm{~B}_{10} \mathrm{~N}_{3} \mathrm{O}_{3}=481$.

N-[2-(N-Pyrrolidinyl)ethyl]-3-[(1,7-dicarba-closo-dodecaborane-1-yl)propanamido]-1,8naphthalimide (42): white solid. Yield: $17.2 \mathrm{mg}(49 \%)$. TLC $\left(\mathrm{MeOH} / \mathrm{CH}_{2} \mathrm{Cl}_{2}, 1: 9, v / v\right)$ : $R_{\mathrm{f}}=0.34 .{ }^{1} \mathrm{H}-\mathrm{NMR}\left(\mathrm{DMSO}-\mathrm{d}_{6}, 600.26 \mathrm{MHz}\right): \delta(\mathrm{ppm})=10.59(\mathrm{~s}, 1 \mathrm{H}, \mathrm{NH}), 8.69(\mathrm{~d}, 1 \mathrm{H}$, $\left.J=1.9 \mathrm{~Hz}, \mathrm{H}_{\text {arom }}\right), 8.58\left(\mathrm{~d}, 1 \mathrm{H}, J=2.1 \mathrm{~Hz}, \mathrm{H}_{\text {arom }}\right), 8.35-8.33\left(\mathrm{~m}, 2 \mathrm{H}, 2 \mathrm{H}_{\text {arom }}\right), 7.79(\mathrm{t}, 1 \mathrm{H}$, $\left.J=7.7 \mathrm{~Hz}, \mathrm{H}_{\text {arom }}\right), 4.18$ (t, 2H, $\left.J=7.1 \mathrm{~Hz}, \mathrm{CH}_{2}-\mathrm{N}(\mathrm{CO})_{2}\right), 4.09$ (br s, 1H, $\left.\mathrm{CH}_{\text {carborane }}\right), 2.72$ (br s, 2H, CH -pyrrolidine), 2.59 (br s, $4 \mathrm{H}, \mathrm{N}-\mathrm{CH}_{2 \text { pyrrolidine }}-\mathrm{CH}_{2}$ ), $2.54\left(\mathrm{t}, 2 \mathrm{H}, \mathrm{J}=8.6 \mathrm{~Hz}, \mathrm{CH}_{2}\right.$ $\mathrm{CONH}), 2.40\left(\mathrm{t}, 2 \mathrm{H}, J=8.0 \mathrm{~Hz}, \mathrm{CH}_{2}\right.$-carborane), 1.69 (br s, $4 \mathrm{H}, \mathrm{CH}_{2}-\mathrm{CH}_{2 \text { pyrrolidine }}-\mathrm{CH}_{2}$ ), 3.0-1.5 (m, 10H, $\left.\mathrm{B}_{10} \mathrm{H}_{10}\right)$; ${ }^{13} \mathrm{C}-\mathrm{NMR}\left(\mathrm{DMSO}_{6}, 150.95 \mathrm{MHz}\right): \delta(\mathrm{ppm})=169.58\left(1 \mathrm{C}, \mathrm{C}_{\text {amide }}\right)$, 163.31 (1C, $\left.C_{\text {imide }}\right), 163.08$ (1C, C imide), 137.74-120.69 (10C, 10C arom), 75.84 (1C, $\left.C_{\text {carborane }}\right)$,

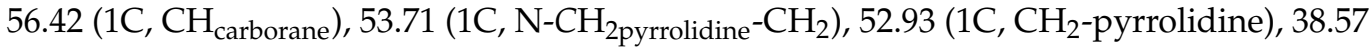
$\left(1 \mathrm{C}, \mathrm{CH}_{2}-\mathrm{N}(\mathrm{CO})_{2}\right), 36.16\left(1 \mathrm{C}, \mathrm{CH}_{2}-\mathrm{CONH}\right), 31.14$ (1C, $\mathrm{CH}_{2}$-carborane), $23.16\left(1 \mathrm{C}, \mathrm{CH}_{2}-\right.$ $\left.\mathrm{CH}_{2 \text { pyrrolidine }}-\mathrm{CH}_{2}\right) ;{ }^{11} \mathrm{~B}-\mathrm{NMR}\left\{{ }^{1} \mathrm{H} \mathrm{BB}\right\}\left(\mathrm{DMSO} \mathrm{d}_{6}, 192.59 \mathrm{MHz}\right): \delta(\mathrm{ppm})=-4.58(\mathrm{~s}, 1 \mathrm{~B}$, B5), -11.09 (m, 5B, B4, 6, 9, 10, 12), -13.55 (s, 2B, B8, 11), -14.94 (s, 2B, B2, 3); UV (99.8\% 
$\mathrm{EtOH}): \lambda_{\max }=254,338,375 \mathrm{~nm}, \lambda_{\min }=293,358 \mathrm{~nm}, \lambda_{\mathrm{sh}}=229 \mathrm{~nm}$; FT-IR: $v_{\max }\left(\mathrm{cm}^{-1}\right)=$ 2921 (C-H aliphat $_{\text {), }} 2597$ (B-H), 1696 (C=O), 1654 (C=O), 728 (B-B); RP-HPLC (gradient B): $t_{\mathrm{R}}=21.27 \mathrm{~min}$; APCI-MS: $m / z: 508[\mathrm{M}+\mathrm{H}]^{+}$, calcd for $\mathrm{C}_{23} \mathrm{H}_{33} \mathrm{~B}_{10} \mathrm{~N}_{3} \mathrm{O}_{3}=507$.

\subsection{Biological Investigation}

\subsubsection{Cytotoxicity Assay}

The cytotoxic properties of synthesized compounds were evaluated using human cancer cell line HepG2 established from hepatocellular carcinoma. Cell lines was purchased from Leibniz Institute DSMZ-German Collection of Microorganisms and Cell Cultures (DSMZ, Braunschweig, Germany) and from ECACC (Salisbury, UK).

HepG2 cells were propagated in Dulbecco's Modified Eagle Medium (DMEM, Braunschweig, Germany; Life Technologies, Warsaw, Poland) supplemented with 10\% heatinactivated fetal bovine serum (FBS; Life Technologies, Warsaw, Poland) and 100 units/mL penicillin G with $100 \mathrm{mg} / \mathrm{mL}$ streptomycin (Life Technologies, Warsaw, Poland). The cells were incubated at $37^{\circ} \mathrm{C}$ in a humidified atmosphere containing $5 \% \mathrm{CO}_{2}$.

Upon reaching 80-90\% confluency, cells were harvested with $0.25 \%$ trypsin in $1 \mathrm{mM}$ EDTA (Life Technologies, Warsaw, Poland) and transferred into 96-well microplates at 5000 cells / well (HepG2 cells). After overnight incubation of cells at $37^{\circ} \mathrm{C}$ in a humidified atmosphere containing $5 \% \mathrm{CO}_{2}$, the culture medium was removed and replaced with a freshly prepared solution of compounds in culture medium or medium itself as the control group.

Stock solution of each compound was prepared in DMSO at $50 \mathrm{mM}$. Stock solutions were diluted with the growth medium supplemented with 5\% FBS to ensure drug dissolution for obtaining concentrations ranging from 0.1 to $200 \mu \mathrm{M}$. The cytotoxicity was evaluated by the MTT assay. The final content of DMSO in solutions did not exceed $0.2 \%$, and an additional control group with $0.2 \%$ DMSO was included to rule out the effect of solvent. After treatment, cells were incubated at $37^{\circ} \mathrm{C}$ in $5 \% \mathrm{CO}_{2}$ for additional $24 \mathrm{~h}$. Upon completion of the incubation, the medium was aspirated and replaced with 3-(4,5-dimethylthiazol-2-yl)-2,5-diphenyltetrazolium bromide (MTT) dye solution (50 $\mu \mathrm{L}$, $0.5 \mathrm{mg} / \mathrm{mL}$ ). After $3 \mathrm{~h}$ incubation, the resulting MTT formazan crystals were dissolved in DMSO $(100 \mu \mathrm{L})$. To ensure the complete dissolution of formazan, the plates were shaken on an orbital microplate shaker at $1000 \mathrm{rpm}$ for $15 \mathrm{~min}$ (Thermoshaker NeoLab 7-0055, Bionovo, Legnica, Poland). The optical density of each well was then measured on a microplate spectrophotometer (Bio-Rad 680; Bio-Rad, Warsaw, Poland) at a wavelength of $570 \mathrm{~nm}$. Each experiment consisted of 5 replications of each concentration, and each experiment was repeated three times independently. The results were calculated as percentage of control group viability. The $\mathrm{IC}_{50}$ values were determined using a nonlinear regression from the plot of \% viability against log dose of compounds by using GraphPad Prism 6.0 software (GraphPad, San Diego, CA, USA).

\subsubsection{Cell Cycle Analysis by Flow Cytometry}

HepG2 $\left(5 \times 10^{5}\right)$ cells were seeded onto 6-well cell culture plates and incubated for $24 \mathrm{~h}$ with the analyzed compounds at a concentration corresponding to whole $\mathrm{IC}_{50}$ values. DNA content was determined by flow cytometry with PI (Sigma-Aldrich (Steinheim, Germany)) staining. After incubation, the cells were trypsinized and washed twice with PBS (1 mL). In the next step, the cells were fixed with an ice-cold $80 \%$ ethanol. After $1 \mathrm{~h}$ incubation in $4{ }^{\circ} \mathrm{C}$, the cells were stored at $-20{ }^{\circ} \mathrm{C}$ for further analysis. After double wash with PBS, the fixed cells were stained with PI $(50 \mu \mathrm{g} / \mathrm{mL})$ with the addition of RNAse A $(100 \mu \mathrm{g} / \mathrm{mL})$ for $30 \mathrm{~min}$ at $37^{\circ} \mathrm{C}$ in the dark. The PI fluorescence was measured by FACSCalibur (Becton Dickinson, Franklin Lake, NJ, USA), and data were analyzed by FlowJo software.

\subsubsection{Oxidative Stress Measurements in HepG2 Cells by Flow Cytometry}

HepG2 cells $\left(3.5 \times 10^{5}\right)$ were seeded onto 6-well plates, cultured with EMEM media at $37^{\circ} \mathrm{C}$ and $5 \% \mathrm{CO}_{2}$ saturation, and incubated until $60-70 \%$ confluence. Subsequently, the 
cells were treated for $24 \mathrm{~h}$ with the tested compounds at a concentration that corresponds to a half of $\mathrm{IC}_{50}$ value. Next, the cells were detached with trypsin (Sigma-Aldrich (Steinheim, Germany)) and washed twice with DPBS $(1 \mathrm{~mL})$ (Thermo Fisher Scientific (Waltham, MA, USA)), and the level of intracellular ROS generation was analyzed by dual staining with $\mathrm{H}_{2}$ DCFDA/PI according to the manufacturer's protocol (Thermo Fisher Scientific (Waltham, MA, USA)), in which fluorescence was triggered in the presence of ROS.

\subsubsection{Analysis of 8-Oxo-dG in HepG2 Cells by HPLC-UV-ED}

HepG2 cells $\left(1 \times 10^{6}\right)$ were seeded onto flasks $\left(25 \mathrm{~cm}^{2}\right)$ and cultured in the supplemented growth medium for $16 \mathrm{~h}$. Subsequently, the cells were treated with compounds $31(53 \mu \mathrm{M}), 33(5 \mu \mathrm{M}), 34(8 \mu \mathrm{M}), 35(9 \mu \mathrm{M})$, and $36(6 \mu \mathrm{M})$ for $24 \mathrm{~h}$. After incubation, the cells were trypsinized, rinsed twice with PBS, and pelleted by centrifugation $(200 \times g$, $3 \mathrm{~min}$ ). Total DNA was isolated from the treated cells and untreated control cells by using Genomic mini DNA isolation kit (A \& A Biotechnology, Gdynia, Poland) according to the manufacturer's protocol. Quality of the total DNA was assessed spectrophotometrically.

DNA $(1 \mu \mathrm{g})$ was dissolved in sodium acetate buffer $(10 \mu \mathrm{L}, 40 \mathrm{mM}, \mathrm{pH}$ 5.3) containing $\mathrm{ZnCl}_{2}(0.1 \mathrm{mM})$ and digested witH-Nuclease $P 1(3 \mu \mathrm{g})$. Samples were incubated for $3 \mathrm{~h}$ at $37^{\circ} \mathrm{C}$. Subsequently, Tris- $\mathrm{HCl}(2 \mu \mathrm{L}, 1 \mathrm{M}, \mathrm{pH} 8.0)$ and alkaline phosphatase $(1 \mathrm{U})$ were added and incubated $2 \mathrm{~h}$ at $37^{\circ} \mathrm{C}$. All DNA hydrolysates were ultrafiltered using cut off 10,000 Da filter units.

8-Oxo-dG, and dG in hydrolysates were determined using HPLC-UV followed by electrochemical detection and ED (Coulochem III Electrochemical Detector, ESA, Inc., Chelmsford, MA, USA). DNA hydrolysates were chromatographed isocratically by using ammonium acetate (50 mM pH 5.3)/methanol (93:7, v/v). Detection of dG was performed at $254 \mathrm{~nm}$. 8-Oxo-dG was performed by the electrochemical detector: guard cell $+400 \mathrm{mV}$, detector 1: $+130 \mathrm{mV}$ (as a screening electrode), detector 2: $+350 \mathrm{mV}$ (as a measuring electrode set to sensitivity of $500 \mathrm{nA} / \mathrm{V}$ ). All results are expressed as mean $\pm \mathrm{SD}$.

To determine 8-oxo-dG contents guanosine amount was necessary. The total number of 8-oxo-dG in genome was calculated using special formula [80].

\subsubsection{Apoptosis/Necrosis Assay by Flow Cytometry}

Apoptosis/necrosis assay was performed by double staining of cells with YO-PRO-1 (Thermo Fisher Scientific (Waltham, MA, USA)) and propidium iodide (PI, Sigma-Aldrich (Steinheim, Germany)) fluorescent dyes. Briefly, HepG2 cells $\left(0.5 \times 10^{5}\right)$ were seeded onto 6-well plates. On the next day, the cells were treated for $24 \mathrm{~h}$ with the analyzed compounds at a concentration corresponding to whole $\mathrm{IC}_{50}$ values. Subsequently, the cells were detached with trypsin (Thermo Fisher Scientific (Waltham, MA, USA)), washed twice with DPBS (1 mL) (Thermo Fisher Scientific (Waltham, MA, USA)), and stained with YO-PRO-1 and PI according to the manufacturer's protocol for $30 \mathrm{~min}$ at $37^{\circ} \mathrm{C}$ in the dark. The cells were analyzed immediately after staining with $488 \mathrm{~nm}$ excitation by Accuri C6 flow cytometer (Becton Dickinson, Franklin Lake, NJ, USA).

\subsubsection{Apoptosis Detection Using Annexin V Conjugate Staining}

HepG2 cells $\left(4 \times 10^{5}\right)$ were seeded onto 6-well plates, cultured with EMEM media at $37{ }^{\circ} \mathrm{C}$ and $5 \% \mathrm{CO}_{2}$, and incubated until $60-70 \%$ confluence. Subsequently, the cells were treated for $24 \mathrm{~h}$ with the tested compounds 31, 33-36 were added at concentration that corresponds to the whole $\mathrm{IC}_{50}$ value. After $24 \mathrm{~h}$ incubation, the cells were washed with ice-cold PBS buffer (Gibco, Grand Island, NJ, USA), harvest with $1 \times$ trypsin/EDTA (Corning), and centrifuged (1200 rpm, $3 \mathrm{~min}$ ). Next, the cells were washed in ice-cold PBS and recentrifuged. Supernatants were discarded, and the cells were suspended in annexinbinding buffer $\left(100 \mu \mathrm{L}, 10 \mathrm{mM}\right.$ HEPES, $140 \mathrm{mM} \mathrm{NaCl}$, and $2.5 \mathrm{mM} \mathrm{CaCl}_{2}, \mathrm{pH}$ 7.4). The cells were stained by adding of the Annexin V Alexa Fluor 647 conjugate $(5 \mu \mathrm{L})$ (Thermo Fisher (Waltham, MA, USA)). The cells were incubated at RT, for 15 min, in the dark. After incubation, annexin binding buffer $(400 \mu \mathrm{L})$ was added to the Alexa Fluor 647-stained 
cells, mixed gently, and kept on ice until analysis. The rate of apoptosis was evaluated immediately after incubation by FACSCalibur flow cytometer with excitation at $635 \mathrm{~nm}$.

\subsubsection{Autophagy Assay by Flow Cytometry}

Autophagy assay was performed in HepG2 cells by staining with Green Detection Reagent (Autophagy Detection Kit, ab139484, Abcam, Cambridge, UK) fluorescent dye with excitation/emission at $463 / 534 \mathrm{~nm}$. Briefly, the cells $\left(3.85 \times 10^{5}\right)$ were seeded onto 6-well plates containing the growth medium (EMEM) and incubated until 70-80\% confluency. On the next day, the cells were treated for $24 \mathrm{~h}$ with the analyzed compounds at a concentration corresponding to whole $\mathrm{IC}_{50}$ values. Rapamycin (autophagy inducer) $(1 \mu \mathrm{M})$ was used to create a strong, single positive green fluorescence signal. Subsequently, the cells were detached with trypsin (Thermo Fisher Scientific (Waltham, MA, USA)), washed twice with DPBS (1 mL) (Thermo Fisher Scientific (Waltham, MA, USA)), and stained with Green Detection Reagent according to the manufacturer's protocol for $30 \mathrm{~min}$ at $37^{\circ} \mathrm{C}$ in the dark. The cells were analyzed immediately after staining with $488 \mathrm{~nm}$ excitation by Accuri C6 flow cytometer (Becton Dickinson, Franklin Lake, NJ, USA).

\subsubsection{Lipid Peroxidation Measurements by Flow Cytometry}

HepG2 cells $\left(3.85 \times 10^{5}\right)$ were seeded onto 6-well plates, cultured with EMEM media, at $37^{\circ} \mathrm{C}$ and $5 \% \mathrm{CO}_{2}$ saturation, and incubated until $60-70 \%$ confluence. Subsequently, the cells were treated for $24 \mathrm{~h}$ with the tested compounds at a concentration that corresponds to whole $\mathrm{IC}_{50}$ values. Next, the cells were detached with trypsin (Sigma-Aldrich (Steinheim, Germany)), washed twice with DPBS (1 mL) (Thermo Fisher Scientific (Waltham, MA, USA)) and intracellular oxidation of lipids was analyzed by staining with BODIPY ${ }^{\circledR} 581 / 591$ C11 reagent according to the manufacturer's protocol (Thermo Fisher Scientific (Waltham, MA, USA)). Upon oxidation in live cells, the reagent shifts fluorescence emission peak from $590 \mathrm{~nm}$ (red) to $510 \mathrm{~nm}$ (green). Cumene peroxide $(10 \mu \mathrm{M})$ was used as a positive control to induce lipid peroxidation. Cells were analyzed immediately after staining, with $488 \mathrm{~nm}$ excitation by FACSCalibur flow cytometer (Becton Dickinson, Franklin Lake, NJ, USA) and data were analyzed by FlowJo software. The ratios of the signal from the 590 to 510 channels were used to quantify lipid peroxidation in cells.

\subsubsection{Fluorescence Imaging Experiment}

HepG2 wells were seeded on a glass-bottom 4-well CELLview cell culture dishes (Greiner Bio-One GmbH, Kremsmünster, Austria) at a density of $10 \times 10^{4} /$ well and cultured in supplemented EMEM until 80-90\% confluency. Then cells were treated with tested compounds at the final concentration corresponding to the whole $\mathrm{IC}_{50}$ value, for $1 \mathrm{~h}$ and $24 \mathrm{~h}$. In the next step, lysosomes were labeled with $100 \mathrm{nM}$ of LysoTracker Red DND-99 (Thermo Fisher Scientific (Waltham, MA, USA)) for $15 \mathrm{~min}$, and nuclei were stained with $3 \mu \mathrm{g} / \mathrm{mL}$ of Hoechst 33342 (Thermo Fisher Scientific (Waltham, MA, USA)) for $5 \mathrm{~min}$. After incubation, the cells were gently rinsed in PBS to remove free dyes, placed in the FluoroBrite DMEM (Thermo Fisher Scientific (Waltham, MA, USA)). Live cell imaging was performed using a Leica TCS SP5 II confocal laser scanning microscope equipped with a White Light Laser (470-670 nm), a 405 laser and an environmental cell culture chamber that provided controlled conditions of temperature, $\mathrm{CO}_{2}$ saturation and humidity. Fluorescence images were collected using a Plan Apo 63x 1.4 NA oil-immersion objective at Ex/Em 488/500-600 $\mathrm{nm}$ for autofluorescence of tested compounds, 561/585-655 nm for lysosomes labeling and 405/430-480 nm for nuclei staining. LAS AF (Leica, Wetzlar, Germany) and Leica LAS X software with a deconvolution module were used for image processing and fluorescence analysis, respectively.

\subsubsection{Human Topoisomerase II $\alpha$ Relaxation Assay}

The Human Topoisomerase II-alpha Relaxation Assay Kit was purchased from Inspiralis (Norwich, UK). The Topo II-alpha inhibition assay was performed as described 
be the manufacturer. Briefly, the reaction mixture $(30 \mu \mathrm{L})$ containing tested compound $(100 \mu \mathrm{M})$ dissolved in DMSO (which final concentration of $2 \%$ or $4 \%$ had no influence on the Topo II-alpha activity), supercoiled pBR322 $(0.5 \mu \mathrm{g})$ in 1 X Assay Buffer and ATP $(1 \mathrm{mM})$ was incubated at $37^{\circ} \mathrm{C}$ for $15 \mathrm{~min}$. Next, Topo-II alpha (1 U) was added and the reaction mixture was incubated at $37^{\circ} \mathrm{C}$ for an additional $45 \mathrm{~min}$. The reaction was terminated by addition of the STEB buffer $(40 \%(w / v)$ sucrose, Tris-HCl (100 mM, pH 8$)$, EDTA (1 mM), bromophenol blue $(0.5 \mathrm{mg} / \mathrm{mL}))$. The products were analyzed by electrophoresis using agarose gel (1\%) in TEA buffer at $70 \mathrm{~V}$ for $2 \mathrm{~h}$, followed by the ethidium bromide staining For the most active compounds $\mathbf{6}$ and 7 the reaction was repeated in a concentration range of 25-200 $\mu \mathrm{M}$. The percentage of Topo-II alpha activity inhibition was calculated by densitometric quantification (Quantity One software, Bio-Rad, Warsaw, Poland). The occurrence of a band representing supercoiled DNA on an agarose gel indicated the inhibition of enzyme activity.

\subsubsection{Statistical Analysis}

Statistical analyzes were performed using GraphPad Prism version 6.0 for Windows, (GraphPad Software, San Diego, CA, USA). Apoptosis and necrosis as well as cell cycle assay was analyzed by two-way analysis of variance (ANOVA), followed by Tukey's multiple comparison test. ROS induction was analyzed by one-way ANOVA followed by Tukey's multiple comparison test. Statistical significance for mitochondrial ROS production was determined by one-way ANOVA followed by Dunnett's multiple comparison test. The results are presented as mean \pm SEM from three independent experiments; $p$ values less than 0.05 were considered statistically significant. Statistical significance is indicated with asterisks: $(n s) p>0.05,\left({ }^{*}\right) p<0.05,\left({ }^{*}\right) p<0.01,\left({ }^{* *}\right) p<0.001$, and $\left({ }^{* * *}\right) p<0.0001$.

\subsection{Physicochemical Investigation with DNA}

\subsubsection{Materials}

Calf-thymus (ct-DNA) was purchased from Sigma (St. Louis, MO, USA) and used without purification. Sodium cacodylate (for the preparation of cacodylate buffer) was purchased from Acros Organics (Geel, Belgium). Water was obtained from a Milli-Q purification system. All experiments were performed with freshly prepared solutions.

\subsubsection{Preparation of ct-DNA}

The ct-DNA was dissolved in $\mathrm{H}_{2} \mathrm{O}$, reconstituted overnight at $4{ }^{\circ} \mathrm{C}$ to dissolve all the material, and then filtered through a $0.45-\mu \mathrm{m}$ filter. The molar concentration of ctDNA was determined from UV-visible spectra by using molar absorption coefficient $(\varepsilon)$ of $6600 \mathrm{M}^{-1} \mathrm{~cm}^{-1}$ at $260 \mathrm{~nm}$ [81]. The purity of ct-DNA was confirmed by UV-visible spectroscopy by measuring the ratio of absorbance at $260 \mathrm{~nm}$ to $280 \mathrm{~nm}$ and was found to be $\geq 1.8$, indicating that DNA was sufficiently free of proteins.

\subsubsection{Melting Temperature $\left(T_{\mathrm{m}}\right)$ Measurements}

The measurements were performed by adding aliquots of acetone stock solution of the tested compounds to the buffer solution ( $\mathrm{pH} 7.0,20 \mathrm{mM}$, cacodylate buffer, acetone content of the final solution $=0.23-0.35 \%$ ). The $T_{\mathrm{m}}$ curves were collected at $\mathrm{r}=0.3$ ( $\mathrm{r}=$ [compound] $/$ [ct-DNA]) to assure the dominant binding mode. Thermal melting curves were determined by following the absorption change at $260 \mathrm{~nm}$ as a function of temperature by using a GBC Cintra10 UV-VIS spectrometer equipped with a GBC Thermocell Peltier Power Supply using a $1 \mathrm{~cm}$ path length cell. The absorbance of the samples was monitored at $260 \mathrm{~nm}$ from $30{ }^{\circ} \mathrm{C}$ to $90{ }^{\circ} \mathrm{C}$ with a heating rate of $1{ }^{\circ} \mathrm{C} / \mathrm{min}$. $T_{\mathrm{m}}$ values are the midpoints or the transition curves determined from the maximum of the first derivative. The $\Delta T_{\mathrm{m}}$ values were calculated by subtracting $T_{\mathrm{m}}$ of the free nucleic acid from $T_{\mathrm{m}}$ of the sample. Every $\Delta T_{\mathrm{m}}$ value reported in the study was the average of at least three measurements. The error in $\Delta T_{\mathrm{m}}$ was $\pm 0.5^{\circ} \mathrm{C}$. 


\subsubsection{Circular Dichroism Measurements}

The measurements were performed by adding aliquots of DMSO stock solution of the tested compounds to the buffer solution ( $\mathrm{pH} 7.0,20 \mathrm{mM}$, cacodylate buffer, DMSO content of the final solutions $=0.38-0.58 \%$ ). Changes in the CD spectrum of ct-DNA upon the addition of compound were measured at different molar ratios $r=$ [compound]/[ct-DNA] Circular dichroism spectra were recorded on a JASCO J-815 CD spectrometer with a JASCO CDF-426S Peltier thermostated cell holder (JASCO, Tokyo, Japan) by using a rectangular quartz cuvette of path length $0.5 \mathrm{~cm}(1 \mathrm{~mL})$ in the $230-400 \mathrm{~nm}$ region. The reported CD profiles are an average of three successive scans with $200 \mathrm{~nm}$ per minute scan time and an appropriately corrected baseline. The temperature was maintained at $20^{\circ} \mathrm{C}$ during the experiment.

\subsubsection{Ultraviolet-Visible Spectra Titration}

The measurements were performed by adding aliquots of acetone stock solution of the tested compounds to the buffer solution ( $\mathrm{pH} 7.4,20 \mathrm{mM}, 50 \mathrm{mM} \mathrm{NaCl}$, Tris- $\mathrm{HCl}$ buffer, acetone content of the final solutions $=0.15-1.15 \%$ ) to the final concentration $10 \mu \mathrm{M}$. The tested compounds were incubated $5 \mathrm{~min}$, with increasing concentrations ranging from 0 to $15 \mu \mathrm{M}$ of ct-DNA at $37^{\circ}$, then the UV-vis absorption spectra, between $315-455 \mathrm{~nm}$, were recorded using a GBC Cintra10 UV-VIS spectrometer equipped with a GBC Thermocell Peltier Power Supply using a $1 \mathrm{~cm}$ path length cell. The binding constant was calculated according to the following equation [82]:

$$
\frac{A_{0}}{A-A_{0}}=\frac{\varepsilon_{\mathrm{G}}}{\varepsilon_{\mathrm{H}-\mathrm{G}}-\varepsilon_{\mathrm{G}}}+\frac{\varepsilon_{\mathrm{G}}}{\varepsilon_{\mathrm{H}-\mathrm{G}}-\varepsilon_{\mathrm{G}}} \times \frac{1}{\mathrm{~K}_{b}[\mathrm{DNA}]}
$$

where $\mathrm{K}_{b}$ is the binding constant, $A_{0}$ and a are absorbance of the free tested compound and the apparent one, $\varepsilon_{\mathrm{G}}$ and $\varepsilon_{\mathrm{H}-\mathrm{G}}$ are their coefficient respectively, [DNA] is the concentration of [DNA] in base pair. The slope to intercept ratio of the plot between $A_{0} / A-A_{0}$ versus $1 /[\mathrm{DNA}]$ yielded the binding constant.

\subsection{Theoretical Calculations}

\subsubsection{Model Building and CoMFA Modeling}

Sybyl-X 2.0/Certara and HyperChem 6.0 programs were engaged to conduct the molecular modeling simulations. OpenBabel (inter)change file format converter was employed for data conversion. The crystallographic geometry of carborane cluster was retrieved from Crystallographic Data Centre (deposition code: 1010195) and modified accordingly. The initial compound geometry optimization was performed using the optimized potentials for liquid simulations (OPLS) force field and Polak-Ribiere (conjugate gradient) method implemented in HyperChem 6.0 with a $0.1 \mathrm{kcal} / \mathrm{A}$ mol energy gradient convergence criterion. The specification of the electrostatic potential values based on the partial atomic charges was carried out with the Gasteiger-Hückel method implemented in Sybyl-X. CoMFA modeling efficiency of electronic and steric potentials in the molecular environment is directly controlled by the specification of the atomic superimposition. Hence, one 6-ordered atom trial alignment on the most active molecule 9 according to the active analogue approach (AAA) was used in FIT method to cover the entire bonding topology of naphtalimide ring (pharmacophore hypothesis). The steric and electrostatic potentials were calculated using $\mathrm{sp}^{3}$ carbon probe atom with a charge of +1 . CoMFA grid spacing was $2.0 \AA$ for all the dimensions within the defined region, which extended beyond the van der Waals envelopes of all molecules by at least $4.0 \AA$-for each molecule the energies with a total of 1680 grid points were calculated with $2 \AA$ spacing in a lattice of $14 \times 12 \times 10$, respectively. The potential energies at each lattice point can be plotted as three-dimensional color-coded contour maps indicating the regions where steric hindrance and/or charged substituents enhance or diminish the binding affinity. 


\subsubsection{Similarity-Based Activity Landscape (SALI)}

The numerical sampling of similarity-related structure-activity landscape index (SALI) can be quantitatively expressed according to the following formula:

$$
S A L I_{x, y}=\frac{\left|A_{\mathrm{x}}-A_{\mathrm{y}}\right|}{1-\operatorname{sim}(x, y)}
$$

where $A_{x}$ and $A_{y}$ are the activity profiles for the $x$-th and $y$-th molecule and $\operatorname{sim}(x, y)$ is the pair-wise similarity evaluation $[83,84]$. Tanimoto coefficient was engaged for the fingerprint-based similarity estimation, where the structural pair-wise molecular relatedness is approached using the equation:

$$
T(x, y)=\frac{n_{x y}}{\left(n_{x}+n_{y}-n_{x y}\right)}
$$

where $n_{x y}$ is the number of bits set into 1 shared in the fingerprint of the molecule $x$ and $y$, $n_{x}$ is the number of bits set into 1 in the molecule $x, n_{y}$ is the number of bits set into 1 in the molecule $y$, respectively.

\subsubsection{Principal Component Analysis (PCA) and Partial Least Squares Method (PLS)}

The human-friendly 2D/3D plots of the compound distribution in the experimentalbased (FCS) and virtual-derived (VCS) molecular space might be displayed using the principal component analysis (PCA) method. PCA is a linear projection method, that can be applied to model multivariate data with a relatively small number of so-called principal components (scores and loadings) generated to maximize the description of variance within the input data [85]. The PCA model with $f$ principal components for a data matrix $X$ can be calculated as follows:

$$
X=T P^{T}+E
$$

where $X$ is a data matrix with $m$ objects and $n$ variables, $T$ is the score matrix with dimensions $(m \times f), P^{T}$ is a transposed matrix of loadings with dimensions $(f \times n)$ and $E$ is a matrix of the residual variance $(m \times n)$ not explained by the first $f$ principal components. On the whole, the first few principal components (PCs) frequently describe sufficiently data variance and reveal the groups of objects.

The partial least squares (PLS) approach generates a regression relation between variable $\mathrm{Y}$ and an ensemble of descriptors $\mathrm{X}$ according to the following equation:

$$
\mathrm{Y}=\mathbf{X} b+\mathrm{e}
$$

where $b$ is a vector of the regression coefficients and $e$ is a vector of the errors. The complexity of PLS models was estimated using the leave-one-out cross-validation procedure (LOO-CV) [86]. The dependent variable for each left-out object is calculated based on the model with one, two, three, etc. factors, respectively. A cross-validated leave-one-out $q_{c v}^{2}$ metric for the approximation of the model performance is calculated as follows:

$$
q_{c v}^{2}=1-\frac{\sum_{i}^{m}\left(\text { obs }_{i}-\text { pred }_{i}\right)^{2}}{\sum_{i}^{m}\left(\text { obs }_{i}-\text { mean }\left(o b s_{i}\right)\right)^{2}}
$$

where $o b s$ is the assayed value; pred is the predicted value; mean is the mean value of $o b s$, and $i$ refers to the object index ranging from 1 to $m$. The cross-validated standard error of prediction $s$ is estimated using the equation:

$$
s=\sqrt{\frac{\sum_{i}^{m}\left(o b s_{i}-\text { pred }_{i}\right)^{2}}{m-k-1}}
$$


where $m$ is the number of objects and $k$ is the number of the PLS factors in the model. The quality of external predictions was validated by the standard deviation of error of prediction (SDEP), $q_{\text {test }}^{2}$ and the mean absolute error (MAE) metrics defined as:

$$
\begin{gathered}
\text { SDEP }=\sqrt{\frac{\sum_{i}^{n}\left(\text { pred }_{i}-o b s_{i}\right)^{2}}{n}} \\
q_{\text {test }}^{2}=1-\frac{\sum_{i}^{n}\left(\text { obs }_{i}-\text { pred }_{i}\right)^{2}}{\sum_{i}^{n}\left(\text { obs }_{i}-\text { mean }_{\left.\left(o b s_{i}\right)\right)^{2}}\right.} \\
M A E=\frac{\sum_{i}^{n} \mid \text { pred }_{i}-o b s_{i} \mid}{n}
\end{gathered}
$$

where $n$ is the number of molecules in the test set.

\section{Conclusions}

In this paper, we have described convenient protocols for synthesizing 1,8-naphthalimide derivatives modified with an ortho- or meta-carborane clusters at position 3 of the heteroaromatic skeleton. The X-ray structure of the 1,8-naphthalimide-carborane conjugates 39 and 41 was established. In addition, we determined the cytotoxic activity of the modified conjugates against HepG2 cells and found that modified naphthalimides were significantly more active than modified anhydrides. Conjugates modified with ortho-carboranes were rather more active than those bearing meta-carboranes. The type of linker chain between the carborane cluster and the heterocyclic system influenced the antiproliferative activity of the naphthalimides, and the activity varied as follows: 8-11 (-triazole- linker) $>$ 33-36 (-NH-CH- linker) > 39-42 (-NH-CO- linker) > 17-20 (-O-triazole- linker). Furthermore, our study showed that modified conjugates could effectively induce cell cycle arrest at G0/G1 or G2M phase and activate mainly apoptosis as well as autophagy and ferroptosis which was confirmed using the flow cytometry analysis. Among the studied compounds, conjugate 35 induced ROS production resulting in almost four times higher number of 8-oxo-dG in comparison to mitonafide, and strongly promoted apoptosis which might inhibit the growth of HepG2 cells. However, the presence of the carboranyl cluster at position 3 of these compounds did not promote them as effective Topo II inhibitors.

The DNA binding properties of the synthesized compounds were also investigated by UV-vis, CD, and thermal denaturation experiments. It was found that these compounds were rather weak classical DNA intercalators, which indicated another type of interaction with DNA. The lysosome-targeting behavior of compounds 33, 34, and 36 and their imaging capacity w studied by co-localization experiments, which revealed that these conjugates selectively localized in the lysosomes, which additionally enabled the localization of boron/carborane in the cells.

We assessed the similarity-driven property space for the series of carborane-containing conjugates using PCA. The investigation of the spatial space defined by the first three orthogonal components (PC1-PC3) revealed that carborane-based derivatives are clustered into four subgroups. The projection of the $\mathrm{PIC}_{50}$ values on the PC1 vs. PC2 plane clearly indicated the diagonal separation of the active and nonactive conjugates. Moreover, the enhancement of the planar descriptor-driven projection with response data resulted in a structure-activity landscape that can be regarded as a subtle picture of (dis)allowed structural adjustment(s) potentially valid for molecular activities. Interestingly, the replacement of the anhydride-like fragment with the imide-based motif influenced the molecular potency, as shown by the comparison of the most active $(11,33,8)$ and nonactive $(6,7,15$, 16) compounds, respectively. Finally, we performed a quantitative CoMFA ligand-based study to specify the potentially valid steric and electrostatic features of the pharmacophore pattern. In this case, the bundle of steric bulk was indicated as the privileged feature contributing (un)favorably to the CoMFA model that was validated accordingly. 
The quantitative comparison of the field-based descriptors can lead to a useful picture of the drug-receptor recognition pattern; however, it should be treated as a crude approximation of the underlying biological reality.

The present work demonstrated that new organic and inorganic hybrids can be considered as a novel class of compounds with potential antitumor activities. Studies on the synthesis and biological properties of new naphthalimides bearing modified carborane at position 4 of the naphthalic ring are carried out in our laboratory and will be published soon.

Supplementary Materials: The following are available online at https:/ / www.mdpi.com/1422-006 $7 / 22 / 5 / 2772 /$ s1.

Author Contributions: Conceptualization: A.B.O.; methodology: A.B.O., S.R., D.G.-W., M.O.-P., A.F.-W., M.G.-P., E.W., A.K. (Aleksandra Kowalczyk), P.S., A.B., A.K. (Agnieszka Kiliszek), W.R.; investigation: S.R. (synthesis, purification of chemical compounds, description of syntheses, NMR, MS, IR, HPLC analysis, physicochemical investigations), D.G.-W., M.O.-P., A.F.-W., M.G.-P., E.W. (biological investigations), A.K. (Aleksandra Kowalczyk), P.S. (anti-topoisomerase activity), A.K. (Agnieszka Kiliszek), W.R. (x-ray analysis and parts related to x-ray study), A.B. (SAR-mediated similarity assessment and part related to this study); writing—original draft preparation: A.B.O.; correction of the text: A.B.O., S.R., P.S., D.G.-W., and E.W.; correction after reviews: A.B.O.; supervision: A.B.O.; project administration: A.B.O.; funding acquisition: A.B.O. All authors have read and agreed to the published version of the manuscript.

Funding: This study was supported by the National Science Centre, Poland, Grant No. 2014/14/E/ ST5/00577.

Institutional Review Board Statement: Not applicable.

Informed Consent Statement: Not applicable.

Data Availability Statement: Not applicable.

Conflicts of Interest: The authors declare no conflict of interest.

\section{References}

1. Kamal, A.; Bolla, N.R.; Srikanth, P.S.; Sirvastava, A.K. Naphthalimide derivatives with therapeutic characteristics: A patent review. Expert Opin. Ther. Pat. 2013, 23, 299-317. [CrossRef]

2. Shen, K.; Sun, L.; Zhang, H.; Xu, Y.; Qian, X.; Lu, Y.; Li, Q.; Ni, L.; Liu, J. A ROS-mediated lysosomal-mitochondrial pathways is induced by a novel amonafide analogue, 7c, in human HeLa cervix carcinoma cells. Cancer Lett. 2013, 333, 229-238. [CrossRef] [PubMed]

3. Shao, J.; Li, Y.; Wang, Z.; Xiao, M.; Yin, P.; Lu, Y.; Qian, X.; Xu, Y.; Liu, J. 7b, a novel naphthalimide derivative, exhibited antiinflammatory effects via targeted-inhibiting TAK-1 following down-regulation of ERK1/2- and p38 MAPK-mediated activation of NF-kB in LPS-stimulated RAW264.7 macrophages. Int. Immunopharmacol. 2013, 17, 216-228. [CrossRef] [PubMed]

4. Pain, A.; Samanta, S.; Dutta, S.; Saxena, A.K.; Shanmugavel, M.; Kampasi, H.; Quazi, G.N.; Sanyula, U. Synthesis and evaluation of substituted naphthalimide nitrogen mustards as rationally designed anticancer compound. Acta Pol. Pharm. 2003, 60, 285-291. [PubMed]

5. Jia, T.; Fu, C.; Huang, C.; Yang, H.; Jia, N. Highly sensitive naphthalimide-based fluorescence polarization probe for detecting cancer cells. ACS Appl. Mater. Inter. 2015, 7, 10013-10021. [CrossRef]

6. Xu, Z.; Ren, Y.Y.; Fan, X.; Cheng, S.; Xu, Q.; Xu, L. A naphthalimide-based fluorescent probe for highly selective detection of pyrophosphate in aqueous solution and living cells. Tetrahedron 2015, 71, 5055-5058. [CrossRef]

7. Lee, Y.H.; Tang, Y.; Verwilst, P.; Lin, W.; Kim, J.S. A biotin-guided formaldehyde sensor selectively detecting endogenous concentrations in cancerous cells and tissues. Chem. Commun. 2016, 52, 11247-11250. [CrossRef]

8. Zhang, L.; Su, F.; Kong, X.; Lee, F.; Sher, S.; Day, K.; Tian, Y.; Meldrum, D.R. 1,8-Nahphtalimide derivative dyes targeting live cell mitochondria with large stokes shift. ChemBioChem 2016, 17, 1719-1724. [CrossRef]

9. Tomczyk, M.D.; Walczak, K.Z. 1,8-Naphthalimide based DNA intercalators and anticancer agents. A systematic review from 2007 to 2017. Eur. J. Med. Chem. 2018, 159, 393-422. [CrossRef]

10. Tandon, R.; Luxami, V.; Kaur, H.; Tandon, N.K. Paul, 1,8-Naphthalimide: A potent DNA intercalator and target for cancer therapy. Chem. Rec. 2017, 17, 1-39. [CrossRef]

11. Wang, K.-R.; Qian, F.; Sun, Q.; Ma, C.-I.; Rong, R.-X.; Cao, Z.-R.; Wang, X.-M.; Li, X.-L. Substituents effects on cytotoxic activity, spectroscopic property, and DNA binding property of naphthalimide derivatives. Chem. Biol. Drug Des. 2016, 87, 664-672. [CrossRef] 
12. Scholz, M.; Hey-Hawkins, E. Carbaboranes as pharmacophores: Properties, synthesis and application strategies. Chem. Rev. 2011, 111, 7035-7062. [CrossRef]

13. Issa, F.; Kassiou, M.; Rendina, L.M. Boron in drug discovery: Carboranes as unique pharmacophores in biologically active compounds. Chem. Rev. 2011, 111, 5701-5722. [CrossRef]

14. Leśnikowski, Z.J. Challenges and opportunities for the application of boron clusters in drug design. J. Med. Chem. 2016, 59, 7738-7758. [CrossRef]

15. Leśnikowski, Z.J. Recent developments with boron as a platform for novel drug design. Expert Opin. Drug Dis. 2016, 11, 569-578. [CrossRef] [PubMed]

16. Goszczyński, T.M.; Fink, K.; Boratyński, J. Icosahedral boron clusters as modifying entities for biomolecules. Expert Opin. Drug Dis. 2018, 18, 205-213. [CrossRef]

17. Hey-Hawkins, E.; Vinas Teixidor, C. Boron-based Compounds: Potential and Emerging Applications in Medicine, 1st ed.; John Wiley \& Sons Ltd: Hoboken, NJ, USA, 2018.

18. Ali, F.; Hosmane, N.S.; Zhu, Y. Boron chemistry for medical applications. Molecules 2020, 25, 828. [CrossRef] [PubMed]

19. Leśnikowski, Z.J. What are the current challenges with the application of boron clusters to drug design. Expert Opin. Drug Dis. 2020. [CrossRef]

20. Nekvinda, J.; Różycka, D.; Rykowski, S.; Wyszko, E.; Fedoruk-Wyszomirska, A.; Gurda, D.; Orlicka-Płocka, M.; Giel-Pietraszuk, M.; Kiliszek, A.; Rypniewski, W.; et al. Synthesis of naphthalimide-carborane and metallacarborane conjugates: Anticancer activity, DNA binding ability. Bioorg. Chem. 2020, 94, 103432. [CrossRef] [PubMed]

21. Meldal, M.; Tornoe, C.W. Cu-catalyzed azide-alkyne cycloaddition. Chem. Rev. 2008, 108, 2952-3015. [CrossRef] [PubMed]

22. Nwe, K.; Brechbiel, M.W. Growing applications of "click chemistry" for bioconjugation in contemporary biomedical research. Cancer Biother. Radio. 2009, 24, 289-302.

23. Matuszewski, M.; Kiliszek, A.; Rypniewski, W.; Lesnikowski, Z.J.; Olejniczak, A.B. Nucleoside bearing clusters and their phosphoramidites-building blocks for modified oligonucleotide synthesis. New. J. Chem. 2015, 39, 1202-1221. [CrossRef]

24. Chan, T.R.; Hilgraf, R.; Sharpless, K.B.; Fokin, V.V. Polytriazoles as Copper(I)-stabilizing ligands in calatysis. Org. Lett. 2004, 6, 2853-2855. [CrossRef] [PubMed]

25. Afanasyev, O.I.; Kuchuk, E.; Usanov, D.L.; Chusov, D. Reductive amination in the synthesis of pharmaceuticals. Chem. Rev. 2019, 119, 11857-11911. [CrossRef] [PubMed]

26. Wang, J.; Yang, L.; Houa, C.; Cao, H. A new N-imidazolyl-1,8-naphthalimide based fluorescence sensor for fluoride detection. Org. Biomol. Chem. 2012, 10, 6271-6274. [CrossRef]

27. Brana, M.F.; Castellano, J.M.; Roldan, C.M.; Santos, A.; Vazquez, D.; Jimenez, A. Synthesis and mode(s) of action of a new series of imide derivatives of 3-nitro-1,8-naphthalic. Cancer Chemoth. Pharm. 1980, 4, 61-66. [CrossRef] [PubMed]

28. Dozzo, P.; Kasar, R.A.; Kahl, S.B. Simple, High-yield methods for the synthesis of aldehydes directly from o-, m--, and p-carborane and their further conversions. Inorg. Chem. 2005, 44, 8053-8057. [CrossRef]

29. Bae, J.W.; Lee, S.H.; Jung, Y.J.; Yoon, C.-O.M.; Yoon, C.M. Reduction of ketones to alcohols using a decaborane/pyrrolidine/cerium(III) chloride system in methanol. Tetrahedron Lett. 2001, 42, 2137-2139. [CrossRef]

30. Bae, J.W.; Lee, S.H.; Cho, Y.J.; Yoon, C.M. A reductive amination of carbonyls with amines using decaborane in methanol. J. Chem. Soc. Perkin Trans. 2000, 1, 145-146. [CrossRef]

31. Lee, S.H.; Park, Y.J.; Yoon, C.M. Reductive etherification of aromatic aldehydes with decaborane. Tetrahedron Lett. 1999, 40, 6049-6050. [CrossRef]

32. Bae, J.W.; Jung, Y.J.; Lee, S.H.; Yoon, C.-O.M.; Yoon, C.M. A one-pot synthesis of N-alkylaminobenzenes from nitroaromatics: Reduction followed by reductive amination of using $\mathrm{B}_{10} \mathrm{H}_{14}$. Chem. Commun. 2000, 19, 1857-1858. [CrossRef]

33. Brown, D.G.; Boström, J. Analysis of past and present synthetic methodologies on medicinal chemistry: Where have all the new reaction gone? J. Med. Chem. 2016, 59, 4443-4458. [CrossRef]

34. Malmquist, J.; Sjöberg, S. Asymmetric Synthesis of p-Carboranylalanine (p-Car) and 2-Methyl-o-Carboranylalanine (Me-o-Car). Tetrahedron 1996, 52, 9207-9218. [CrossRef]

35. Naeslund, C.; Ghirmai, S.; Sjöberg, S. Enantioselective synthesis of m-carboranylalanine, a boron rich analogue of phenylalanine. Tetrahedron 2005, 61, 1181-1186. [CrossRef]

36. Różycka, D.; Leśnikowski, Z.J.; Olejniczak, A.B. Synthesis of boron cluster analogs of penicillin and their antibacterial activity. J. Organomet. Chem. 2019, 881, 19-24. [CrossRef]

37. Różycka, D.; Korycka-Machała, M.; Żaczek, A.; Dziadek, J.; Gurda, D.; Orlicka-Płocka, M.; Wyszko, E.; Biniek-Antosiak, K.; Rypniewski, W.; Olejniczak, A.B. Novel isoniazid-carborane hybrids active in vitro against Mycobacterium Tuberculosis. Pharm. Basel 2020, 13, 465.

38. Hardie, M.J.; Raston, C.L. Crystalline hydrogen bonded complexes of o-carborane. CrystEngComm 2001, 3, 162-164. [CrossRef]

39. Mosmann, T. Rapid colorimetric assay for cellular growth and survival: Application to proliferation and cytotoxicity assays. $J$. Immunol. Methods 1983, 65, 55-63. [CrossRef]

40. Berg, K.; Hansen, M.B.; Nielsen, S.E. A new sensitive bioassay for precise quantification of interferon activity as measured via the mitochondrial dehydrogenase function in cells (MTT-method). APMIS 1990, 98, 156-162. [CrossRef] [PubMed]

41. Ji, L.; Yang, S.; Li, S.; Liu, S.; Tang, S.; Liu, Z.; Meng, X.; Yu, S. A novel triazolonaphthalimide induces apoptosis and inhibits tumor growth by targeting DNA and DNA-associated processes. Oncotarget 2017, 8, 37394-37408. [CrossRef] 
42. Park, J.M.; Shin, Y.J.; Riew, T.R.; Lee, M.Y. The indilinone MAZ51 induces cell rounding and G2M cell cycle arrest in glioma cells without the inhibition of VEGFR-3 phoshorylation: Involvment of the RhoA and Akt/GSK3beta signaling pathways. PLoS ONE 2014, 9, e109055.

43. Kasai, H.; Nishimura, S. Hydroxylation of deoxyguanosine at the C-8 position by ascorbic acid and other reducing agents. Nucleic Acids Res. 1984, 12, 2137-2145. [CrossRef]

44. D'Arcy, M.S. Cell death: A review of the major forms of apoptosis, necrosis and autophagy. Cell Biol. Int. 2019, 43, 582-592. [CrossRef]

45. Xie, S.Q.; Li, Q.; Zhang, Y.H.; Wang, J.H.; Mei, Z.H.; Zhao, J.; Wang, C.J. NPC-16, a novel naphthalimide-polyamine conjugate, induced apoptosis and autophagy in human hepatoma HepG2 cells and Bel-7402 cells. Apoptosis 2011, 16, 27-34. [CrossRef] [PubMed]

46. Ling, J.; Kim, S.G.; Blenis, J. Rapamycin: One drug, many effects. Cell Metab. 2014, 19, 373-379.

47. Li, M.; Yang, Z.; Vollmer, L.L.; Gao, Y.; Fu, Y.; Liu, C.; Chen, X.; Liu, P.; Vogt, A.; Yin, X.M. AMDE-1 is a dual function chemical for autophagy activation and inhibition. PLoS ONE 2015, 10, e0122083. [CrossRef] [PubMed]

48. Li, J.; Cao, F.; Yin, H.; Huang, Z.; Lin, Z.; Mao, N.; Sun, B.; Wang, G. Ferroptosis: Past, present and future. Cell Death Dis. 2020, 11, 888. [CrossRef] [PubMed]

49. Bonam, S.R.; Wang, F.; Muller, S. Lysosomes as a therapeutic target. Nat. Rev. Drug Discov. 2019, 18, 923-948. [CrossRef] [PubMed]

50. Luo, W.; Jiang, H.; Tang, X.; Liu, W. A reversible ratiometric two-photon lysosome-targeted probe for real-time monitoring of pH changes in living cells. J. Mater. Chem. B 2017, 5, 4768-4773. [CrossRef] [PubMed]

51. Chen, Z.; Liang, X.; Zhang, H.; Xie, H.; Liu, J.; Xu, Y.; Zhu, W.; Wang, Y.; Wang, X.; Tan, S.; et al. A new class of naphthalimidebased antitumor agents that inhibit Topoisomarese II and induce lysosomal membrane permeabilization and apoptosis. J. Med. Chem. 2010, 53, 2589-2600. [CrossRef] [PubMed]

52. Rong, R.-X.; Wang, S.-S.; Liu, X.; Li, R.-F.; Wang, K.-R.; Cao, Z.-R.; Li, X.-L. Lysosomes-targeting imaging and anitcancer properties of novel bis-naphthalimide derivatives. Bioorg. Med. Chem. Lett. 2018, 28, 742-747. [CrossRef]

53. Tomczyk, M.D.; Byczek-Wyrostek, A.; Strama, K.; Wawszków, M.; Kasprzycki, P.; Walczak, K.Z. Anticancer activity and Topoisomerase II inhibition of naphthalimides with $\omega$-Hydroxylalkylamine Side-Chains of Different Lengths. Med. Chem. 2019, 15, 550-560. [CrossRef] [PubMed]

54. Ferguson, L.R.; Baguley, B.C. Topoisomerase II enzymes and mutagenicity. Environ. Mol. Mutagen. 1994, 24, 245-261. [CrossRef]

55. Wijeratne, S.S.; Patel, J.M.; Kiang, C.H. Melting Transitions of DNA-Capped Gold Nanoparticle Assemblies; Springer: New York, NY, USA, 2012; pp. 269-282.

56. Mergny, J.L.; Duval-Valentin, G.; Nguyen, C.H.; Perrouault, L.; Faucon, B.; Rougee, M.; Montenay Garestier, T.; Bisagni, E.; Helene, C. Triple helix-specific ligands. Science 1992, 256, 1681-1684. [CrossRef]

57. Lenglet, G.; David-Cordonnier, M.-H. DNA-destabilizing agents as an alternative approach for targeting DNA: Mechanism of action and cellular consequence. J. Nucleic. Acids 2010. [CrossRef]

58. Lesnik, E.A.; Guinosso, C.J.; Kawasaka, A.M.; Sasmor, H.; Zounes, M.; Cummins, L.L.; Ecker, D.J.; Cook, P.D.; Freier, S.M. Oligonucleotides containing 2'-O-modified adenosine: Synthesis and effects on stability of DNA:RNA duplex. Biochem. US 1993, 32, 7832-7838. [CrossRef] [PubMed]

59. Ivanov, V.I.; Minchenkova, L.E.; Schyolkina, A.K.; Poletayev, A.I. Different conformations of double-stranded nucleic acids in solution as revealed by circular dichroism. Biopolymers 1973, 12, 89-110. [CrossRef] [PubMed]

60. Jiang, H.; Shang, L.; Wang, Z.X.; Dong, S.J. Spectrometric and voltammetric investigation of interaction of neutral red with calf thymus DNA: pH effect. Biophys. Chem. 2005, 118, 42-50. [CrossRef] [PubMed]

61. Mati, S.S.; Roy, S.S.; Chall, S.; Bhattacharya, S.; Bhattacharya, S.C. Unveiling the groove binding mechanism of a biocompatible naphthalimide-based organoselenocyanate with calf thymus DNA: An "ex vivo" fluorescence imaging application appended by biophysical experiments and molecular docking simulations. J. Phys. Chem. B 2013, 117, 14655-16665. [CrossRef]

62. Vardevanyan, P.O.; Antonyan, A.P.; Parsadanyan, M.A.; Davtyan, H.G.; Karapetyan, A.T. The binding of ethidium bromide with DNA: Interaction with single- and double-stranded structures. Exp. Mol. Med. 2003, 35, 527-533. [CrossRef]

63. Peltason, L.; Bajorath, J. Systematic computational analysis of structure-activity relationships: Concepts, challenges and recent advances. Future Med. Chem. 2009, 1, 451-466. [CrossRef]

64. Bak, A.; Pizova, H.; Kozik, V.; Vorcakova, K.; Kos, J.; Treml, J.; Odehnalova, K.; Oravec, M.; Imramovsky, A.; Bobal, P.; et al. SAR-mediated similarity assessment of the property profile for new, silicon-based AChE/BChE inhibitors. Int. J. Mol. Sci. 2019, 20, 5385. [CrossRef] [PubMed]

65. Colquhoun, D. The quantitative analysis of drug-receptor interactions: A short history. Trends Pharmacol. Sci. 2006, 27, 149-157. [CrossRef]

66. Bak, A.; Kozik, V.; Malik, I.; Jampilek, J.; Smolinski, A. Probability-driven 3D pharmacophore mapping of antimycobacterial potential of hybrid molecules combining phenylcarbamoyloxy and N-arylpiperazine fragments. SAR QSAR Environ. Res. 2018, 29, 801-821. [CrossRef] [PubMed]

67. Grammatica, P. Principles of QSAR models validation: Internal and external. Qsar Comb. Sci. 2007, 26, 694-701. [CrossRef]

68. Bak, A.; Kozik, V.; Smolinski, A.; Jampilek, J. Multidimensional (3D/4D-QSAR) probability-guided pharmacophore mapping: Investigation of activity profile for a series of drug absorption promoters. RSC Adv. 2016, 6, 76183-76205. [CrossRef]

69. Maggiora, G.M.; Shanmugasundaram, V. Molecular similarity measures. Methods Mol. Biol. 2011, 672, 39-100. 
70. Lopez-Lopez, E.; Prieto-Martínez, F.D.; Medina-Franco, J.L. Activity landscape and molecular modeling to explore the SAR of dual epigenetic inhibitors: A focus on G9a and DNMT1. Molecules 2018, 23, 3282. [CrossRef]

71. Gieleciak, R.; Magdziarz, T.; Bak, A.; Polanski, J. Modeling robust QSAR. 1. Coding molecules in 3D-QSAR-from a point to surface sectors and molecular volumes. J. Chem. Inf. Model. 2005, 45, 1447-1455. [CrossRef]

72. Polanski, J.; Bak, A.; Gieleciak, R.; Magdziarz, T. Modeling robust QSAR. J. Chem. Inf. Model. 2003, 46, 2310-2318. [CrossRef]

73. Golbraikh, A.; Tropsha, A. Beware of q2! J. Mol. Graph. Mod. 2002, 20, 269-276. [CrossRef]

74. Kabsch, W. XDS. Acta Crystallogr. D Biol. Crystallogr. 2010, 66, 125-132. [CrossRef]

75. Sheldrick, G.M. SHELXT-Integrated space-group and crystal-structure determination. Acta Crystallogr. A 2015, A71, 3-8. [CrossRef]

76. Sheldrick, G.M. A short history of SHELX. Acta Crystallogr. A 2008, 64, 112-122. [CrossRef]

77. Dolomanov, O.V.; Bourhis, L.J.; Gildea, R.J.; Howard, J.A.K.; Puschmann, H. OLEX2: A complete structure solution, refinement and analysis program. J. App. Crystallogr. 2009, 42, 339-341. [CrossRef]

78. Quintana-Espinoza, P.; García-Luis, J.; Amesty, Á.; Martín-Rodríguez, P.; Lorenzo-Castrillejo, I.; Ravelo, A.G.; FernándezPérez, L.; Machín, F.; Estévez-Braun, A. Synthesis and study of antiproliferative, antitopoisomerase II, DNA-intercalating and DNA-damaging activities of arylnaphthalimides. Bioorgan. Med. Chem. 2013, 21, 6484-6495. [CrossRef] [PubMed]

79. Tsukamoto, K.; Shimabukuro, S.; Mabuchi, M.; Maeda, H. A Naphthalimide-based Cd ${ }^{2+}$ fluorescent probe with carbamoylmethyl groups working as chelators and PET-promoters under neutral conditions. Chem. Eur. J. 2016, 22, 8579-8585. [CrossRef]

80. Barciszewska, A.-M.; Giel-Pietraszuk, M.; Perrigue, P.M.; Naskręt-Barciszewska, M. Total DNA methylation changes reflect random oxidative DNA damage in gliomas. Cells 2019, 8, 1065. [CrossRef] [PubMed]

81. Egawa, Y.; Hayashida, R.; Seki, T.; Anzai, J. Fluorometric determination of heparyn based on self-quenching of fluorescein-labeled protamine. Talanta 2008, 76, 736-741. [CrossRef] [PubMed]

82. Nie, M.Y.; Wang, Y.; Li, H.L. Electrochemical and spectral properties of phenylhydrazine in the presence of ß-cyclodextrin. Pol. J. Chem. 1997, 71, 816-822.

83. Bajorath, J.; Peltason, L.; Wawer, M.; Guha, R.; Lajiness, M.S.; Van Drie, J.H. Navigating structure-activity landscapes. Drug Discov. Today 2009, 14, 698-705. [CrossRef]

84. Guha, R.; Van Drie, J.H. Assessing how well a modeling protocol captures a structure-activity landscape. J. Chem. Inf. Model. 2008, 48, 1716-1728. [CrossRef] [PubMed]

85. Bender, A.; Scheiber, J.; Jenkins, J.L.; Sukuru, S.C. How similar are similarity searching methods? A principal component analysis of molecular descriptor space. J. Chem. Inf. Model. 2009, 49, 108-119. [CrossRef] [PubMed]

86. Bak, A.; Polanski, J. Modeling robust QSAR 3: SOM-4D-QSAR with iterative variable elimination IVE-PLS: Application to steroid, azo dye, and benzoic acid series. J. Chem. Inf. Model. 2007, 47, 1469-1480. [CrossRef] [PubMed] 